المجلة الدولية للدراسات التربوية والنفسية

$$
\text { بحث رقم } 9
$$

\title{
مشكلات البيئة الصَّفية التي تواجه طالبات جامعة طيبة وعلاقتها بمستوى الرضا العام عن المناخ الدراسي الجامعي
}

\author{
حباة رشبيد حمزة العمري \\ أستاذ مناهج وطرق تدريس اللغة الإنجليزية المشارك- كلية التربية \\ جامعة طيبة- السعودية \\ hayatalamri@hotmail.com
}

قبول البحث: 2020/8/1

مراجعة البحث: 7//22 - م 2020

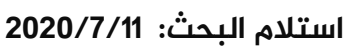

DOI: https://doi.org/10.31559/EPS2021.9.2.9 


\title{
مشكلات البيئة الصَّفية التي تواجه طالبات جامعة طيبة وعلاقتها بمستوى الرضـا العام عن المناخ الدراسي الجـامعي
}

\author{
حياة رشيد حمزة العمري \\ أستاذ مناهج وطرق تدريس اللغة الإنجليزية المشارك- كلية التربية- جامعة طيبة- السعودية حئية \\ hayatalamri@hotmail.com
}

DOI: https://doi.org/10.31559/EPS2021.9.2.9 2020/7/11 2020/8/1 مراجعة البحث: 2020/22 قبول البحث البحث: 201/20

\begin{abstract}
هدفت الدراسة إلى التَّعرُف على أبرز مشكلات البيئة الصَّفية الجامعية التي تواجه طالبات جامعة طيبة، وإيجاد الفروق بين متوسطات درجات مستوى الرضا العام عن المناخ الدراسي الجامعي التي تُعزى إلى تلك المشكلات، إضيافة إلى أهم التَّوصيات والمشئه

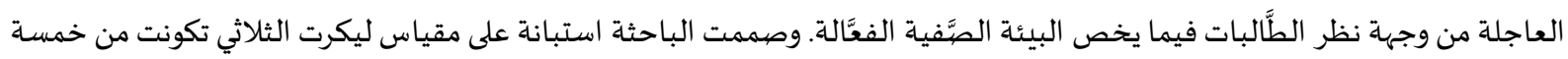

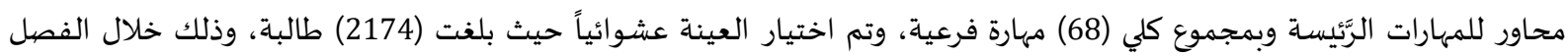

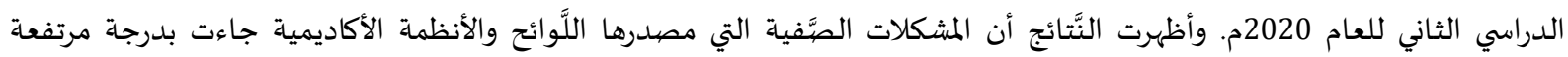

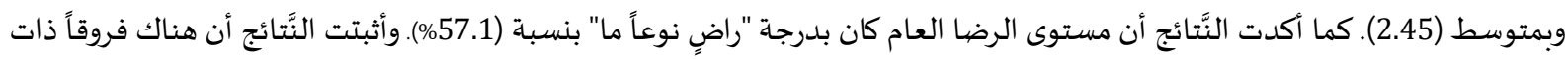
دلالة إحصائية عند مستوى (0.05) بين متوسطات درجات مستوى الرضا العام ومصادر مشكلات البيئة الصَّفية الجامعية، لصالح الأستاذ

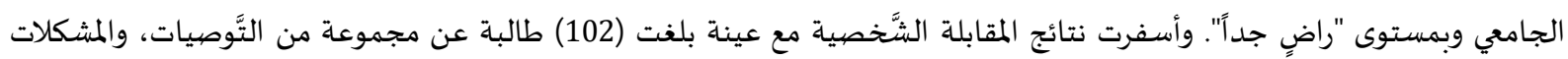

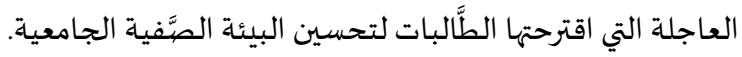
الكلمات المفتاحية: مشكلات البيئة الصيَّفية؛ مستوى الرضا؛ المناخ الدراسي الجامعي.
\end{abstract}

أولت الحكومات المختلفة أهميّة كبيرة للمرحلة الجامعيّة؛ لأهها بوابة لمرحلة مهمة في حياة المتعلم، فهي التي تحدّد مساره في الحياة، ودوره في

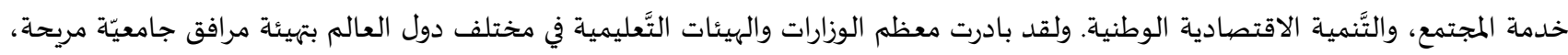

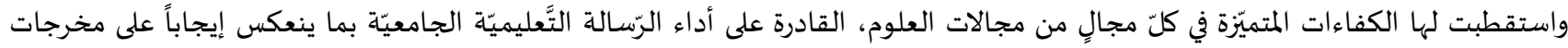

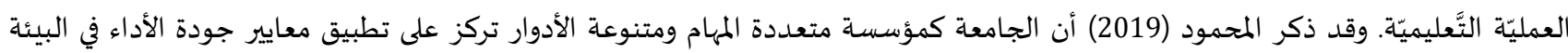

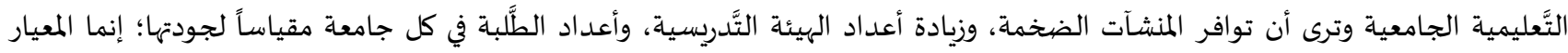

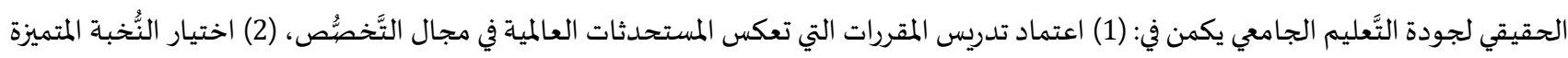

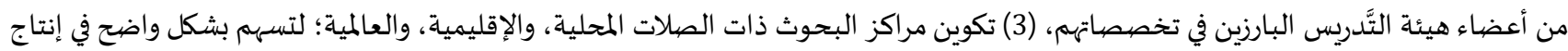

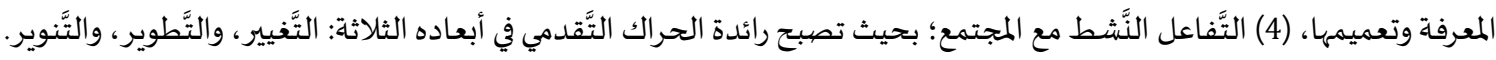

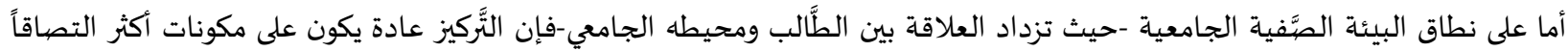

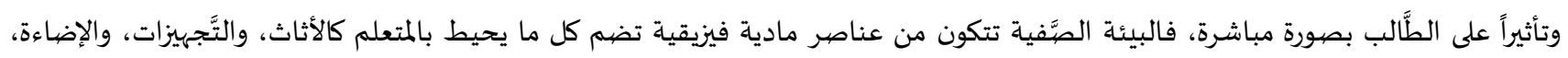

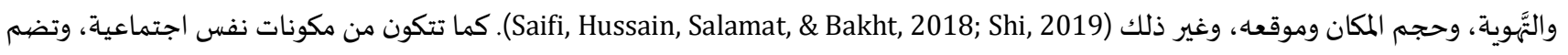

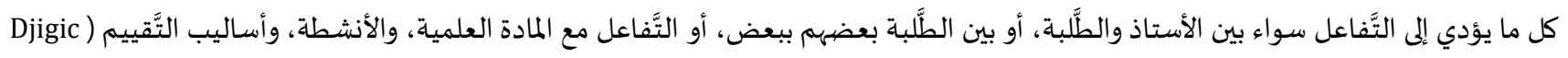




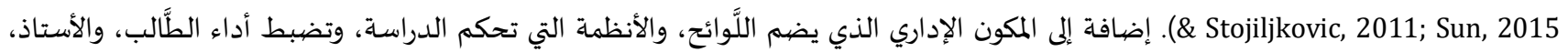

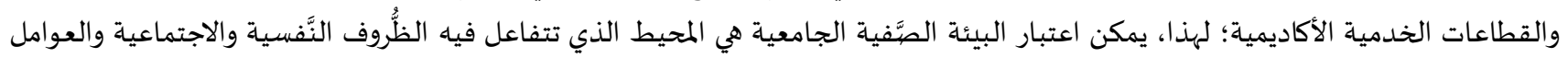

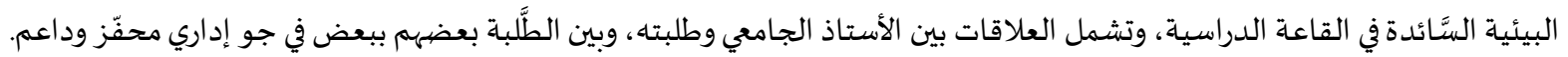

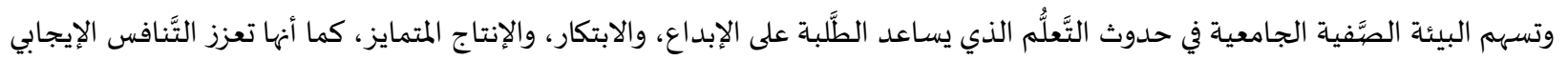

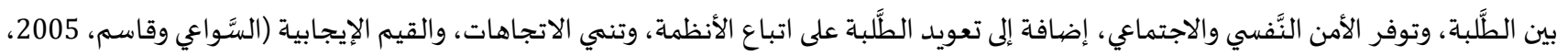

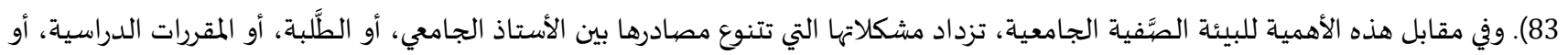

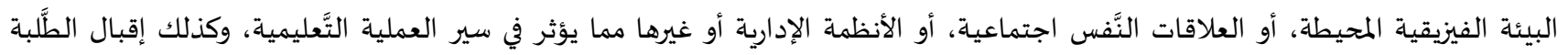

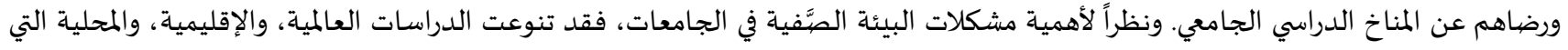

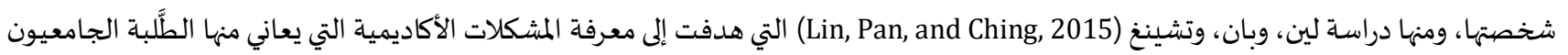

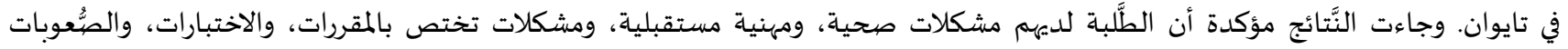

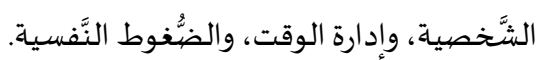

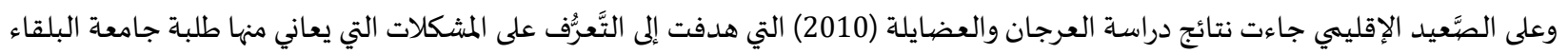

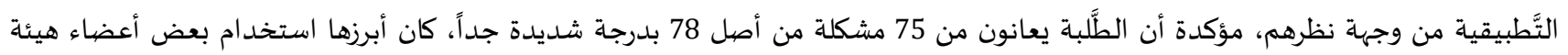

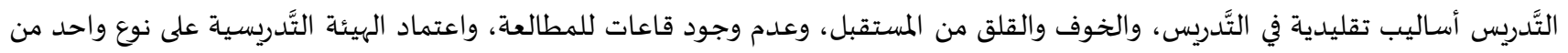

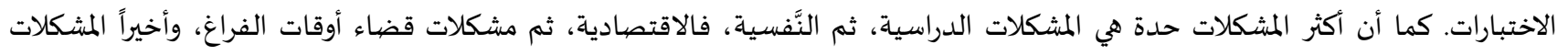

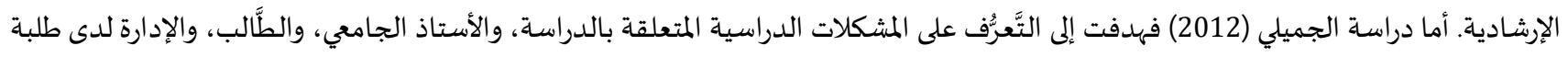

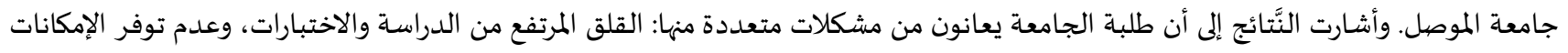

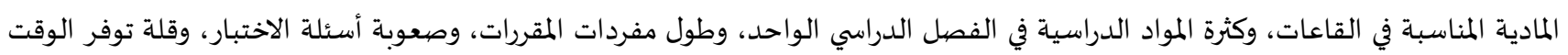

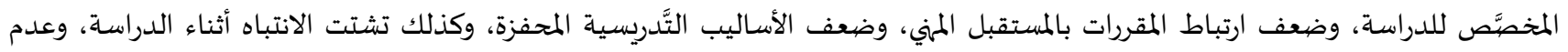

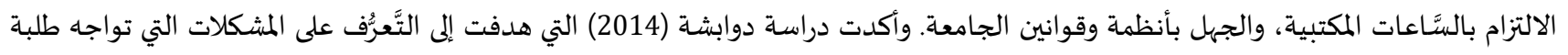

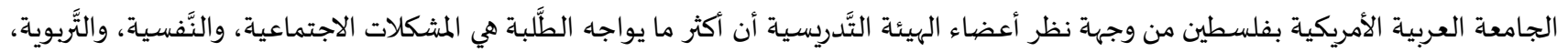

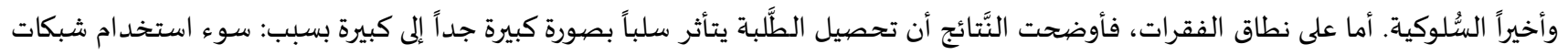

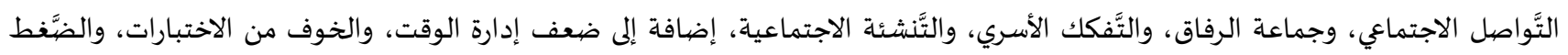

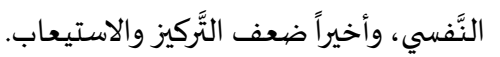

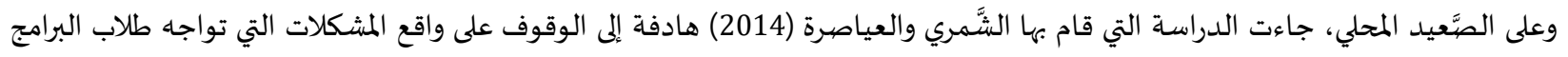

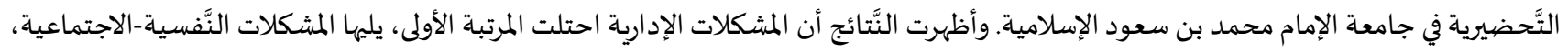

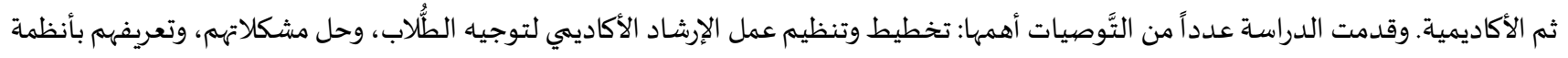

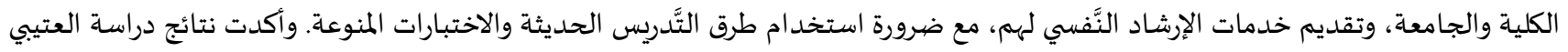

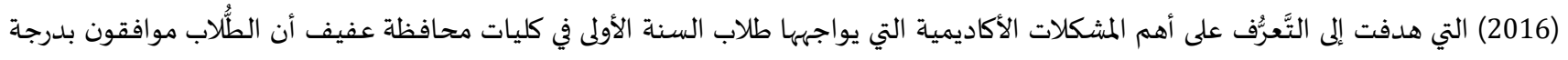

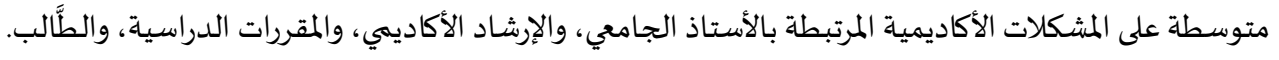

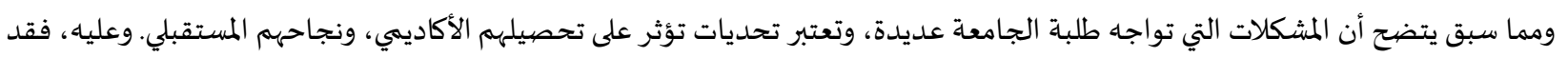

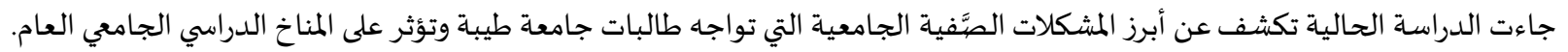

مشكلة الدراسة:

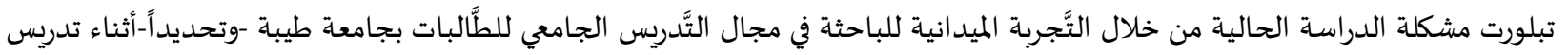

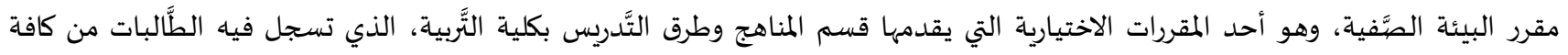

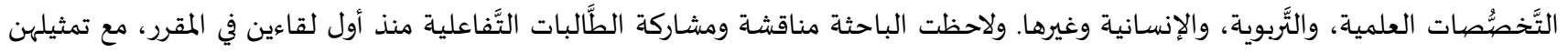

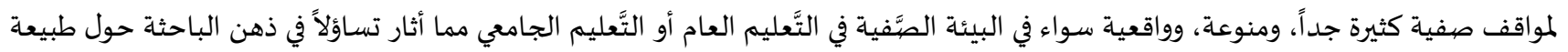

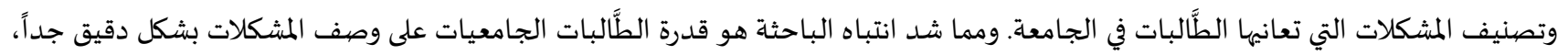

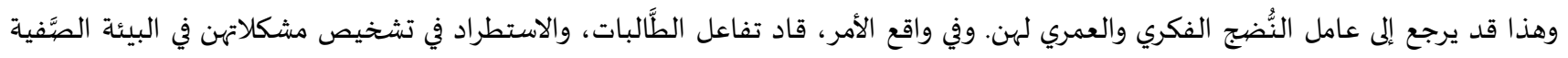

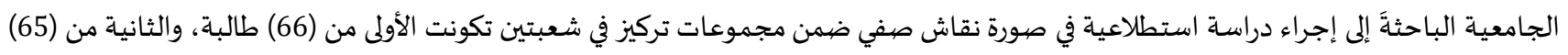


طالبة من مختلف التَّخصُُصات. وصهمت الباحثة قائمة بأهم مشكلات البيئة الصَّفية الجامعية، وطرحتها للنقاش بغية الحصول على آراء الطُّالبات فهها من حيث أهميتها، ومدى توافرها، مع رصديد آني لردود أفعال الطُّالبات حوالها.

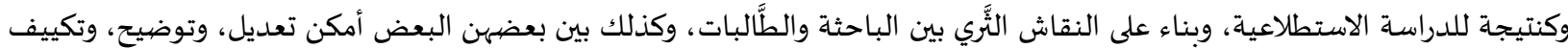

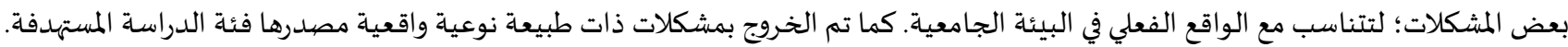

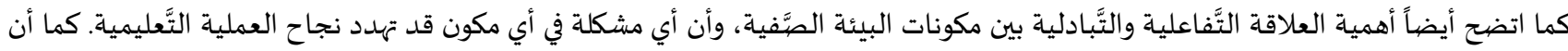

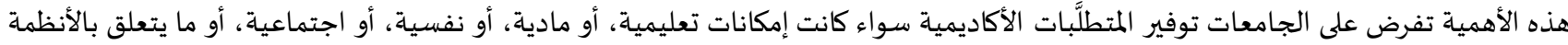

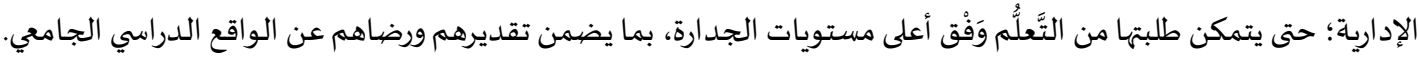

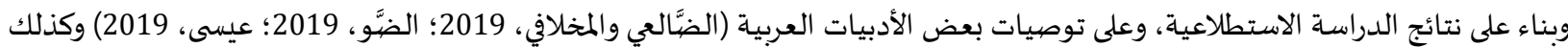

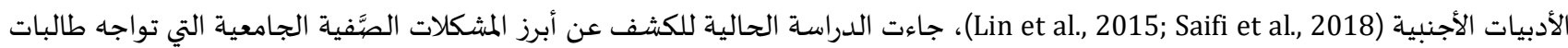

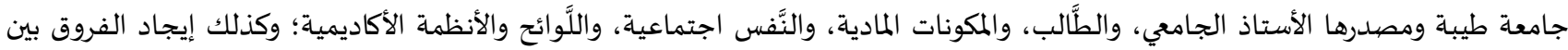

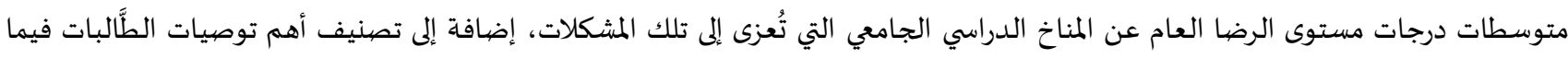
يخص البيئة الصَّفية الفعَّالة، وأبرز المشكلات التي ينبغي إعادة النَّظر فهيا.

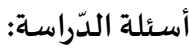

في ضوء طبيعة مشكلة الدراسة، تسعى الدراسة للإجابة عن الأسئلة الآتية:

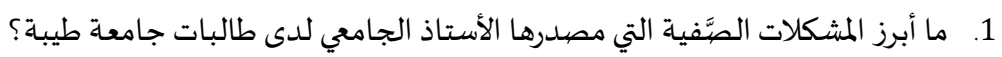

2.

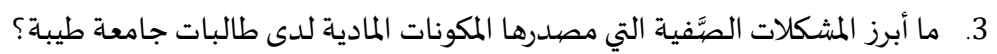

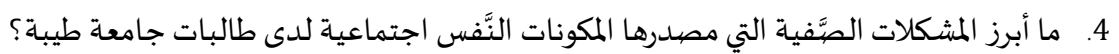

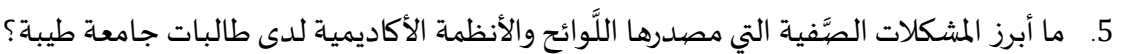

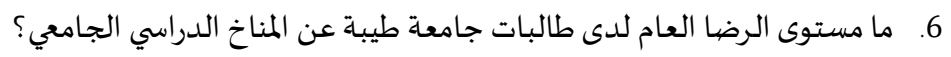

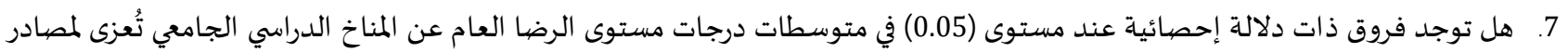

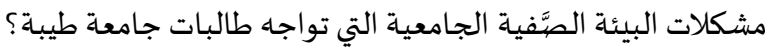
8. ما أبرز التَّوصيات والمشكلات التي ترغب طالبات جامعة طيبة في طرحها للنَّظر فيها من قبل إدارة الجامعة والهيئة التَّدريسية؟

فرض الدّراسة: 1. لا توجد فروق ذات دلالة إحصائية عند مستوى (0.05) في متوسطات درجات مستوى الرضا العام عن المناخ الدراسي الجامعي تُعزى إلى مصادر

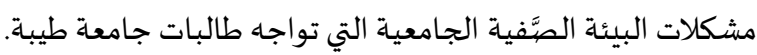

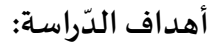
1. الوقوف على أبرز المشكلات الصَّفية التي مصدرها الأستاذ الجامعي، والطَّلب، والمككونات المادية، والنَّفس اجتماعية، واللَّوائح والأنظمة الأكاديمية

لدى طالبات جامعة طيبة. 2. تواجه طالبات جامعة طيبة؟ 3. تصنيف أهم توصيات طالبات جامعة طيبة فيما يخص البيئة الصَّفية الفعَّالة، وأبرز المشكلات التي ينبغي إعادة النَّظر فهها.

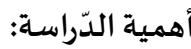
1. الأهمية النَّرية: تسعى الدراسة الحالية إلى معرفة أهم وأبرز المشكلات الصيَّفية الجامعية التي تعاني منها طالبات جامعة طيبة، وعلاقها

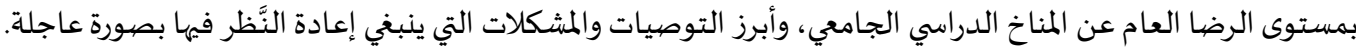

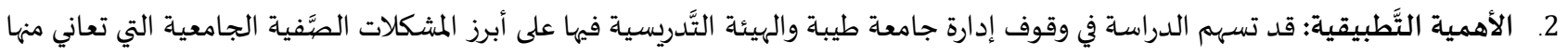

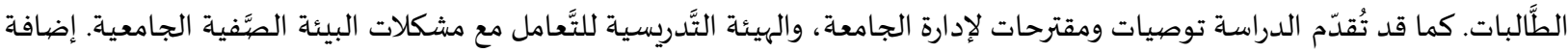

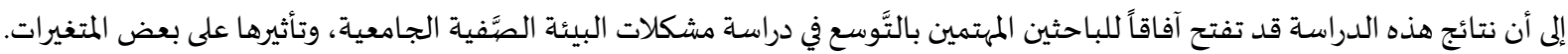




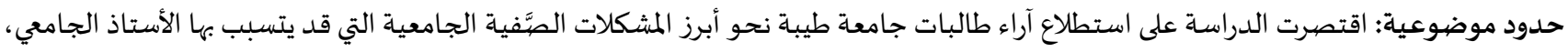

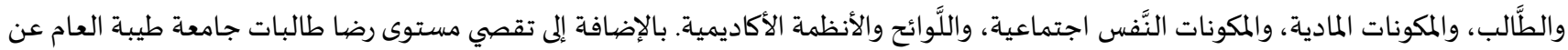

المناخ الدراسي الجامعي من خلال تطبيق استبانة ومقابلة شخصية. حدود مكانية: اقتصرت الدراسة على طالبات جامعة طيبة بالمدينة المنورة فقط المطان.

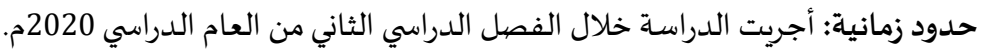

مصبطلحات الدّراسة: البيئة الصيَّفية التَّعليمية: عرفها شحاتة والنَّجار (2003: 87) بأنها "تشمل الوسط المحيط بأي نظام تعليمي من: أبنية تعليمية، وأثاث، وتجهيزات

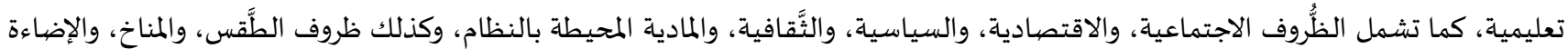

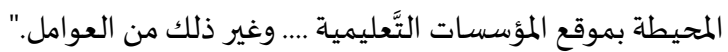

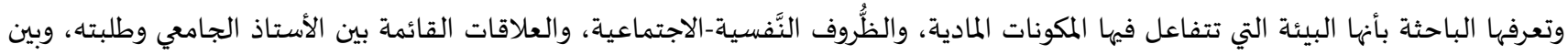

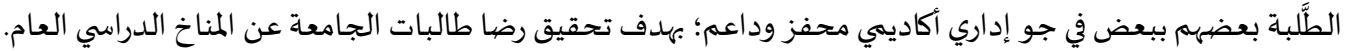

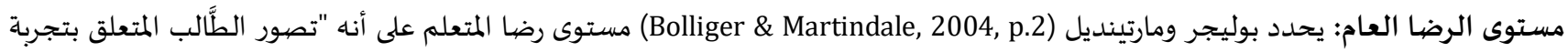

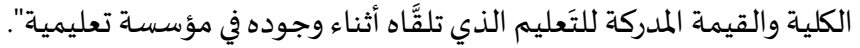

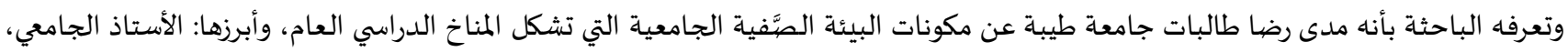

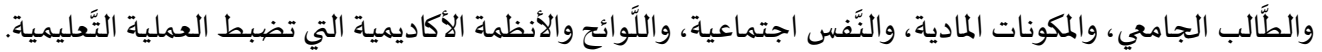

الإطار النَّظري: يغطي الإطار النَّظري محورين: واقع مشكلات البيئة الصَّفية الجامعية، ومستويات الرضا عن المناخ الدراسي والجامعي.

المحور الأول: و اقع مشكلات البيئة الصيَّفية الجامعية:

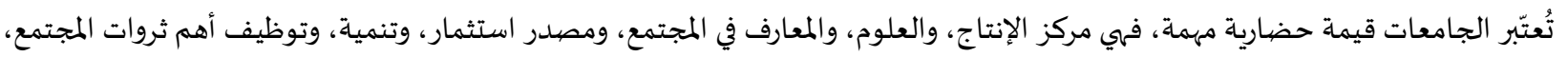
وهي التَّروة البشرية،، فالتَّقدم من صناعتها، ورجال الفكر من نتاجها (تمام وعفيفي، 2009). وقد أكَّد العيدروس (2012) أن الاهتمام بتطوير بيئة

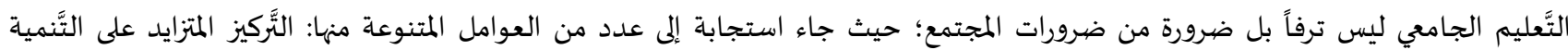

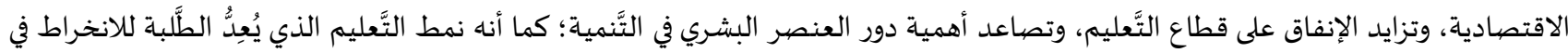

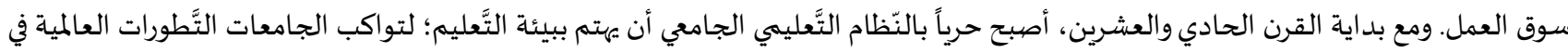

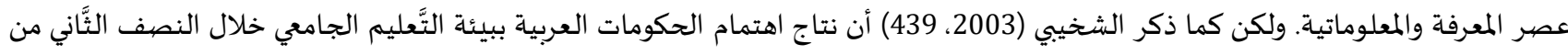

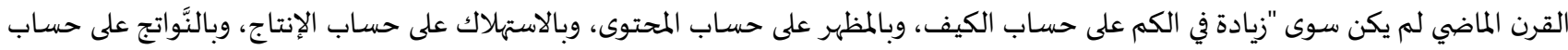

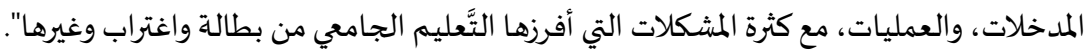

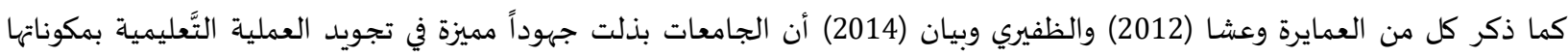

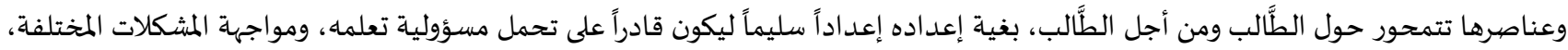

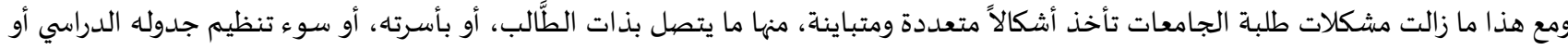

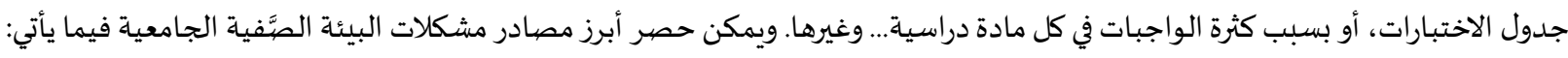

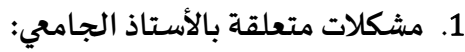

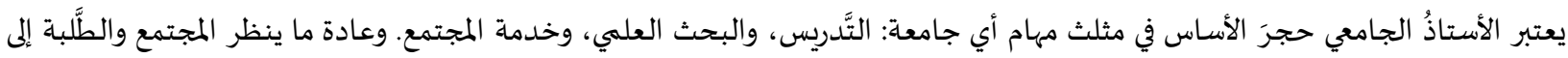

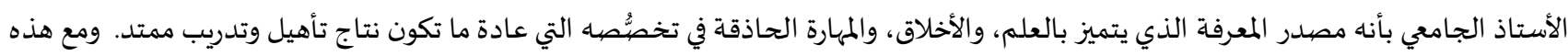

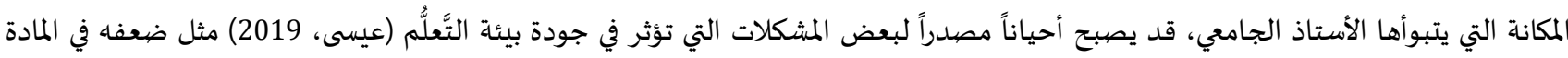

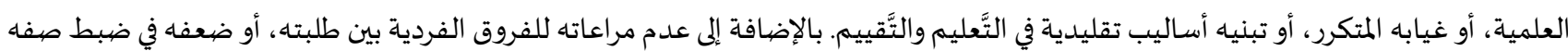

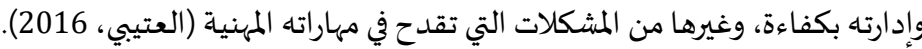

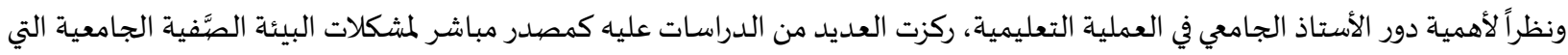

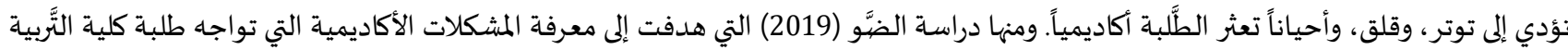

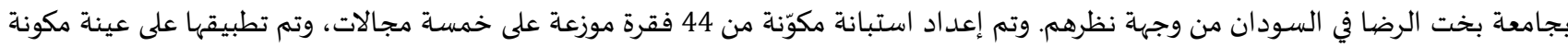


من(90) طالباً وطالبة. وأكدت النَّتائج أن أهم المشكلات التي تواجه الطُّلبة هي مجال الكلية والإدارة، والمقررات الدراسية، والطُّلبة، والأساتذة،

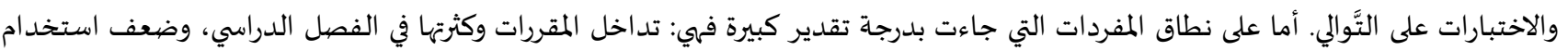

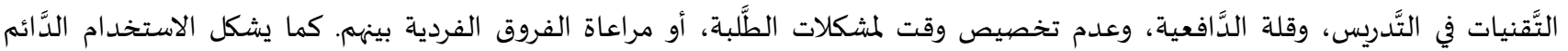

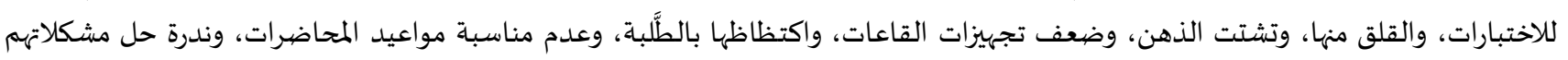

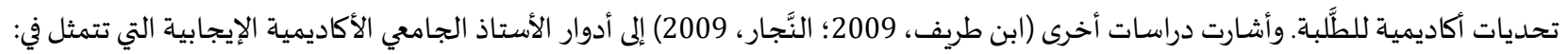
تطبيق الأستاذ الجامعي مداخل تدريسية فعَّالة. توظيف التَّقنية ودمجها في التَّعليم بكفاءة وفاعلية. التََّّامل مع كل ما يؤثر في الأمن النَّفي والاجتماعي للطُّلَّة.

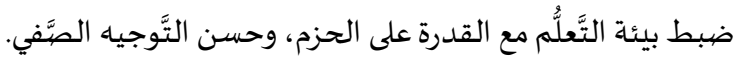

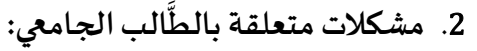

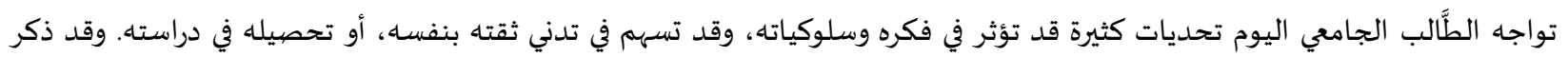

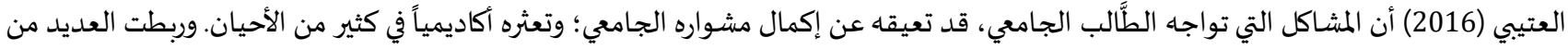

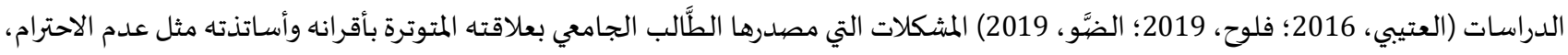

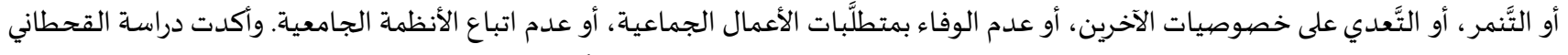

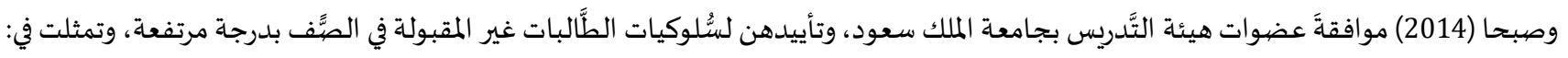

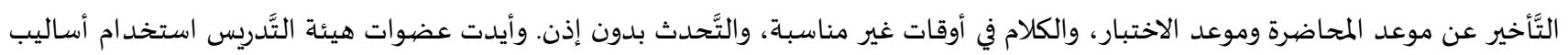
الانضباط الوقائية أكثر من الدَّاعمة أو التَّصحيحية. لهذا ركزت بعض الدراسات مثل دراسة ابن طريف (2009)، وكذلك دراسة الشَّمري والعياصرة (2014) على مجمهوعة من التََّّصيات للطُّلبة

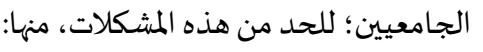
تكوين علاقات بناءة مع الأقران داخل الصيَّف وخارجها. • تحمل المسؤولية الفردية تجاه العمل الجماعي والتَّاوني.

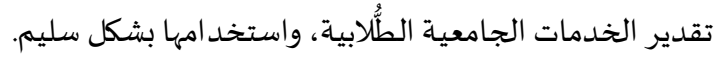
بذل الجهد للتَّكيف والانسجام مع الواقع البيئي الأكاديمي وتقبله.

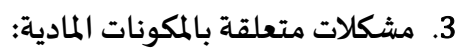

يواجه الطَّالب الجامعي وأعضاء الهيئة التدريسية صعوبات مصددرها البيئة الفيزيقية التي تحيط بالعملية التَّعليمية، مثل ازدحام الطُّلاب في

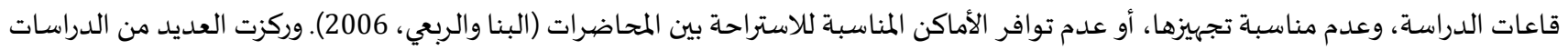

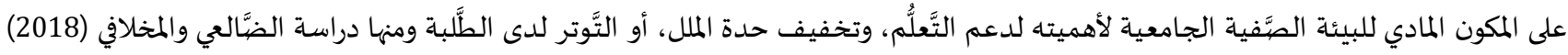

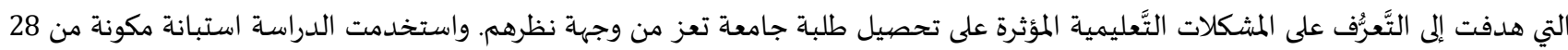

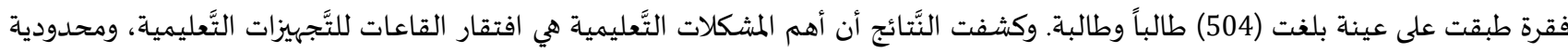

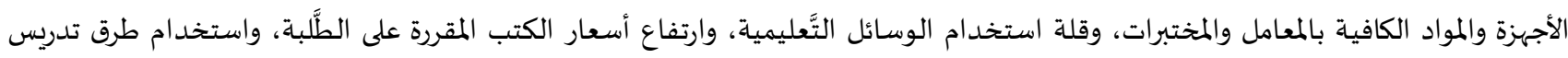

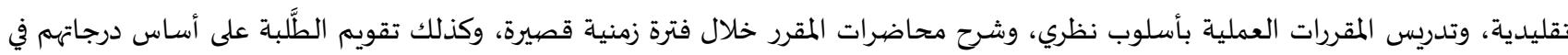

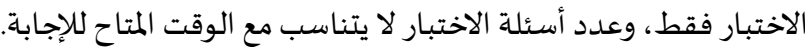

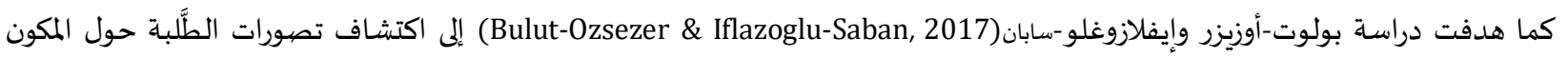

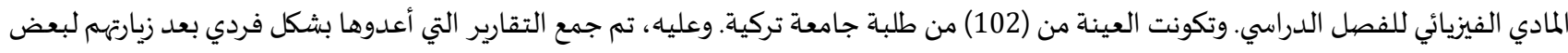

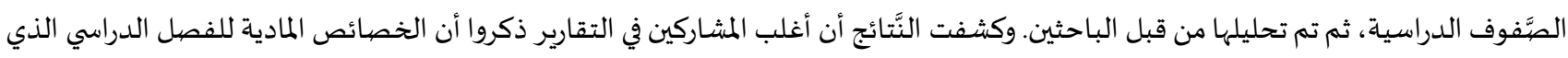

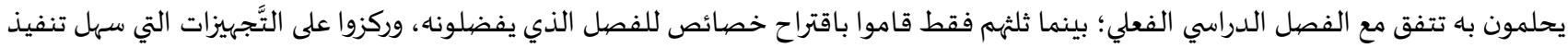

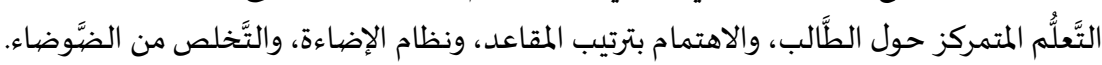

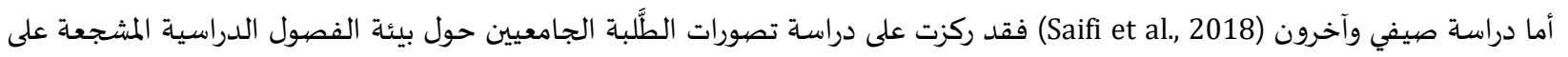

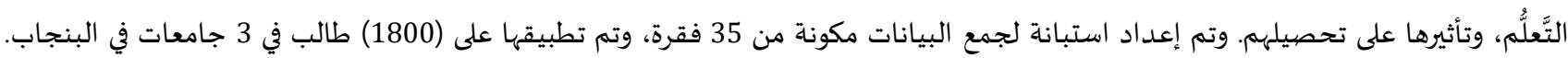

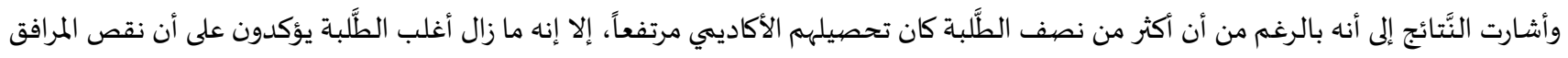


المادية يمثل مشكلة كبيرة لهم. ولهذا أوصت الدراسة بضرورة تزويد الفصول الدراسية بالمرافق المادية، وأهمها التَّقنيات التَّعليمية، إضافة إلى أهمية

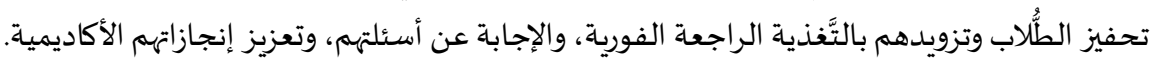

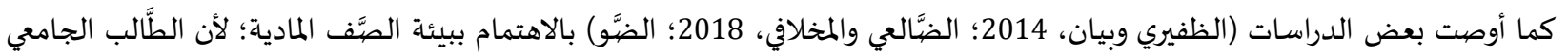
يقضي فيها عدداً كبيراً من السـاعات تتزايد وتتنوع خلالها احتياجاته؛ لهذا، ينبغي اهتمام الجامعات بالتَّالي: تزويد الفصول الدراسية بالمتطلَّبات المادية الأساسية اللازمة لسير العملية التَّعليمية. توفير أماكن مخصيَّصة للراحة، وقضياءوقت الفراغ ومجهزة بما ييسر التَّعلُّم.

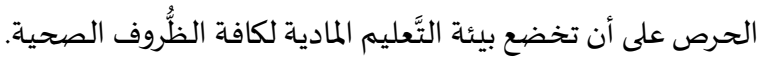

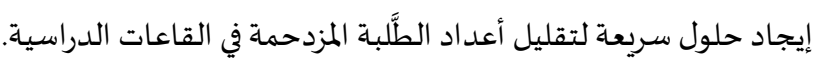
4. مشكلات متعلقة بالمكونات النَّفس اجتماعية:

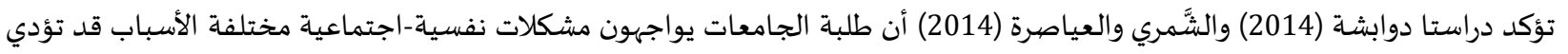

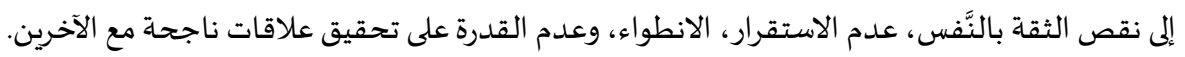

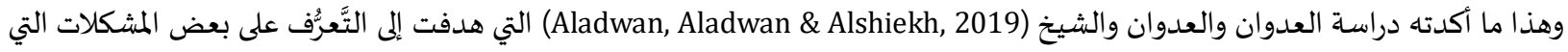

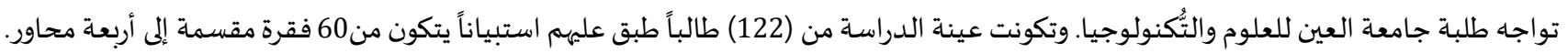

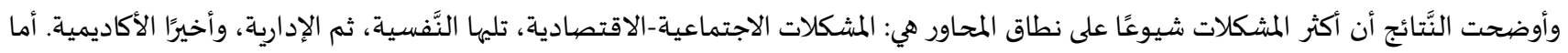

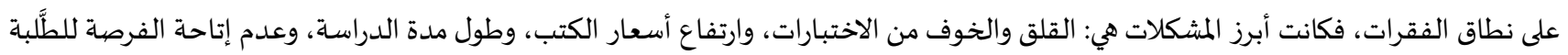

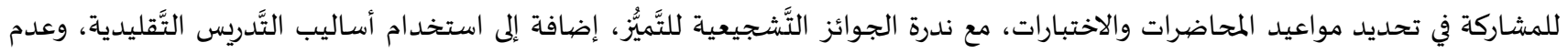

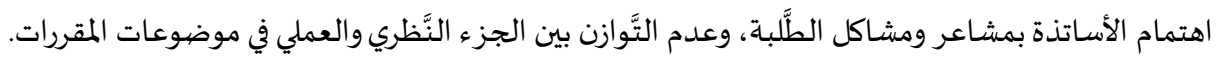

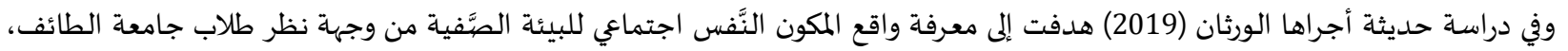

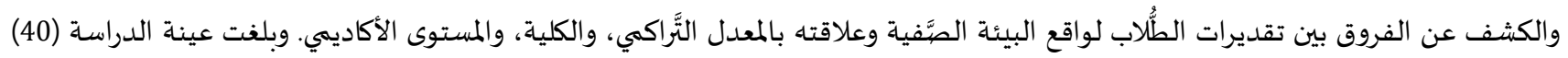

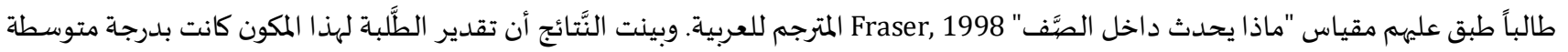

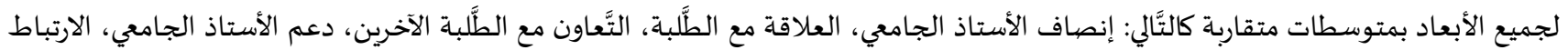

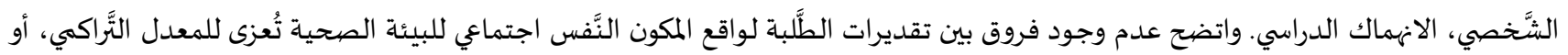

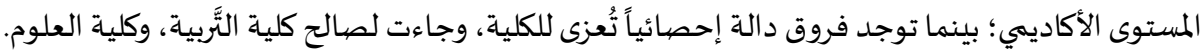
كما قدمت دراسة لين وآخرون (Lin et al., 2015)، وصيفي وآخرون (Saifi et al., 2018)، وأيضاً العدوان وآخرون (Aladwan et al., 2019) توصيات للحد من المشكلات النَّفس اجتماعية مثل: إتاحة الفرصة للطُّلبة للمشاركة في تحديد أوقات المحاضرات والاختبارات الدورية والنهائية. تحفيز الطَّلبة من خلال الفعاليات والأنشطة، مع تقديم الجوائز التَّشجيعية للمتميزين.

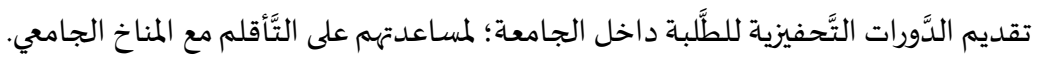
الاهتمام بالمشاكل الاجتماعية والنَّفسية التي يعاني منها الطُّلبة، وتقصّي مصيادرها.

5. مشكلات متعلقة باللَّو ائح، والأنظمة الأكاديمية:

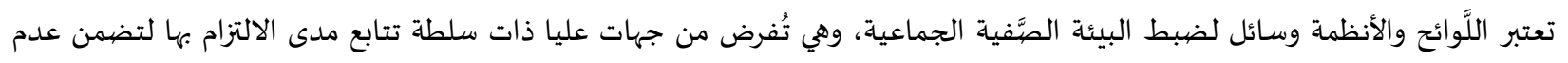
تخطيها. وفي هذا السياق، يظهر الدَّور الفاعل لها في الانضباط، وحفظ النظام، والحقوق. وقد يتسبب أي خلل أو تعثر في تطبيقها في حدوث مشكلات

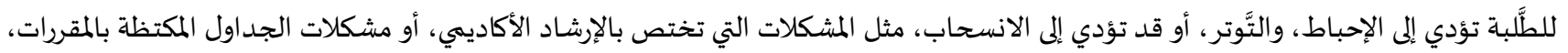

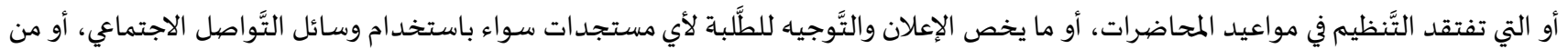
خلال لقاءات دورية مع الطَّلبة. وتناولت دراسة فلوح (2019) التي هدفت إلى معرفة الواقع الدراسي للطَّالب الجامعي من وجهاة نظر طلبة معهد العلوم الاجتماعية بالمركز

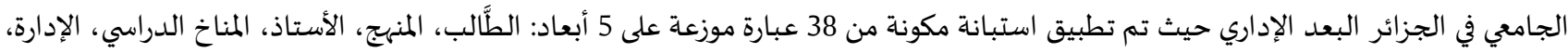

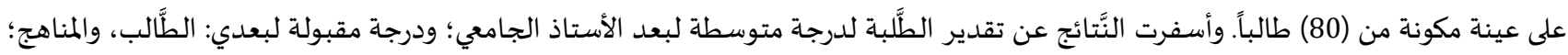

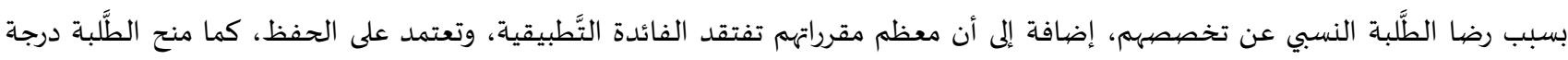

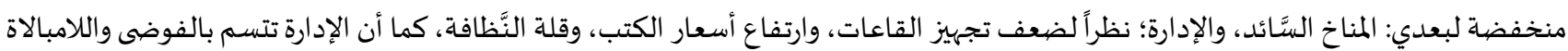
بمشكلات الطَّلبة. 
وقد قدمت دراسات مثل البنا والربعي (2006) والنَّجار (2009)، والجميلي (2012)، وكذلك الظفيري وبيان (2014) توصيات للتَّخفيف من

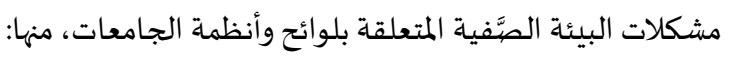

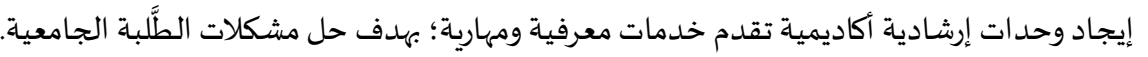

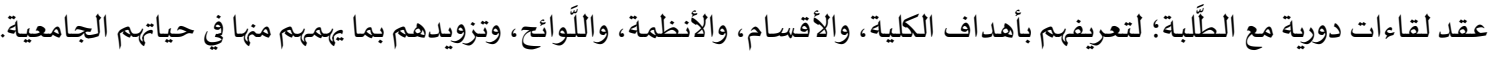
تكوين شبكة تواصل فاعلة مع طلبة الجامعة؛ للإعلان عن جميع الفعاليات، والأنشطة، والمسابقات داخل وخارج الجامعة.

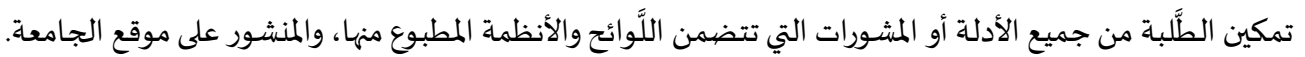

\section{المحور الثاني: رضا الطَّالب الجامعي عن الو اقع الدراسي:}

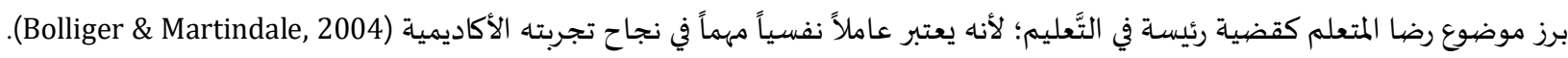

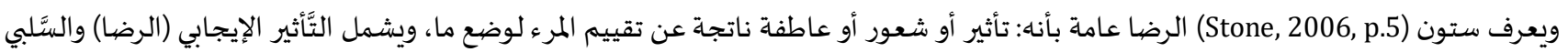

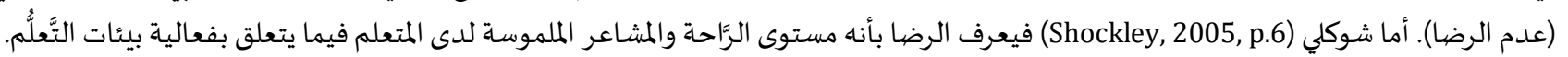

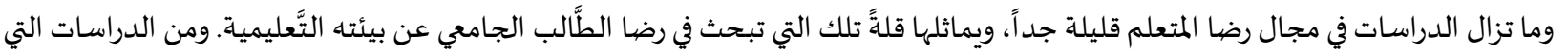
ركزت على رضا الطالب الجامعي دراسة صوالحة والعمري (2013) التي هدفت إلى معرفة أهمية الحاجات الأكاديمية من وجهة نظر (365) من طلبة الكالبة

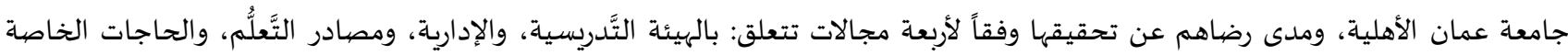

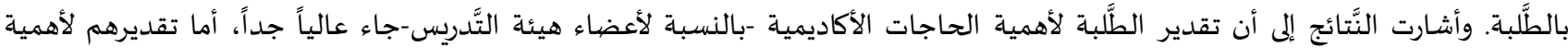

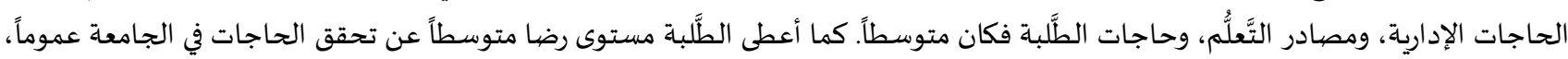

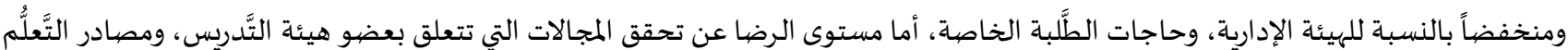
فكان متوسطاً.

أما دراسة القضاة وخليفات (2013) فقد هدفت إلى تقصي درجة رضا طلبة جامعة مؤتة عن الخدمات الجامعية. وأظهرت نتائج تحليل الاستبانة

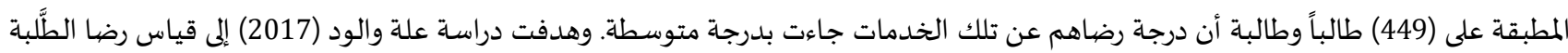

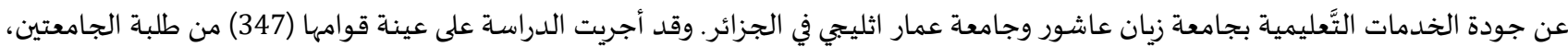

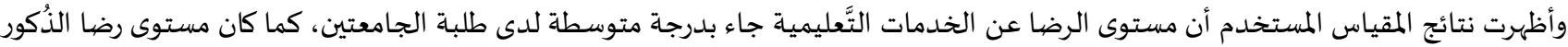
أعلى من الإناث في الجامعتين أيضاً. أما دراسة فلوح وعبيدي (2019) فقد هدفت إلى التَّعرُف على مدى رضا الطُّلَبة عن الخدمات الجامعية التي تقدم إليهم في الإقامات الجامعية.

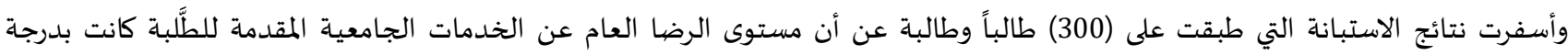

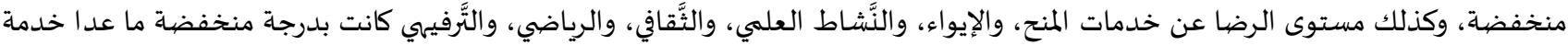

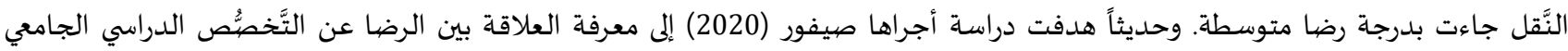

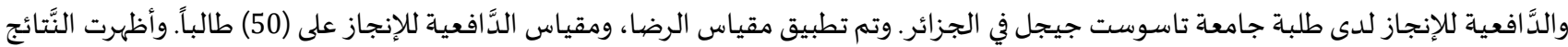

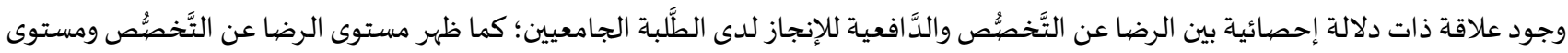

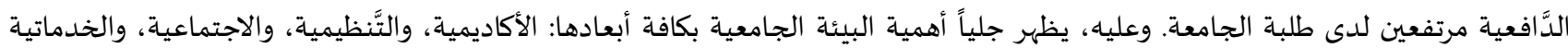

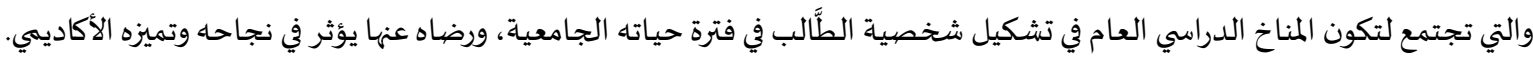

\section{منهج الدّراسة وإجراءاءها:}

استخدمت الدّراسة المنهج الوصفي للوقوف على أبرز المشكلات الصيَّفية الجامعية التي تواجه طالبات جامعة طيبة ومصهدرها: الأستاذ الجامعي، والطَّالب، والمككونات المادية، والنَّفس اجتماعية، واللَّائح والأنظمة الأكاديمية.

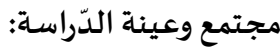

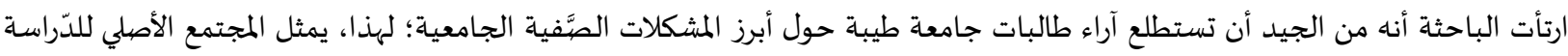

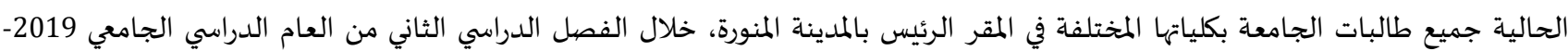

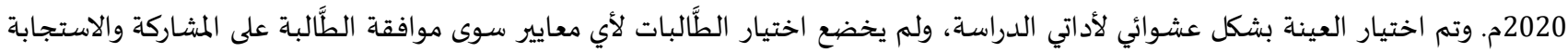

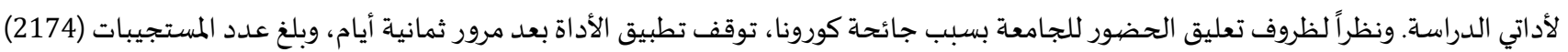
طالبة تم اعتبارها عينة الدراسة، أما المقابلة الشخصية فقد بلغ عدد الطُالبات اللاتي وافقن على المشاركة (102) طالبة. 


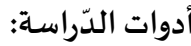

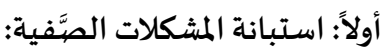

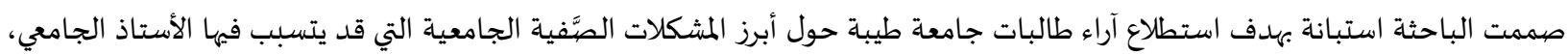

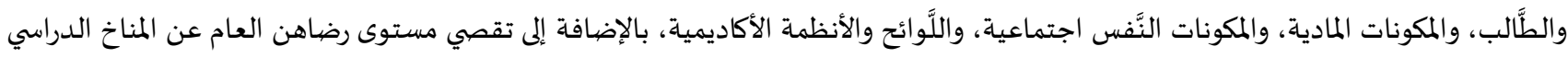

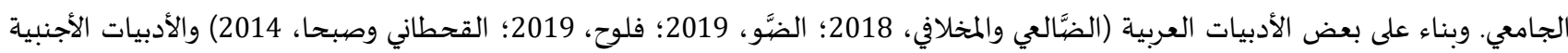
(Aladwan et al., 2019; Djigic \& Stojiljkovic, 2011)، فقد صممت الباحثة قائمة بالمشكلات وناقشتها مع شعبة تضم (66) طالبة، وأخرى تضمي

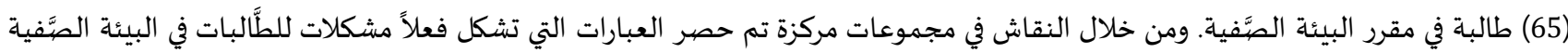

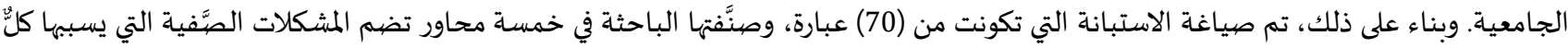

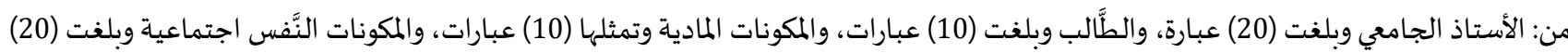
عبارة، واللَّوائح والأنظمة الأكاديمية وكانت (10) عبارات.

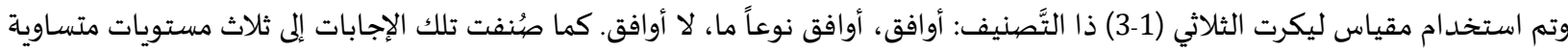

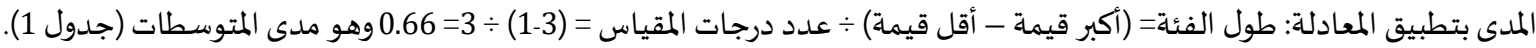

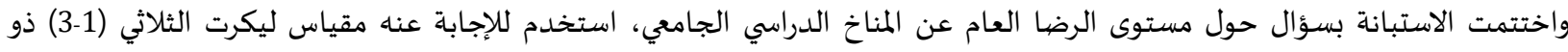
التَّصنيف: راضٍ جداً، راضٍ نوعاً ما، غير راضٍ مطلقاً.

\begin{tabular}{|c|c|c|c|}
\hline لأوافق=1 & أوافق نوعاً ما= & أوافق=3 & الوصف \\
\hline $1-1.66$ & $1.67-2.33$ & $2.34 \cdot 3$ & مدى المتوسطات \\
\hline منخفضة & متوسطة & مرتفعة & رجة التقدير \\
\hline
\end{tabular}

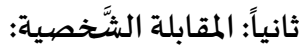

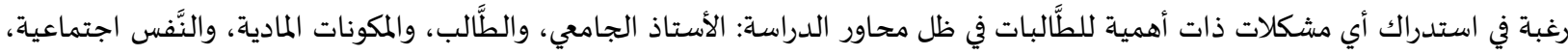

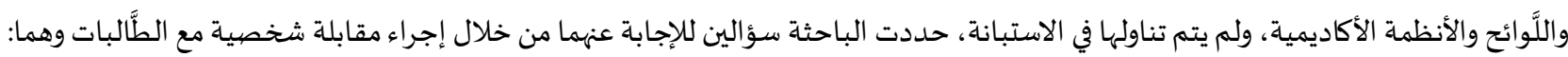
1.

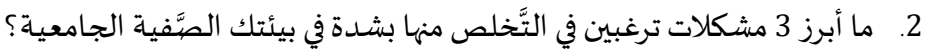

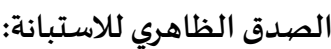

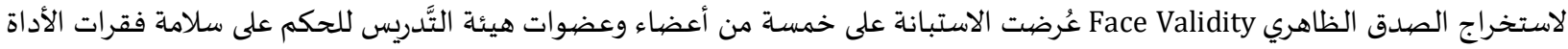

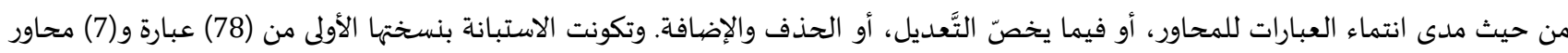

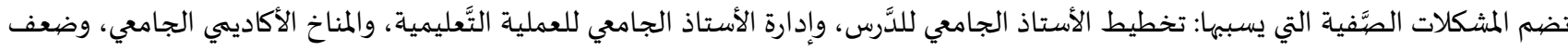

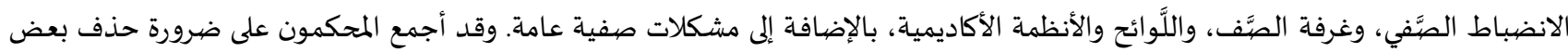

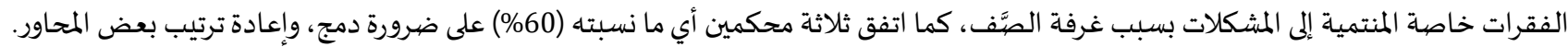

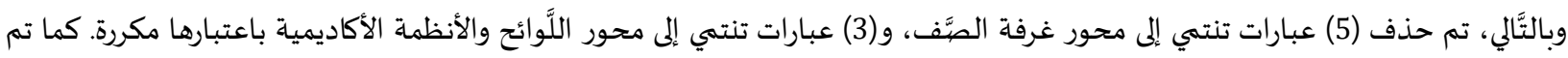

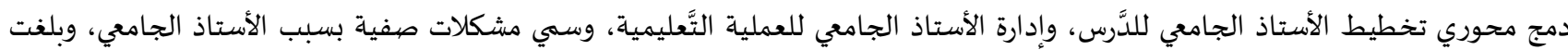

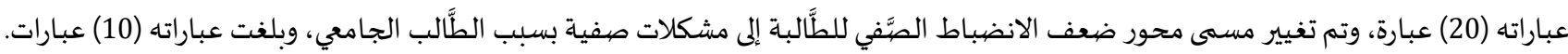

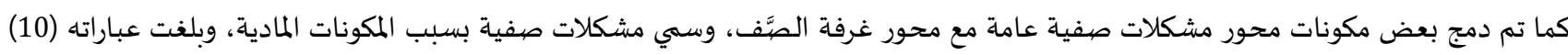

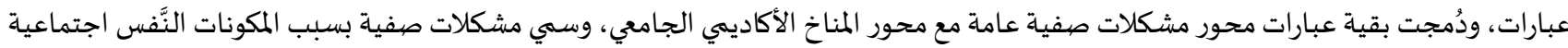

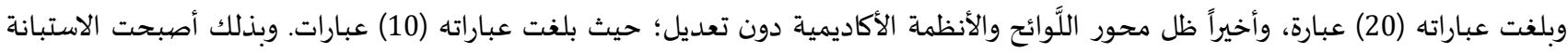

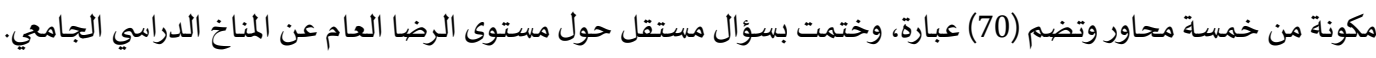

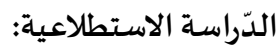

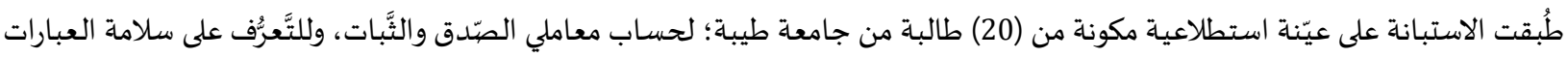

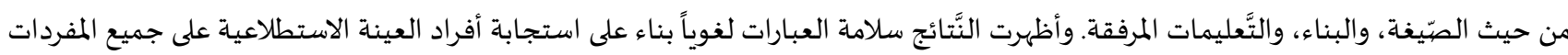
دون الحاجاة إلى الاستفسار. 
صهدق الاتساق الدَّاخلي لعبارات الاستبانة: تم حساب العلاقة بين العبارة والدَّرجة الكلية للمحور لمعرفة الاتساق الدَّاخلي بحساب معامل الارتباط بيرسون (Pearson)، وأظهرت نتائج

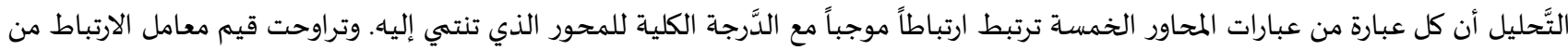

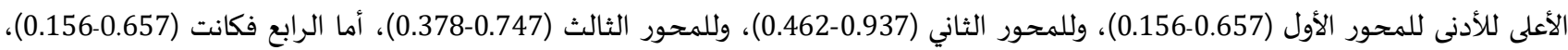

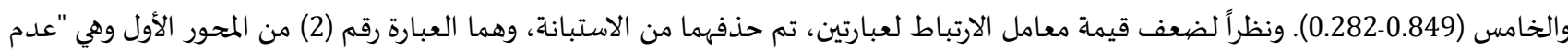

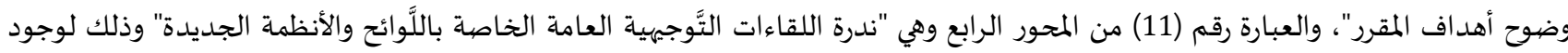

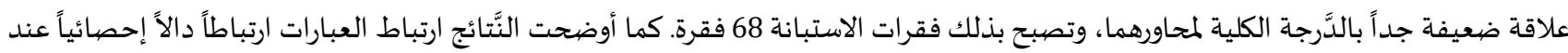

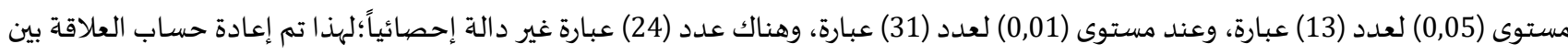

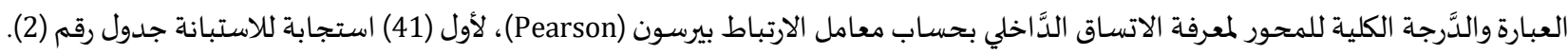

\begin{tabular}{|c|c|c|c|c|c|c|c|c|c|c|c|c|c|}
\hline \multicolumn{14}{|c|}{ جدول (2): حسـاب معامل الارتباط بين العبارات والدَّرجة الكلية للمحور الذي تنتهي إليه } \\
\hline معامل الارتباط & b & معامل & م & معامل & م & معامل & م & معامل & م & معامل & م & معامل & م \\
\hline & & الارتباط & & الارتباط & & الارتباط & & الارتباط & & الارتباط & & الارتباط & \\
\hline${ }^{* *} 0.811$ & 1 & & & ${ }^{* *} 0.580$ & 1 & $* 0.727$ & 1 & $* 0.316$ & 1 & ${ }^{* *} 0.614$ & 11 & ${ }^{* * 0} 0.511$ & 1 \\
\hline$* * 0.735$ & 2 & ${ }^{* *} 0.477$ & 12 & ${ }^{* *} 0.418$ & 2 & ${ }^{* * 0} 0.428$ & 2 & ${ }^{* *} 0.641$ & 2 & ${ }^{* *} 0.646$ & 12 & & \\
\hline${ }^{* *} 0.753$ & 3 & ${ }^{* *} 0.399$ & 13 & ${ }^{* *} 0.488$ & 3 & $* 0.799$ & 3 & ${ }^{* *} 0.601$ & 3 & ${ }^{* *} 0.541$ & 13 & ${ }^{* * 0} 0.488$ & 3 \\
\hline$* * 0.742$ & 4 & $* 0.371$ & 14 & $* 0.371$ & 4 & $* 0.584$ & 4 & ${ }^{* *} 0.724$ & 4 & ${ }^{* *} 0.671$ & 14 & ${ }^{* * 0} 0.719$ & 4 \\
\hline${ }^{* *} 0.650$ & 5 & ${ }^{* *} 0.503$ & 15 & ${ }^{* *} 0.444$ & 5 & ${ }^{* *} 0.619$ & 5 & ${ }^{* *} 0.505$ & 5 & ${ }^{* *} 0.733$ & 15 & $* 0.553$ & 5 \\
\hline$* * 0.792$ & 6 & ${ }^{* *} 0.625$ & 16 & ${ }^{* *} 0.738$ & 6 & ${ }^{* *} 0.422$ & 6 & ${ }^{* *} 0.569$ & 6 & ${ }^{* *} 0.718$ & 16 & ${ }^{* * 0} 0.589$ & 6 \\
\hline${ }^{* *} 0.733$ & 7 & $* 0.352$ & 17 & ${ }^{* *} 0.427$ & 7 & $* 0.716$ & 7 & ${ }^{* *} 0.604$ & 7 & ${ }^{* *} 0.665$ & 17 & $* 0.514$ & 7 \\
\hline${ }^{* *} 0.760$ & 8 & ${ }^{* *} 0.408$ & 18 & ${ }^{* *} 0.437$ & 8 & $* 0.735$ & 8 & ${ }^{* *} 0.527$ & 8 & ${ }^{* *} 0.731$ & 18 & $* 0.344$ & 8 \\
\hline${ }^{* *} 0.793$ & 9 & ${ }^{* *} 0.439$ & 19 & $* * 0.502$ & 9 & $* 0.567$ & 9 & ${ }^{* *} 0.446$ & 9 & ${ }^{* *} 0.767$ & 19 & $* 0.572$ & 9 \\
\hline$* * 0.761$ & 10 & ${ }^{* *} 0.477$ & 20 & ${ }^{* *} 0.446$ & 10 & $* 0.747$ & 10 & $* 0.649$ & 10 & ${ }^{* *} 0.798$ & 20 & $* 0.564$ & 10 \\
\hline
\end{tabular}

أظهرت نتائج التَّحليل في جدول (2) أن كل عبارة من عبارات المحاور الخمسة ترتبط ارتباطاً موجباً مع الدَّرجة الكلية للمحور الذي تنتمي إليه.

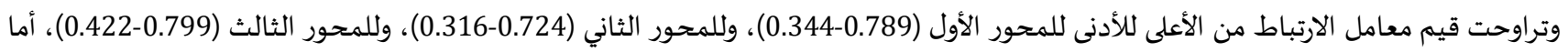

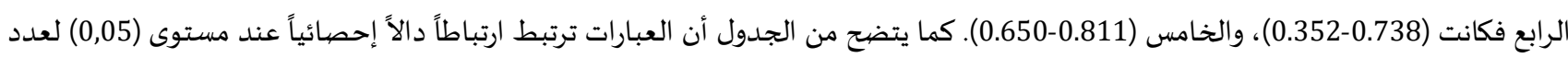

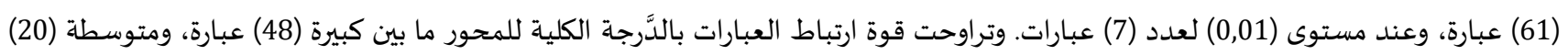

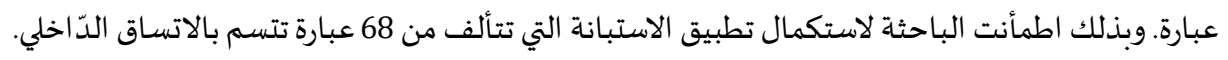

ثبات الاستبانة:

تم التَّأكد من ثبات درجات الاستبانة باستخد ام معادلة ألفا كرونباخ Cronbach’s Alpha للعبارات بعد حساب معامل الارتباط وهي 68 عبارة.

جدول (3): حساب معامل ألفا كرونباخ للتحقق من ثبات أداة الدراسة

\begin{tabular}{|c|c|c|c|c|c|c|c|}
\hline ثبات الاستبانة & الخامس & الر ابع & الثالث & الثاني & الأول & ن ن & المحور \\
\hline 68 & 10 & 19 & 10 & 10 & 19 & 20 & عدد العبارات \\
\hline 0.764 & 0.737 & 0.826 & 0.821 & 0.929 & 0.711 & & معامل الثَّبَات \\
\hline 68 & 10 & 19 & 10 & 10 & 19 & 41 & عدد العبارات \\
\hline 0.805 & 0.915 & 0.791 & 0.794 & 0.761 & 0.900 & & معامل الثَّبَات \\
\hline
\end{tabular}

وكما يظهر من الجدول رقم (3) أن قيم معاملات الثَّبات لمحاور الاستبانة ولإجمالي فقرات الاستبانة البالغ عددها (68) عبارة تُصنّف جميعاً من

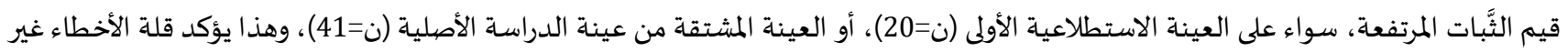

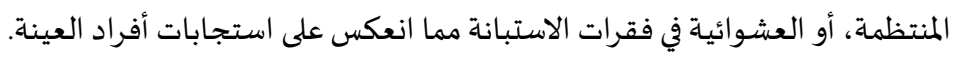
إجراءات الدراسـة: بعد التَّأكد من الخصائص السَّيكومترية لأداة الدراسة من صبدق وثبات، أمكن الخروج بالصيغة النهائية للاستبانة، ثم تم تحديد آلية توزيع

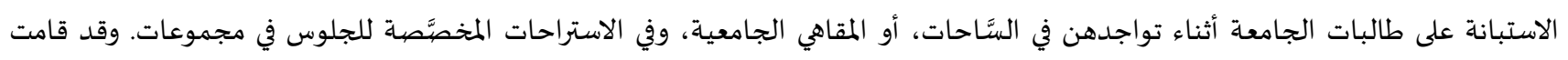

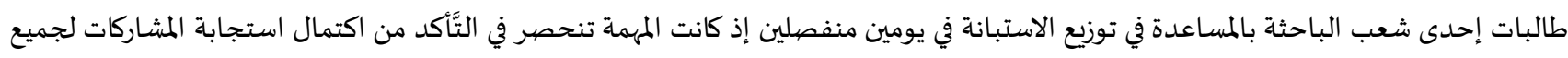

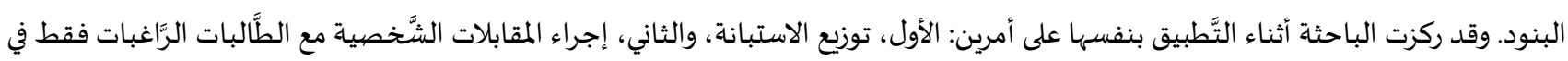


الاستجابة. وقد وجدت الباحثة تقبلاً شديداً وإيجابية من الطُّالبات، وكان البعض منهن يؤكدن أن العبارات تعكس واقعاً حقيقياً وملموساً. وقد تفاوت

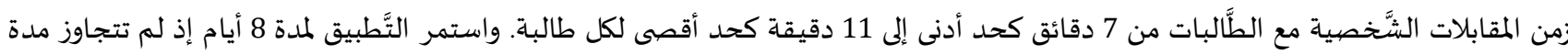

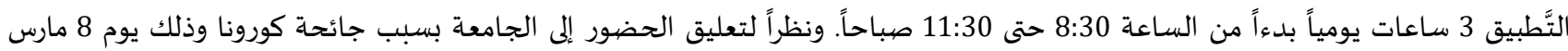

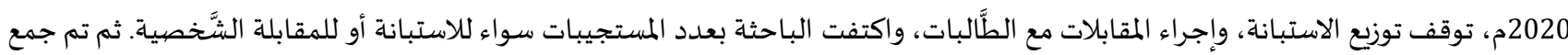

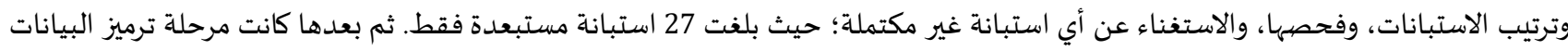

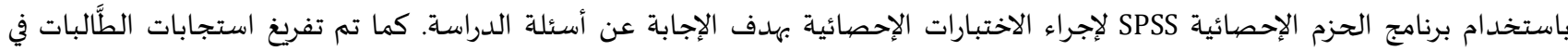

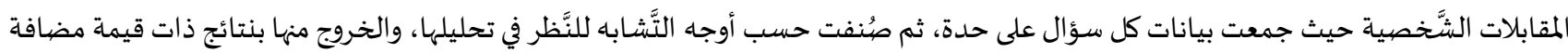

المعالجة الإحصيائية:

استخدمت الباحثة معامل ارتباط بيرسون لحساب الاتساق الدَّاخلي، ومعامل ألفا كرونباخ للتَّكد من ثبات درجات الاستبانة، والمتوسطات

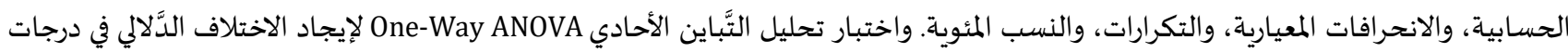

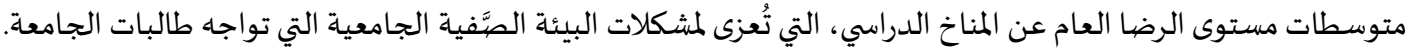

\section{نتائج الدراسة ومناقشتها:}

لتحقيق هدف الدراسـة، صيغت ثمانية أسئلة، وتم التَّحقق منها عن طريق المعالجات الإحصائية على النَّحو الآتي: إجابة سؤال الدراسة الأول:

للإجابة عن السُّؤال الأول حول أبرز المشكلات الصيَّفية التي مصدورها الأستاذ الجامعي، تم تحليل استطلاع آراء الطُّالبات، وكانت النَّتائج على

النَّحو الآتي:

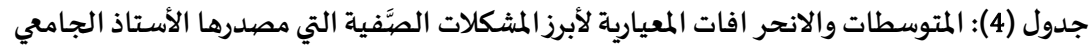

\begin{tabular}{|c|c|c|c|c|c|}
\hline 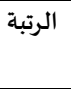 & الدَّرجة & المعياري & المتوسابي & عبارات المحور الأول: مشكلات صفية مصدرها الأستاذ الجامعي & م \\
\hline 1 & مرتفعة & 0.78 & 2.48 & زيادة وقت المحاضرة عن المخصيَّص في الجدول الرَّسمي. & .1 \\
\hline 2 & 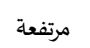 & 0.79 & 2.47 & تأجيل المحاضرة أو إلغاؤها دون إبلاغ الطًّالبات. & .2 \\
\hline 3 & 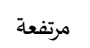 & 0.76 & 2.43 & قلة الإلمام بالمادة العلمية وطرق تدربسها. & .3 \\
\hline 4 & 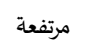 & 0.78 & 2.42 & غموض أنشطة وواجبات المقرر. & .4 \\
\hline 5 & 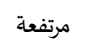 & 0.77 & 2.41 & لا توجد أنشطة صفية محفزة. & .5 \\
\hline 6 & 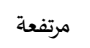 & 0.76 & 2.40 & عدم الالتزام بمواعيد بدء المحاضرات. & .6 \\
\hline 7 & 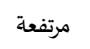 & 0.82 & 2.39 & عدم تحديد مواعيد الاختبارات الدَّورية في خطة المقرر. & .7 \\
\hline 8 & متوسطة & 0.80 & 2.33 & شيوع العشوائية في عرض محتوى المقرر. & .8 \\
\hline 8 & متوسطة & 0.79 & 2.33 & عدم الالتزام بمواعيد الساعات المكتبية. & .9 \\
\hline 10 & متوسطة & 0.84 & 2.31 & عدم تزويد الطًالبات بخطة المقرر. & .10 \\
\hline 11 & متوسطة & 0.86 & 2.29 & عدم الالتزام بمواعيد الاختبارات الدَّورية المحددة في خطة المقرر. & .11 \\
\hline 12 & متوسطة & 0.80 & 2.27 & 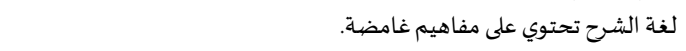 & .12 \\
\hline 13 & متوسطة & 0.84 & 2.26 & عدم الالتزام بموضوعات المقرر المحددة سلفاً. & .13 \\
\hline 14 & متوسطة & 0.82 & 2.26 & ضعف القدرة على ضبط الصيَّف وإدارته بفاعلية. & .14 \\
\hline 15 & متوسطة & 0.82 & 2.25 & 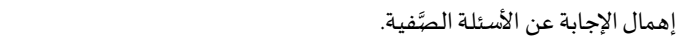 & .15 \\
\hline 15 & متوسطة & 0.81 & 2.25 & عدم الالتزام بالمطلوب من الواجبات والأنشطة المحددة. & .16 \\
\hline 17 & متوسطة & 0.85 & 2.24 & 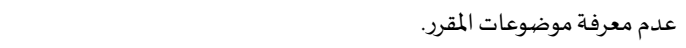 & .17 \\
\hline 18 & متوسطة & 0.84 & 2.17 & عدم الالتزام بمواعيد تسليم الواجبات والأنشطة الصَّفية. & .18 \\
\hline 19 & متوسطة & 0.86 & 2.13 & عدم تخصيص مواعيد للسنّاعات المكتبية. & .19 \\
\hline
\end{tabular}

توضيح النَّائج في جدول (4) أن عينة الدراسة قدرت سبع مشكلات موجودة بصورة مرتفعة في البيئة الصَّفية الجامعية، ومرتبطة بالأستاذ

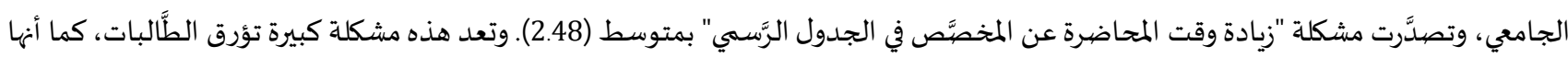

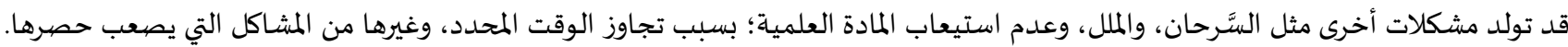

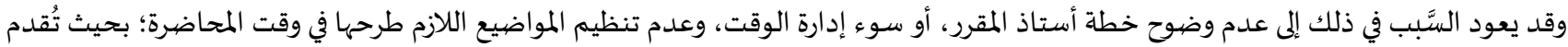

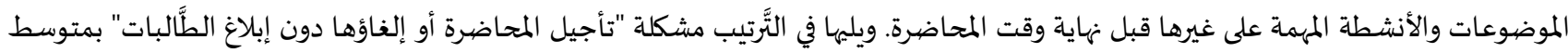

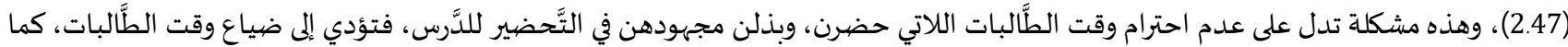


أنها يعد إخلالًا بأحد حقوق الطَّالبة الجامعية الموضحة في اللَّوائح الجامعية، كما أن موافقة العينة على توافرها بصيورة مرتفعة يدل على انتشارها بشكل كبير في بيئة الصَّف الجامعية.

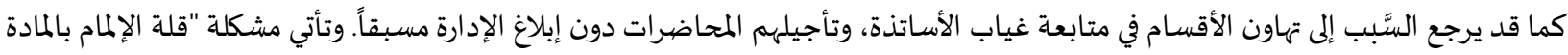

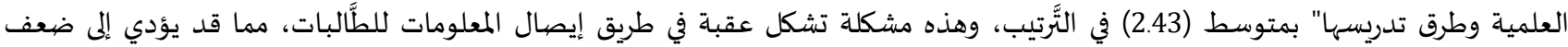

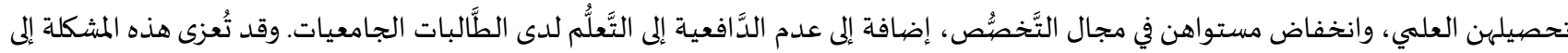
ضيعف الإعداد المهني لبعض الأساتذة الجامعيين خاصية في التَّخصُّصات العلمية والصحية، مع عدم حرص بعضهيهم على التَّطوير المهني من خلال

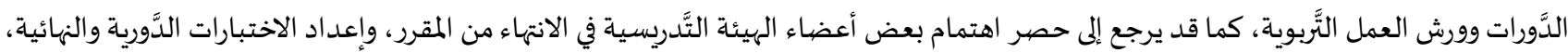

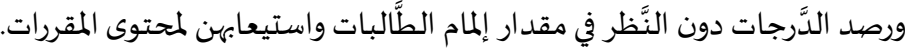

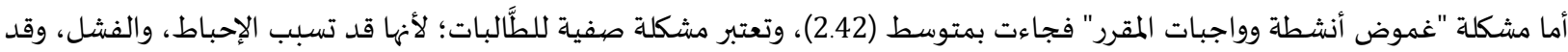
تؤثر على إبداع الطَّالبات في تأدية الواجبات بابتكارية وفي نطاق المطلوب أداؤه. وقد يرجع السَّبب في هذا الغموض إندات إلى عدم التزام أستاذ المقرر بمتطللَّبات

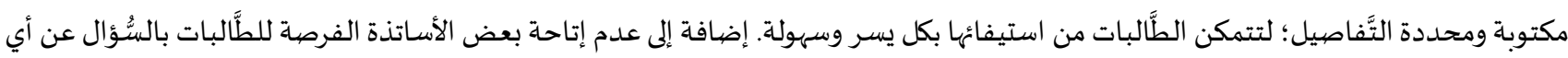

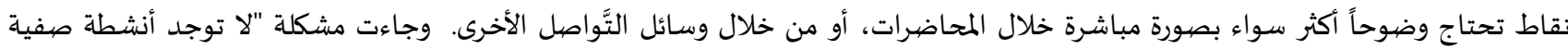

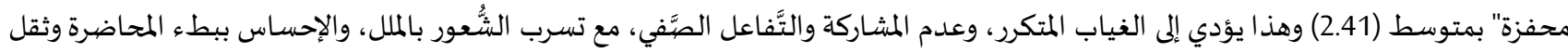

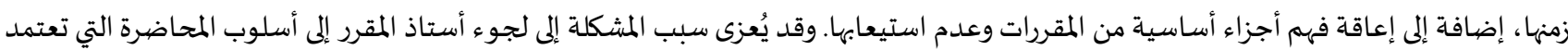

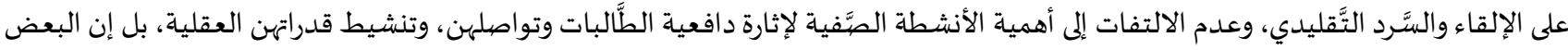

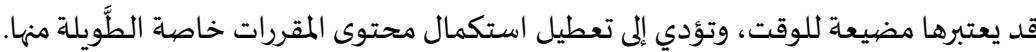

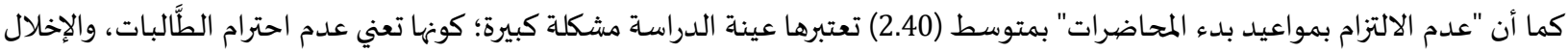

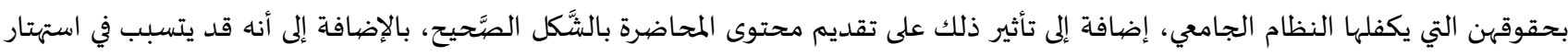

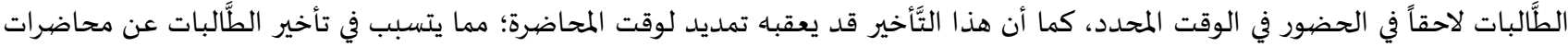
أخرى. وقد يرجع ذلك إلى عدم مهنية الأستاذ الجامعي، وغياب المراقبة الإدارية من الأقسام، إضافة إلى عدم شعورهم الكافي بالمسؤولية تجاه عملهيهم الأكاديمي.

وأخيراً مشكلة "عدم تحديد مواعيد الاختبارات الدَّورية في خطة المقرر" جاءت بمتوسط (2.39)، وهي تشير إلى قيمة متوسط مرتفعة، وهذا حتماً

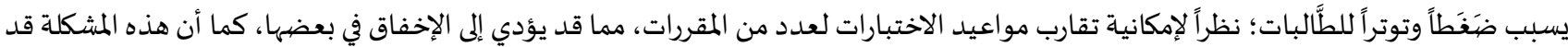

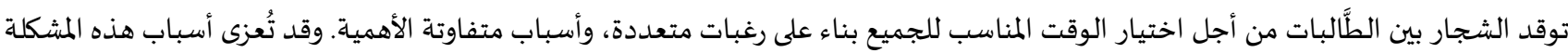

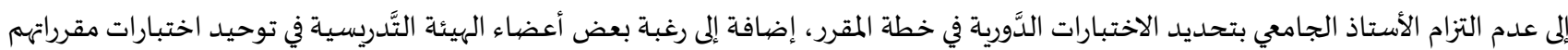

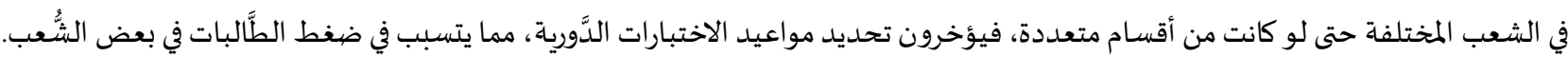

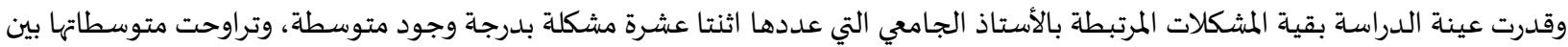

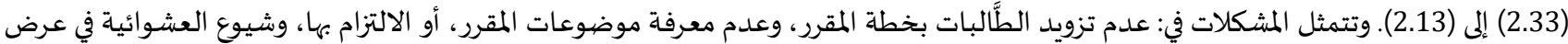

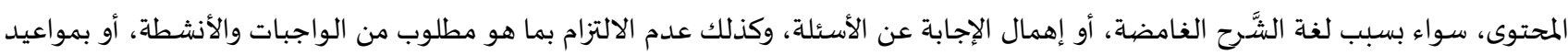

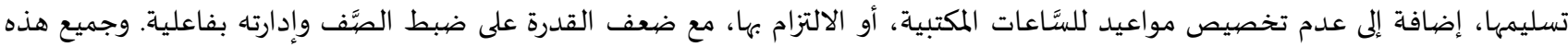

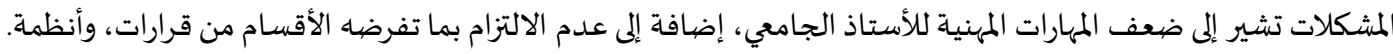
واتفقت نتائج هذا المحور مع نتائج دراسة العرجان والعضايلة (2010)، ودراسة الجميلي (2012)، ودراسة صئية صيفي وآخرون (Saifi et al., 2018) ودراسة الضَّالعي والمخلافي (2019)، ودراسة الضَّو (2019) التي أكدت أن من بين المشكلات التي يعاني مها طلبة الجامعة ومصدروها الأستاذ الجامعي: استخدام طرق تدريسية تقليدية، وضعف استخدام التَّقنيات في التَّدريس، وعدم الالتزام بالسـاعات المكتبية، وإهمال إجابة أسئلة الطُّلَّة. إجابة سؤال الدراسة الثاني: لمعرفة أبرز المشكلات الصَّفية التي مصيدرها الطَّالب، تم تحليل استطلاع آراء طالبات جامعة طيبة، وكانت النَّتائج على النَّحو الآتي:

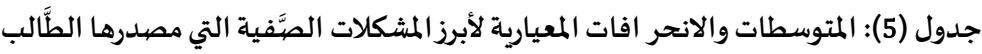

\begin{tabular}{|c|c|c|c|c|c|}
\hline الرتبة & الدَّرجة & المعياري & المسابي & عبارات المحتور الثاني: مشكلات صفية مصدرها الطًالب الجامعي & م \\
\hline 1 & متوسطة & 0.85 & 2.25 & الأحاديث الجانبية في غير موضوع الدَّرس. & .1 \\
\hline 2 & متوسطة & 0.91 & 2.24 & السُّخرية من إجابات الزَّميلات في الفصل أو على مجموعات الواتساب. & .2 \\
\hline 2 & متوسطة & 0.89 & 2.24 & عدم احترام وتقبل آراء الزَّميلات في الفصل أو على مجموعات الواتساب. & .3 \\
\hline 2 & متوسطة & 0.88 & 2.24 & عدم القيام بالمهام المطلوبة ضهمن فريق العمل الجماعي. & .4 \\
\hline
\end{tabular}




\begin{tabular}{|c|c|c|c|c|c|}
\hline 5 & متوسطة & 0.87 & 2.21 & النقاش الصيَّفي غير المنضبط في الفصل أو على مجموعات الواتساب. & .5 \\
\hline 6 & متوسطة & 0.86 & 2.20 & استخدام الأجهزة الذكية لأمور شخصية. & 6 \\
\hline 7 & متوسطة & 0.89 & 2.18 & الرد بصورة غير لائقة على أساتذة المقررات. & .7 \\
\hline 8 & متوسطة & 0.91 & 2.12 & عدم احترام خصوصية الزميلات أو ممتلكاتهن. & .8 \\
\hline 9 & متوسطة & 0.85 & 2.08 & العزوف عن التَّفاعل في الأنشطة الصَّفية وعدم الاشتراك فهيا. & .9 \\
\hline 9 & متوسطة & 0.87 & 2.08 & سوء اختيار أوقات التََّاصل الفردي الإلكتروني مع أساتذة المقررات. & .10 \\
\hline
\end{tabular}

توضح النَّائج في جدول (5) أن عينة الدراسة قدرت جميع المشكلات المرتبطة بالطَّالبة الجامعية إلى درجة متوسطة، وتراوحت متوسطاتها بين

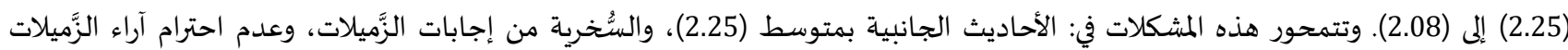

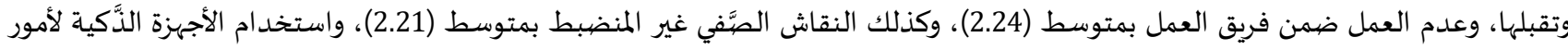
شخصية بمتوسط (2.21)، والرَّد بصورة غير لائقة على أساتذة المقررات بمتوسط (2.18)، بالإضافة إلى عدم احترام خصوصية الزميلة أو ممتلكاتها

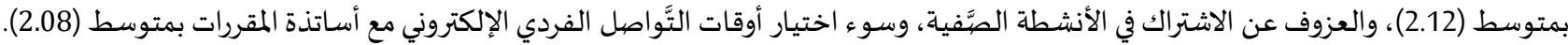

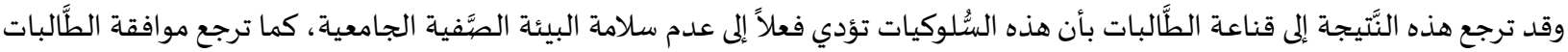

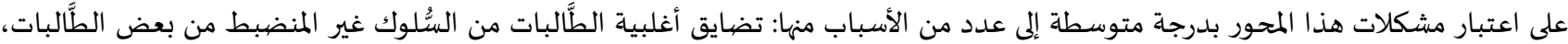

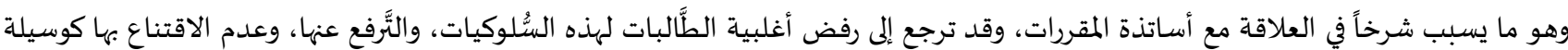

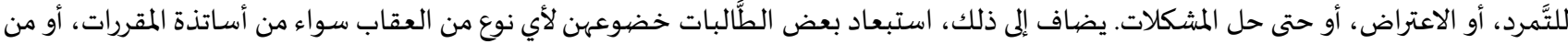

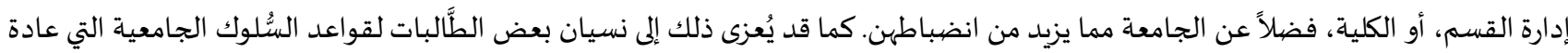

تستعرضها الكليات للمستجدات عند تسجيلهن في الجامعة.

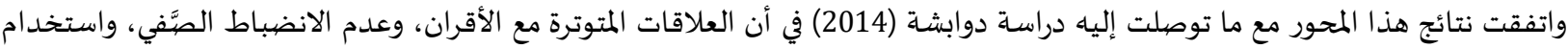

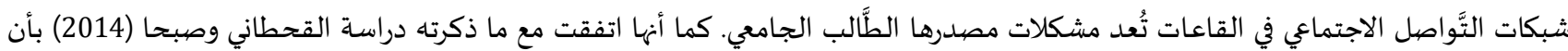

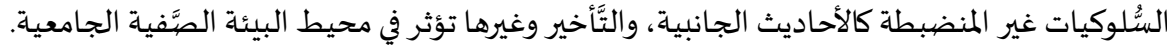

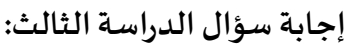
لمعرفة أبرز المشكلات الصَّفية التي مصدرها المككونات المادية، تم تحليل استطلاع آراء طالبات جامعة طيبة، وكانت النَّتائج على النَّحو الآتي:

\begin{tabular}{|c|c|c|c|c|c|}
\hline 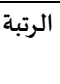 & الدَّرجة & المعياري & المتوسطي & عبارات المحور الثالث: مشكلات صفية مصدرها المكونات المادية & م \\
\hline 1 & مرتفعة & 0.76 & 2.50 & لا تتوفر أجهزة حاسب آلي داخل القاعات لتيسير عرض الدَّرس. & .1 \\
\hline 2 & 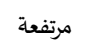 & 0.76 & 2.48 & تفتقد القاعة إلى إمكانية العمل في مجموعات. & .2 \\
\hline 3 & 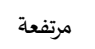 & 0.76 & 2.43 & 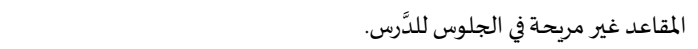 & .3 \\
\hline 4 & 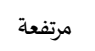 & 0.78 & 2.34 & تتسم أجهزة العرض بعدم مناسبة حجم الشًّاشة المعروضة. & .4 \\
\hline 4 & 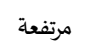 & 0.78 & 2.34 & يصعب فتح أجهزة العرض وإغلاقها. & .5 \\
\hline 6 & 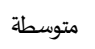 & 0.78 & 2.31 & يتسم جو القاعة بالبرودة الشَّديدة. ل & .6 \\
\hline 7 & متوسطة & 0.83 & 2.20 & تتسم أجهزة العرض بعدم دقة وضوح اللَّون والخط. & .7 \\
\hline 8 & متوسطة & 0.86 & 2.17 & ضعف الإضاءة في غرفة الصَّف. & .8 \\
\hline 9 & متوسطة & 0.88 & 2.15 & تخلو غرفة الصَّفَ من نوافذ قابلة لإدخال التَّهوية وضوء الشَّمس. & .9 \\
\hline 10 & متوسطة & 0.84 & 2.07 & يتسم جو القاعة بالحر الشديد. & .10 \\
\hline
\end{tabular}

وبالنَّظر إلى جدول (6) يتضح أن عينة الدراسة قدرت خمس مشكلات بأنها موجودة بصورة مرتفعة في البيئة الصَّفية الجامعية ومرتبطة بالمكونات المادية للصيّف. وتصدَّرت مشكلة "عدم توفر أجهزة حاسب آلي داخل القاعات لتيسير عرض الدَّرس" بمتوسط (2.50)، واعتبرتها عينة الدراسة مشكلة

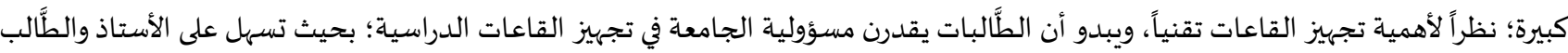

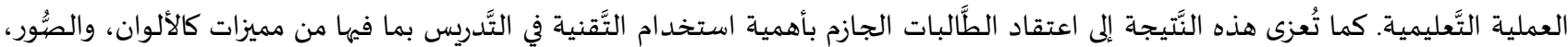

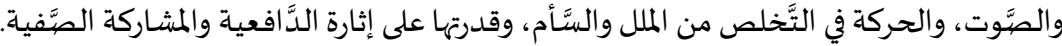

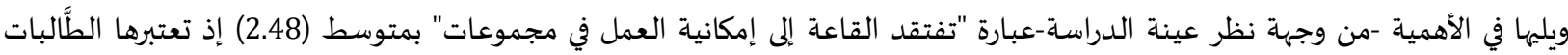

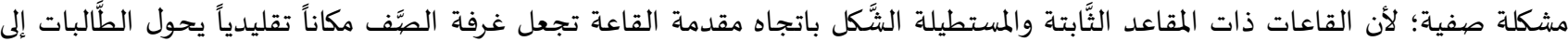

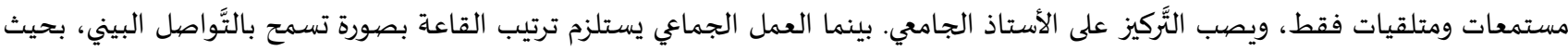

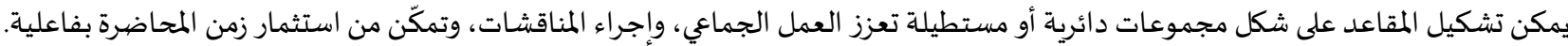




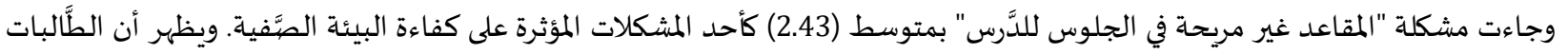

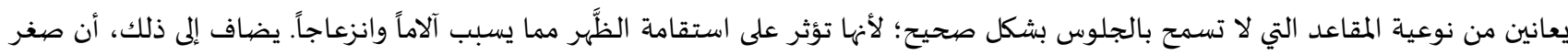

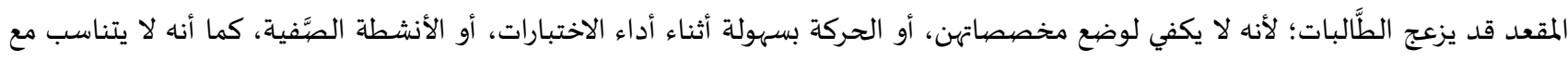

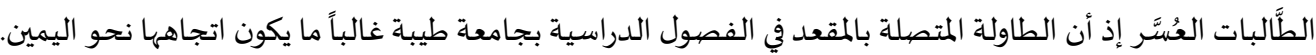

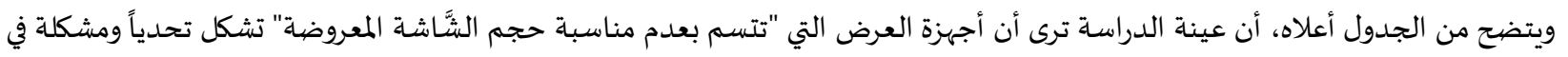

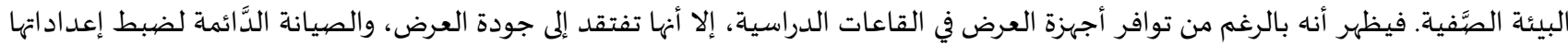

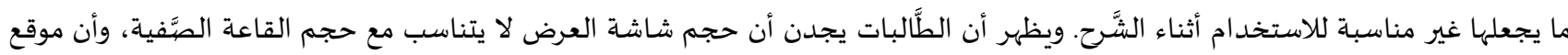

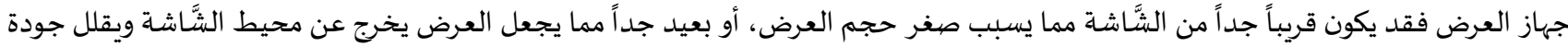

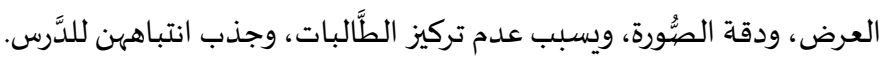

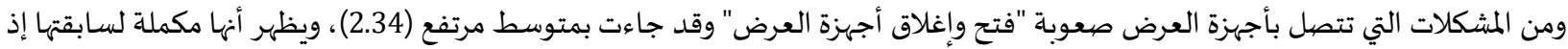

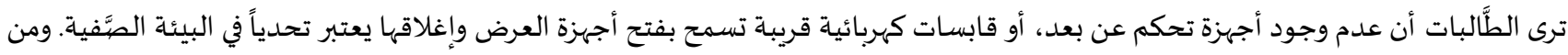

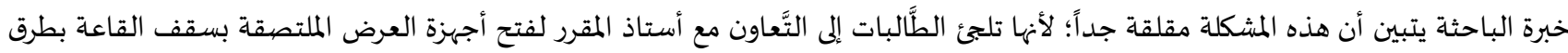

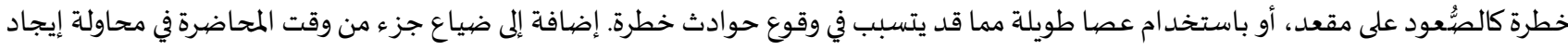
طريقة لفتح أجهزة العرض.

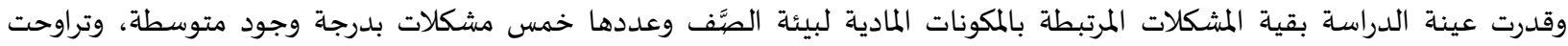

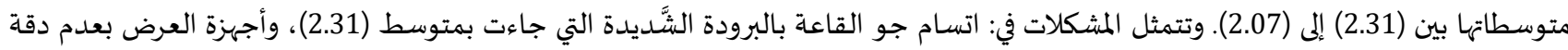

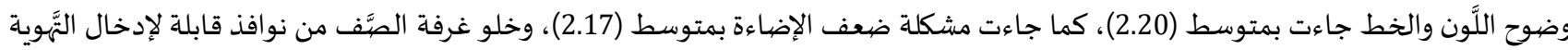

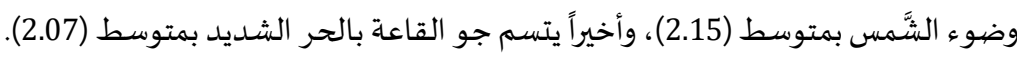

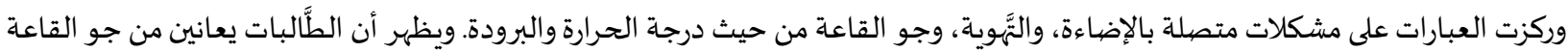

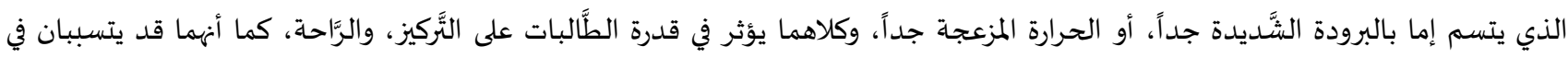

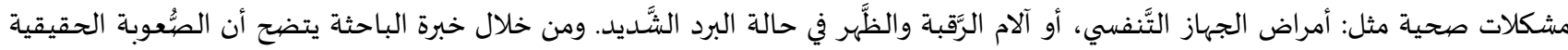

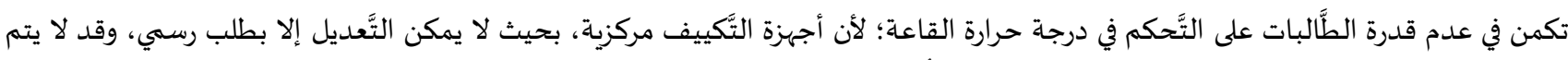

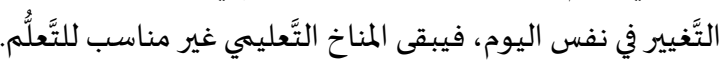

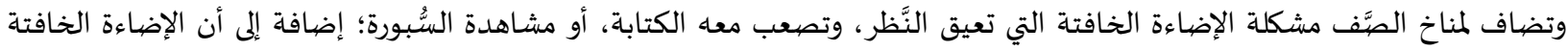

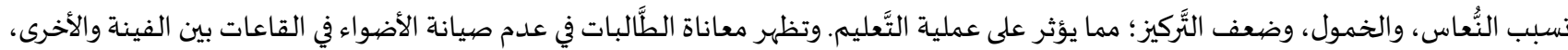

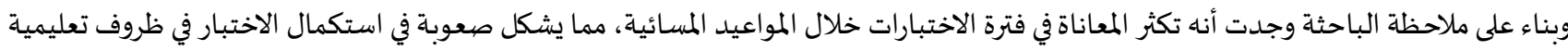

كما أن الطَّلبات يعانين من خلو بعض غرف الصَّف من النَّوافذ القابلة لإدخال ضوء الشَّمس والتَّهوية الصحية رغم أنه مطلب صحي جداً،

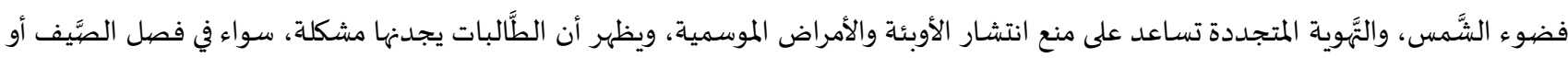

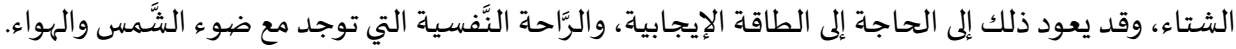

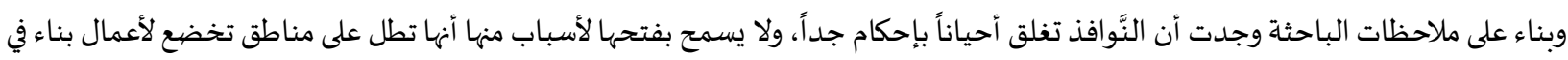

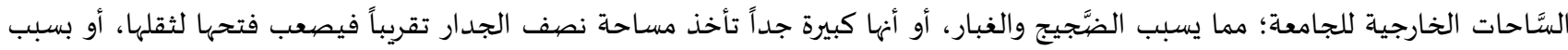
إطلالتها على منافذ داخلية في مباني الكليات فلا منفعة من فتحها المبا أصلاً.

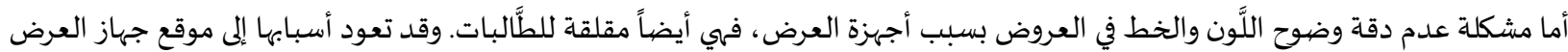

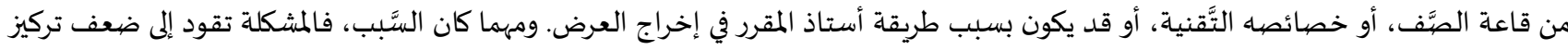

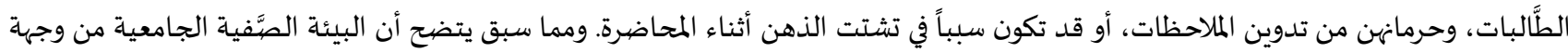

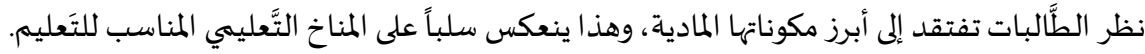

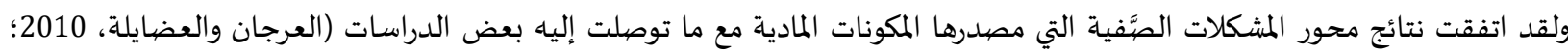

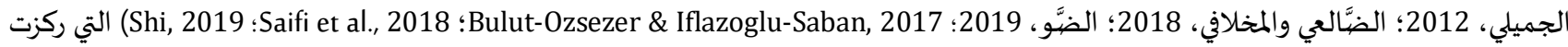

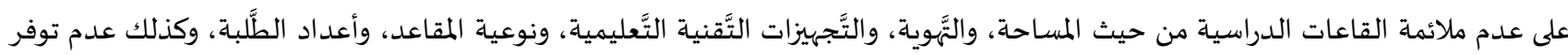
المعامل والمختبرات. 
إجابة سؤال الدراسة الر ابع: إبة

للإجابة عن سؤال الدراسة الرابع حول أبرز المشككلات الصيَّفية التي مصدرها المككونات النَّفس اجتماعية، تم تحليل استطلاع آراء طالبات جامعة

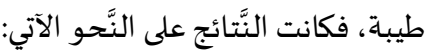

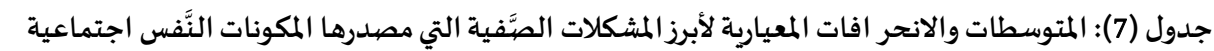

\begin{tabular}{|c|c|c|c|c|c|}
\hline الرتبة & الدَّرجة & المعياري الانحراف & الحستابي & عبارات المحور الر ابع: مشكلات صفية مصدرهها المكونات النَّفس اجتماعية & r \\
\hline 1 & مرتفعة & 0.69 & 2.60 & صعوبة حضور الفعاليات أو الاشتراك فها بسبب الجداول المزدحمة. & .1 \\
\hline 2 & 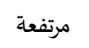 & 0.73 & 2.54 & ندرة تكريم المتفوقات والماهرات في الصيَف، أو القسم، والكلية، والجامعة. & .2 \\
\hline 3 & 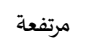 & 0.75 & 2.49 & 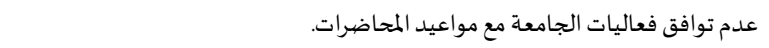 & .3 \\
\hline 4 & 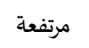 & 0.74 & 2.42 & قلة المسابقات العلمية والثَّقافية المحفزة. & .4 \\
\hline 5 & 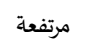 & 0.79 & 2.36 & ندرة الفعاليات على نطاق القسم المتخصص أو الكلية. & .5 \\
\hline 6 & 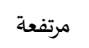 & 0.82 & 2.34 & تفضيل ذوي التَّحصيل المرتفع على غيرهن من الطَالبات. & 6 \\
\hline 6 & 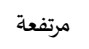 & 0.82 & 2.34 & تسرُب الإحباط والتَّتوتر إلى نفوس الطُالبات. & .7 \\
\hline 8 & متوسطة & 0.81 & 2.32 & ضعف الإعلان عن الأنشطة والفعاليات على نطاق الجامعة. & .8 \\
\hline 8 & متوسطة & 0.81 & 2.32 & عدم تشجيع الطًالبات على المشاركات العلمية المحلية والإقليمية. & .9 \\
\hline 10 & متوسطة & 0.77 & 2.30 & عدم التزام الكليات والأقسام بساعات النَّشاط الصَّفي الأسبوعية. & .10 \\
\hline 10 & متوسطة & 0.80 & 2.30 & ضعف تقدير الموهبة والإبداع لدى الطُّالبات أثناء الأنشطة والفعاليات. & .11 \\
\hline 12 & متوسطة & 0.83 & 2.29 & الاستهتار بقدرات الطَّلبات وإبداعاتهن. & .12 \\
\hline 13 & متوسطة & 0.83 & 2.27 & عدم العدالة بين الطَّالبات في الهرَّف. & .13 \\
\hline 14 & متوسطة & 0.85 & 2.26 & حسم الدَّرجات مباشرة عند أي مشكلة عابرة. & .14 \\
\hline 15 & متوسطة & 0.85 & 2.25 & الصُُراخ والتَّأنيب للطًُالَبات بشكل متكرر. & .15 \\
\hline 16 & متوسطة & 0.82 & 2.22 & عدم الاستماع والإصغاء لآراء الطًالبات. & .16 \\
\hline 17 & متوسطة & 0.85 & 2.21 & التَّسلط الظاهر في إدارة الصيَّف. & .17 \\
\hline 18 & متوسطة & 0.80 & 2.15 & الافتقاد إلى روح الدُّعابة وحس الفكاهة. & .18 \\
\hline 19 & متوسطة & 0.84 & 2.13 & عدم فسح المجال للنقاش داخل الصَّف. & .19 \\
\hline
\end{tabular}

وبالنَّظر إلى جدول (7) يتضح أن عينة الدراسة قدرت وجود سبعة مشكلات بصورة مرتفعة في البيئة الصَّفية الجامعية مرتبطة بالمكونات النَّفس

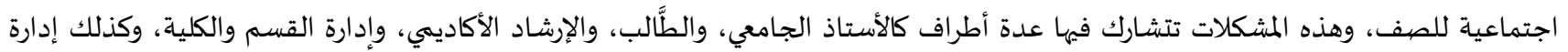

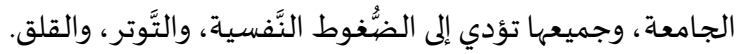

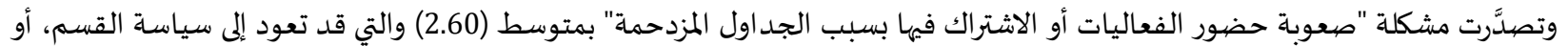

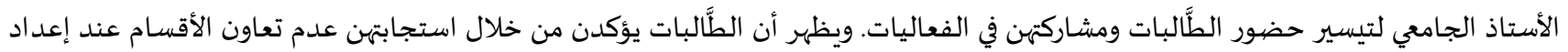

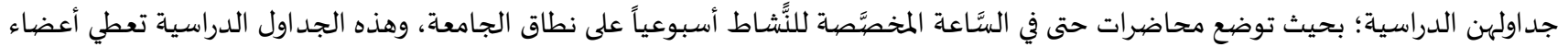

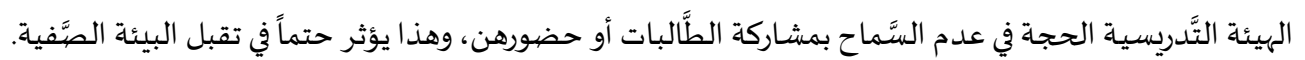

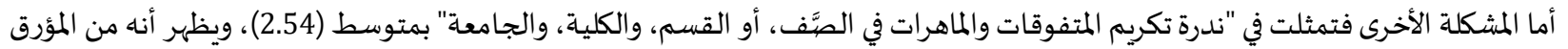

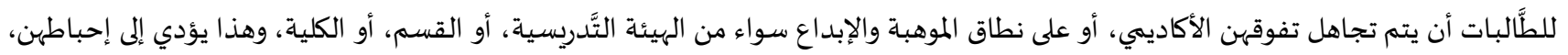

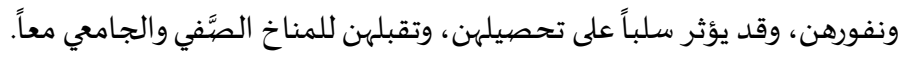

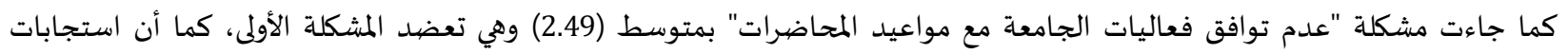

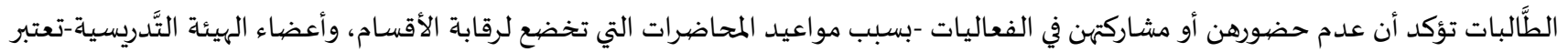

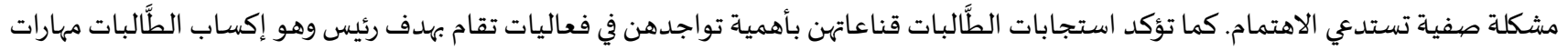

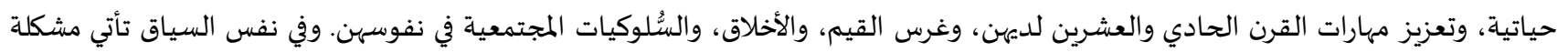

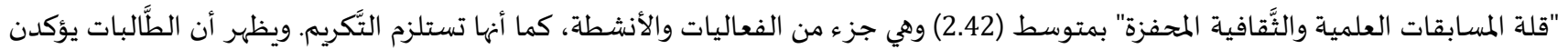

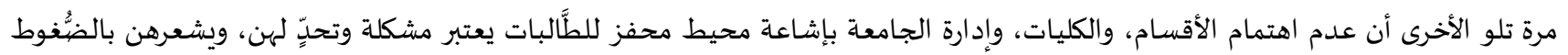

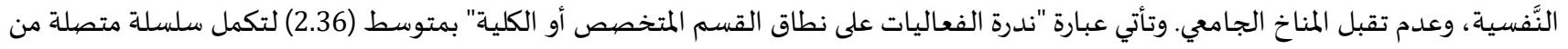

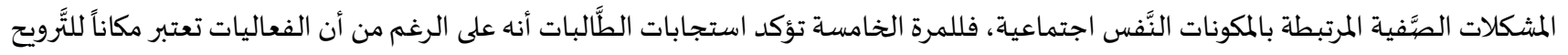

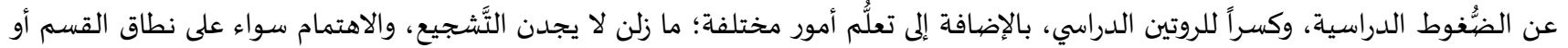
الكلية. 


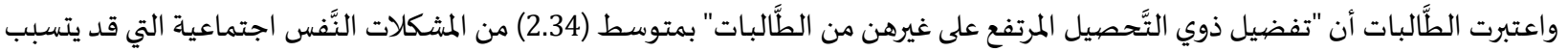

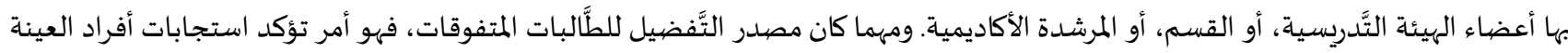

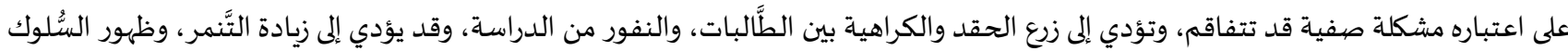

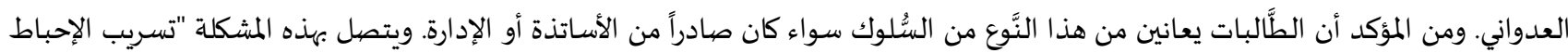

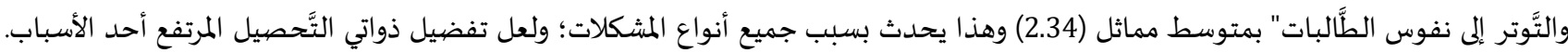

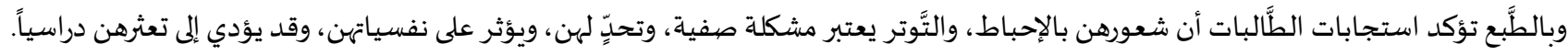

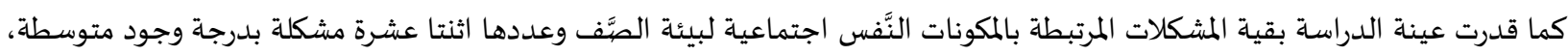

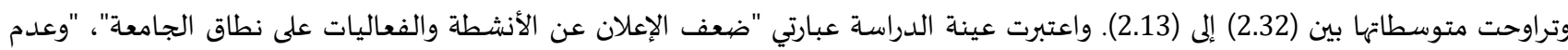

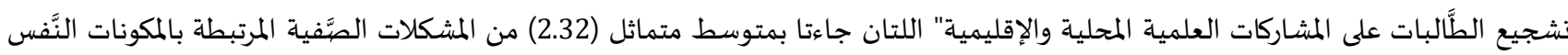

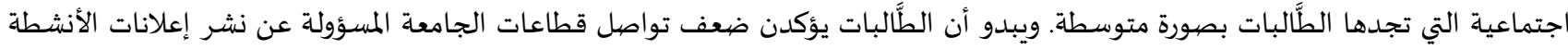

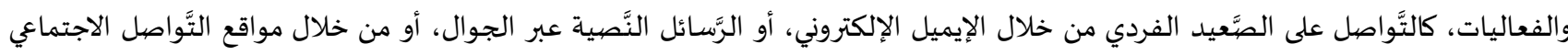

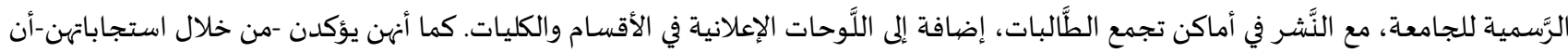

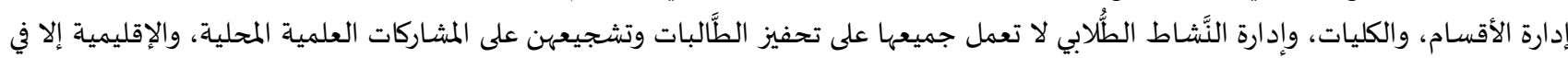

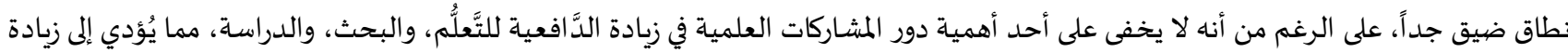

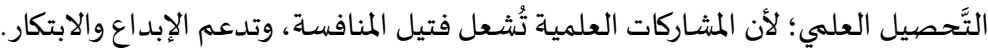

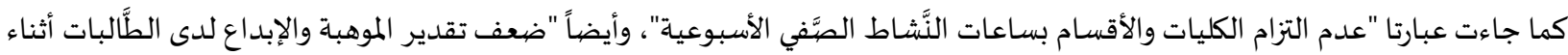

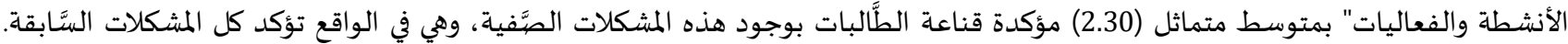

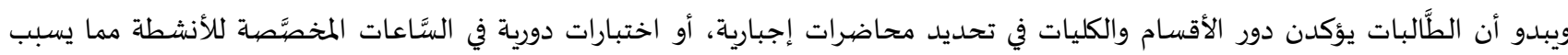

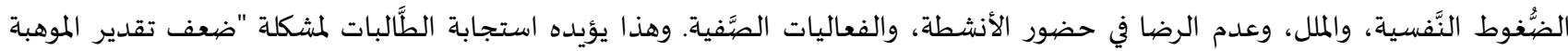

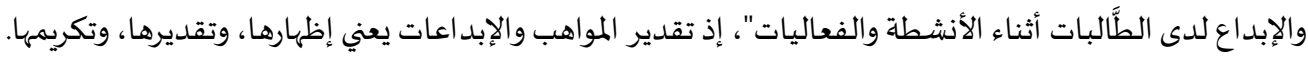

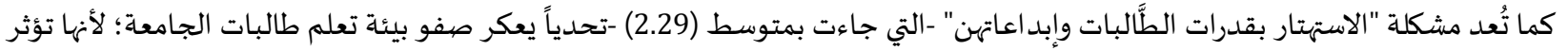

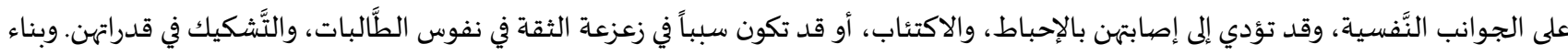

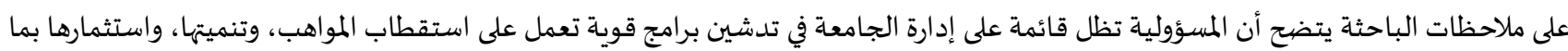

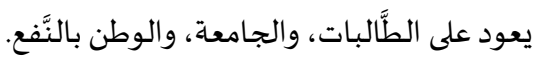

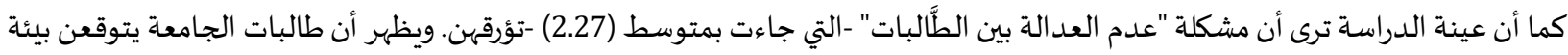

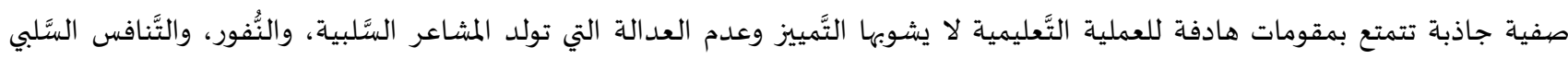

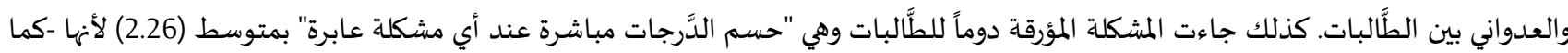

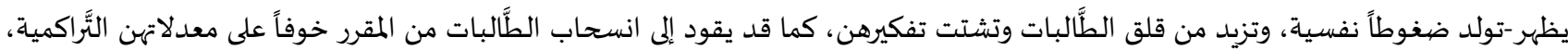

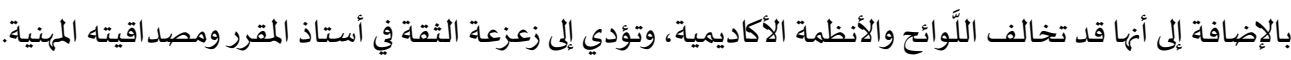

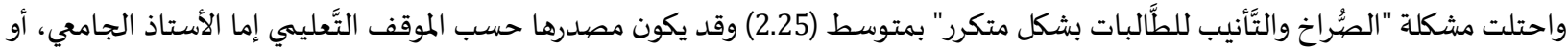

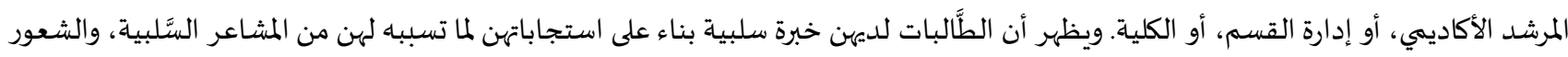

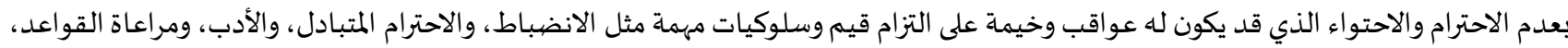

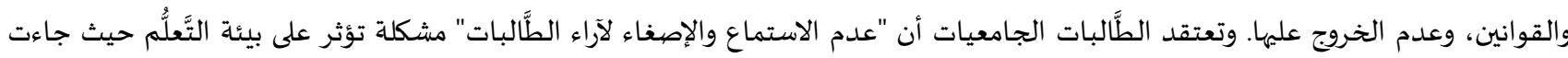

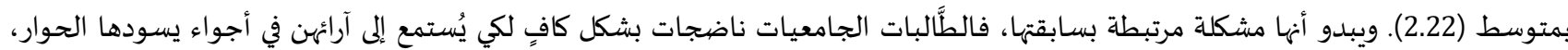

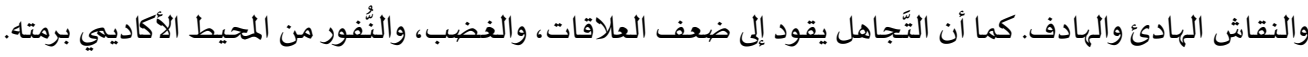

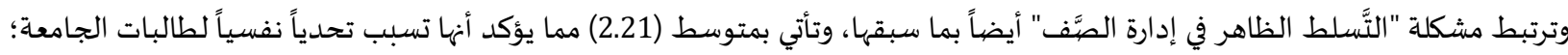

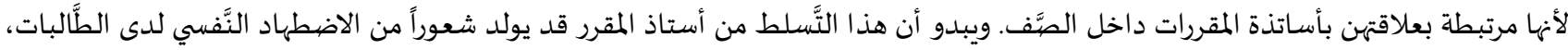

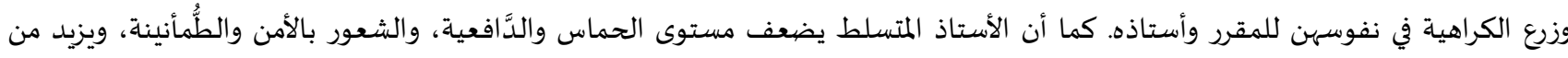

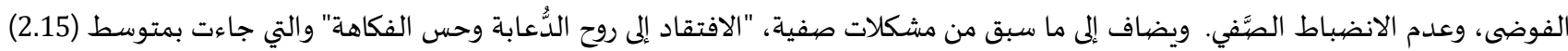

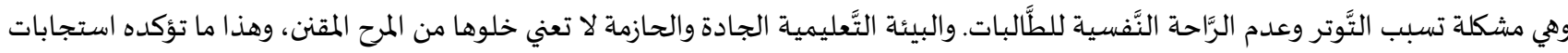

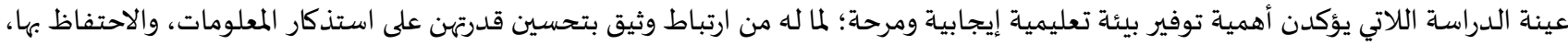

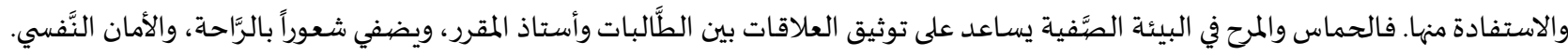




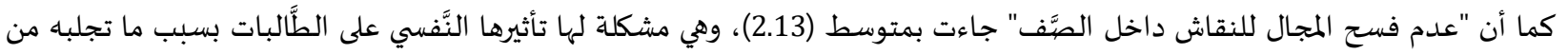

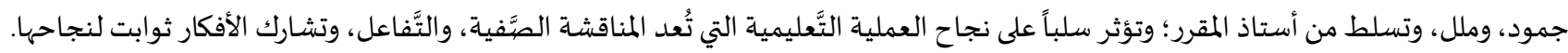

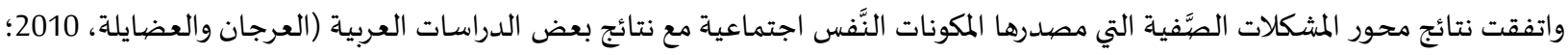

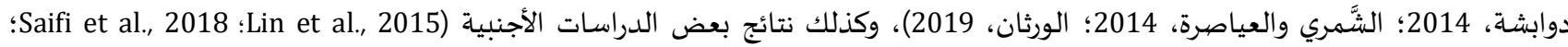
(Aladwan et al., 2019

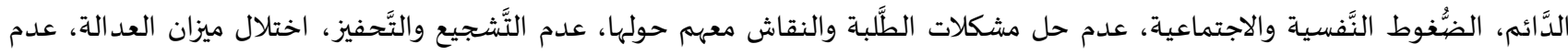

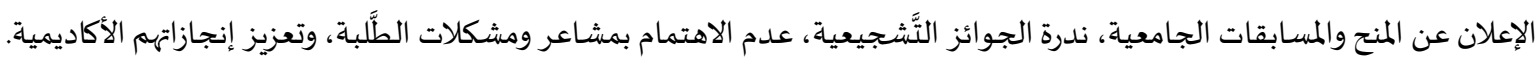

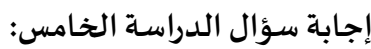
لمعرفة أبرز المشكلات الصَّفية التي مصدروها اللَّوائح والأنظمة الأكاديمية، تم تحليل استطلاع آراء الطُّالبات فكانت النَّائج على النَّحو الآتي:

\begin{tabular}{|c|c|c|c|c|c|}
\hline 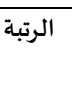 & الدَّرجة & المعياري & المستابي & عبارات المحتور الخامس: مشكلات صفية مصدرها اللَّو ائح والأنظمة الأكاديمية & s \\
\hline 1 & مرتفعة & 0.72 & 2.58 & عدم إتاحة مقررات اختيارية كافية ومنوعة. & .1 \\
\hline 2 & 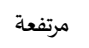 & 0.73 & 2.56 & عدم إمكانية اختيار المرشدة الأكاديمية. & .2 \\
\hline 3 & مرتفعة & 0.74 & 2.52 & عدم إمكانية اختيار المقررات التَّخصُُصية. & 3 \\
\hline 4 & 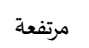 & 0.75 & 2.50 & ضيعف التَّواصل الإلكتروني بين الإدارة والطَّالبات. & .4 \\
\hline 5 & 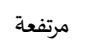 & 0.77 & 2.48 & عدم حرص القسم على ترتيب مواعيد المحاضرات بشكل مناسب. & .5 \\
\hline 6 & 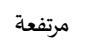 & 0.78 & 2.47 & 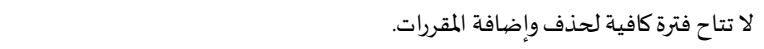 & .6 \\
\hline 7 & 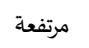 & 0.80 & 2.46 & لا تقام لقاءات فصلية لتوجيه الطًالبات فيما يخص الأنظمة الجديدة. & .7 \\
\hline 8 & 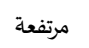 & 0.83 & 2.36 & لا يوجد دليل مفصل لمقررات القسم والكلية والجامعة. & .8 \\
\hline 9 & متوسطة & 0.83 & 2.31 & لا يوجد أدلة أو منشورات خاصة باللَّائح والأنظمة الاكاديمية. & 9 \\
\hline 10 & متوسطة & 0.84 & 2.27 & عدم تواجد المرشدة الأكاديمية في ساعتها المخصصَّصة للإرشاد. & .10 \\
\hline
\end{tabular}

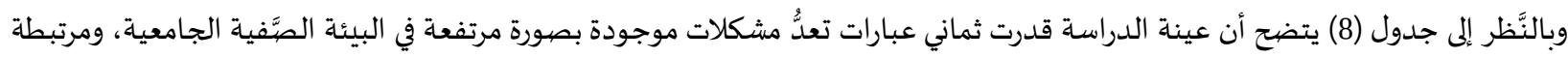

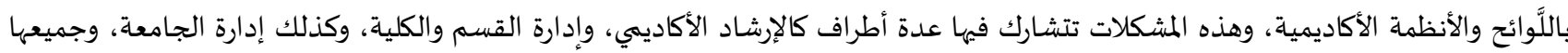
تؤدي إلى مشكلات في المناخ الجامعي. وقد جاءت مشكلة "عدم إتاحة مقررات اختيارية كافية ومنوعة" في المرتبة الأولى بمتوسط (2.58) وهي تؤكد معاناة الطُّألبات في عدم ملاءماتة

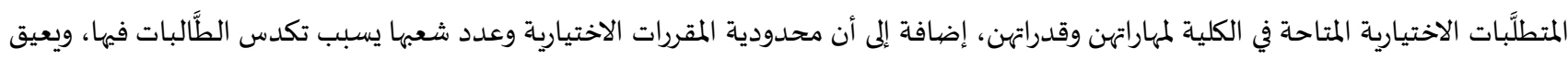

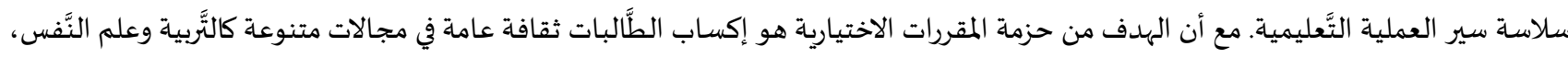

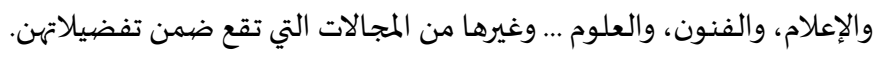

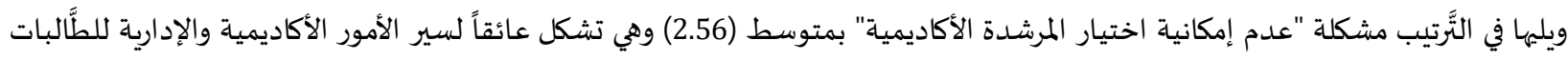

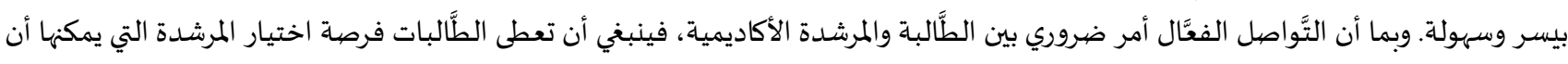

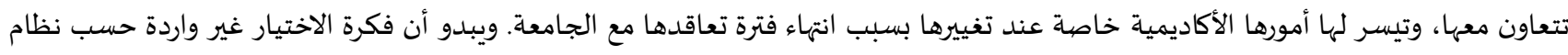

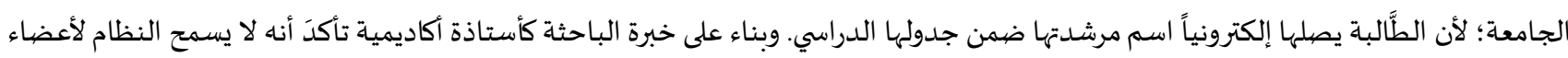

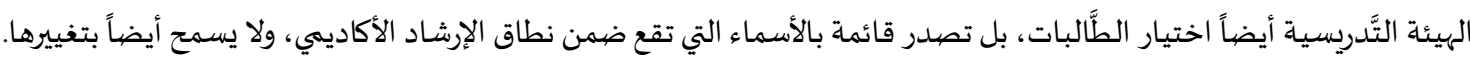

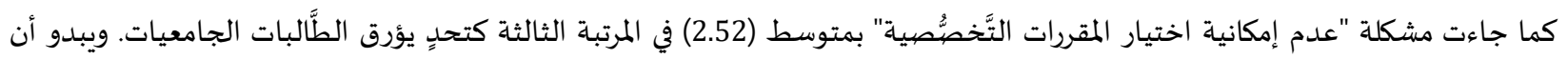

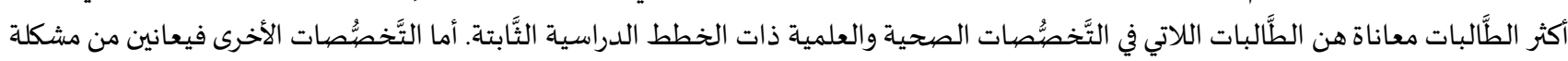

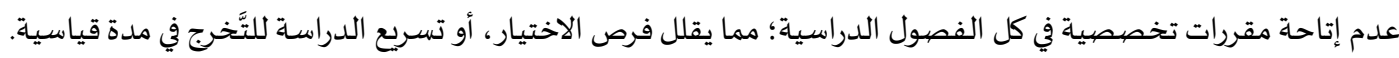

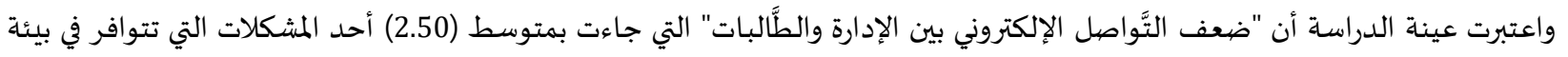

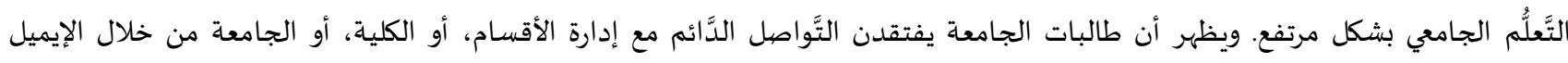

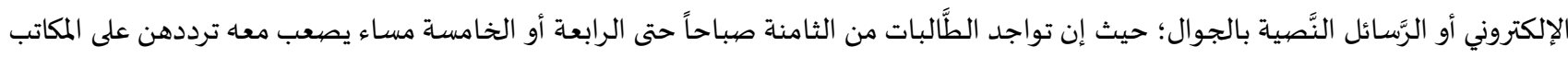

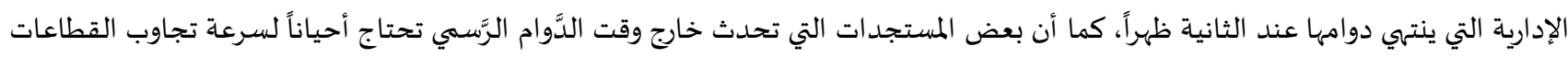

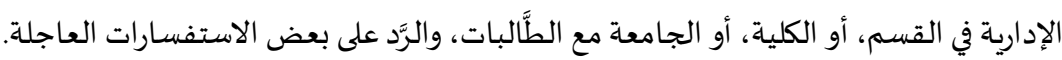

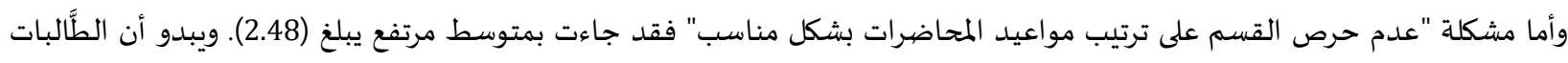

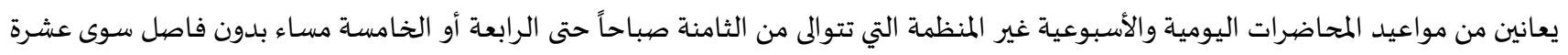


دقائق من محاضرة لأخرى، أو أهها تنظم بفاصل يصل إلى ثلاث أو أربع ساعات بين محاضرة وأخرى. ومن المؤكد أن عدم انتظام مواعيد المحاضرات

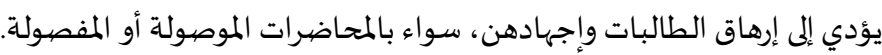

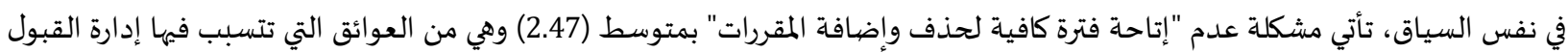

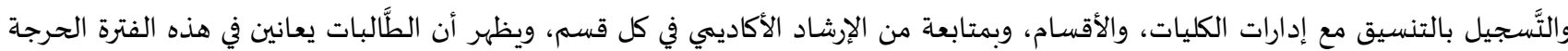

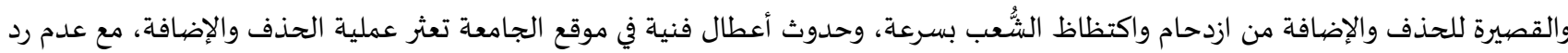

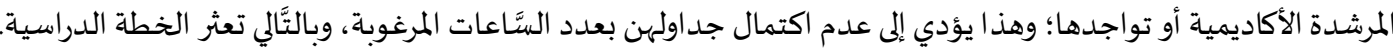

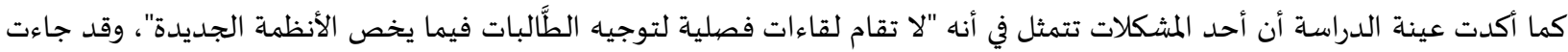

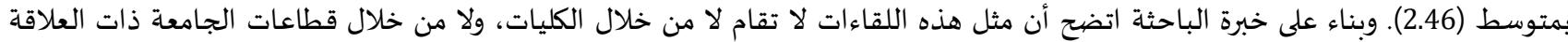

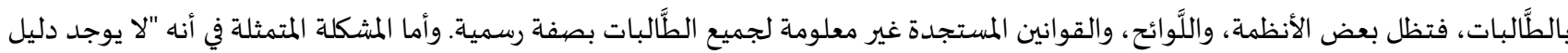

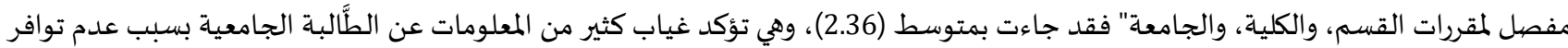

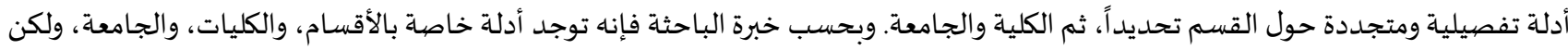

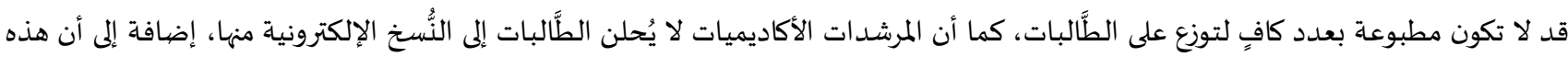

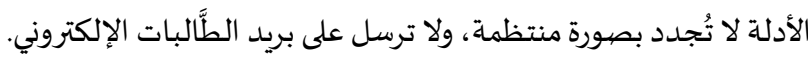

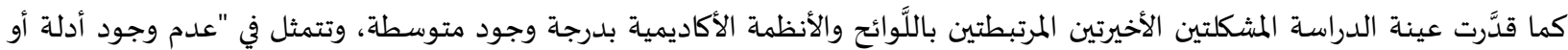

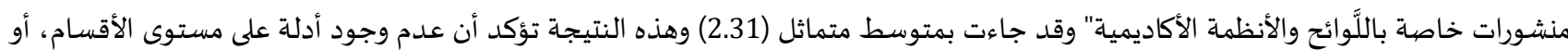

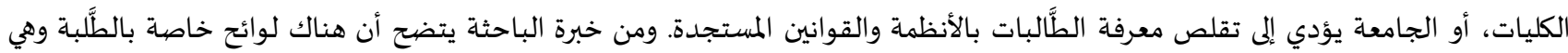

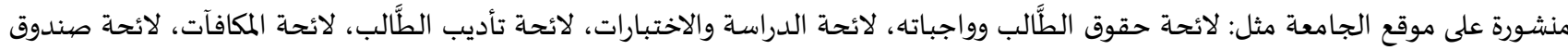

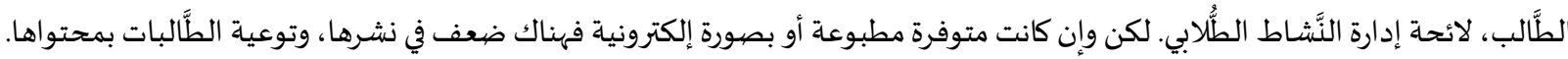

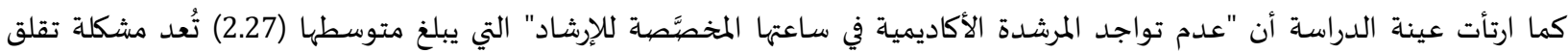

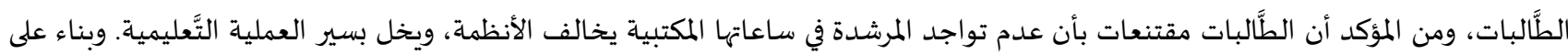

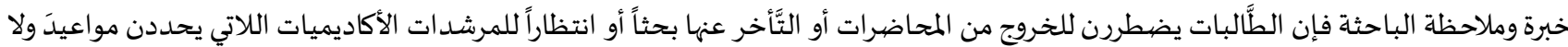

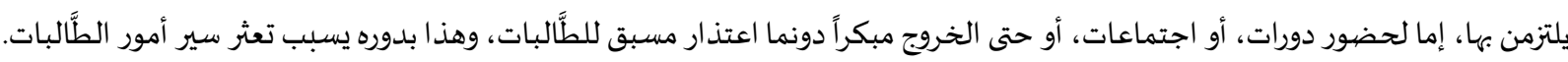

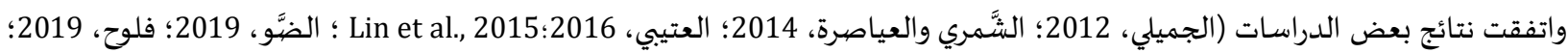
(Aladwan et al., 2019

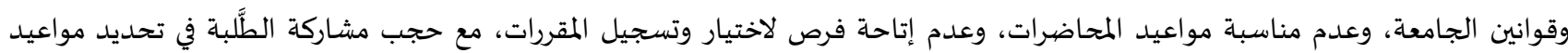
محاضراتهم بأنفسهم.

جدول (9): المتوسطات والانحر افات المعياربة لأبرز المشكلات الصيَّفية الجامعية لمحاور الاستبانة

\begin{tabular}{|c|c|c|c|c|c|}
\hline 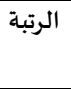 & الدَّرجة & المعياري & الحستابي & محاور استبانة المشككلات الصيَّفية الجامعية & م \\
\hline 1 & مرتفعة & 0.78 & 2.45 & المشكلات الصَّفية التي مصدرها اللَّوائح والأنظمة الأكاديمية & .1 \\
\hline 2 & متوسطة & 0.80 & 2.33 & المشككلات الصَّفية التي مصدرها المككونات النَّفس اجتماعية & .2 \\
\hline 3 & متوسطة & 0.81 & 2.32 & المشكلات الصَّفية التي مصدرها الأستاذ الجامعي & .3 \\
\hline 4 & متوسطة & 0.80 & 2.30 & المشكلات الصَّفية التي مصدرها المككونات الممادية & .4 \\
\hline 5 & متوسطة & 0.88 & 2.18 & المشكلات الصَّفية التي مصدرها الطَّالب & .5 \\
\hline
\end{tabular}

بالنَّظر إلى جدول رقم (9) يتضح أن المشكلات الصَّفية التي مصدرها اللَّوائح والأنظمة الأكاديمية جاءت في المرتبة الأولى بمتوسط (2.45) وهي

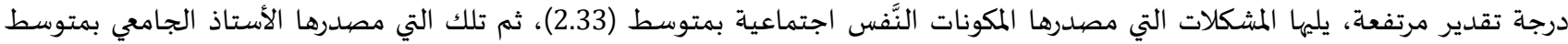

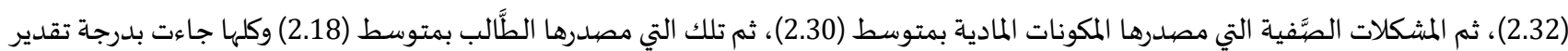

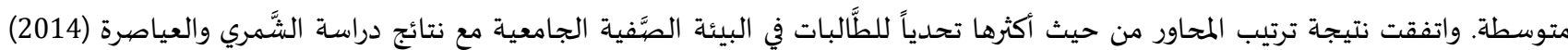

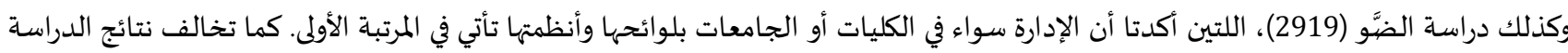

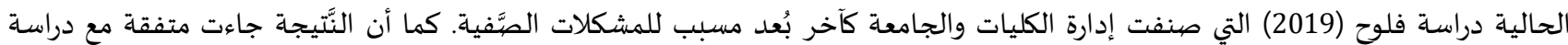

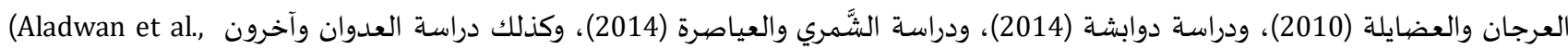

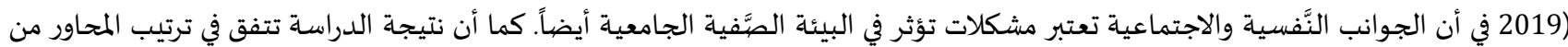

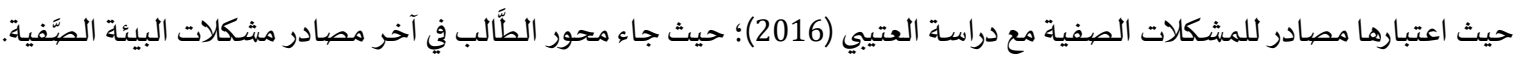


إجابة سؤال الدراسة السادس:

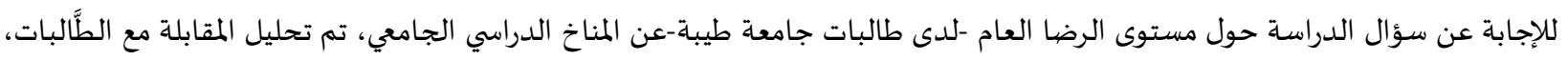

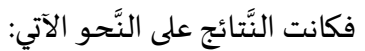

\begin{tabular}{|c|c|c|c|c|}
\hline المجموع الكلي & النسبة & التكرار & مستويات الرضا & م \\
\hline \multirow{3}{*}{$\begin{array}{c}2174 \\
(\% 100)\end{array}$} & $\% 15.7$ & 324 & راضِ جداً & .1 \\
\hline & $\% 57.1$ & 1242 & راضٍ نوعاً ما & .2 \\
\hline & $\% 27.1$ & 590 & غير راضٍ مطلقاً & .3 \\
\hline
\end{tabular}

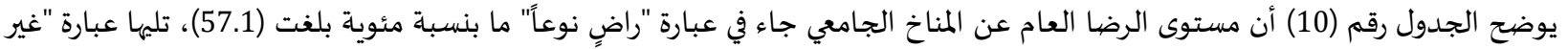

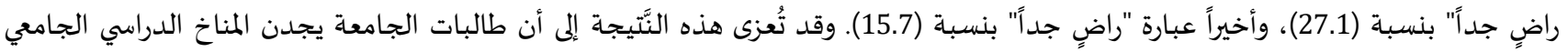

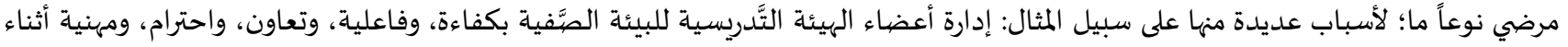

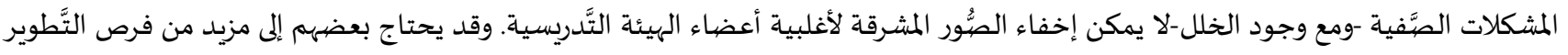

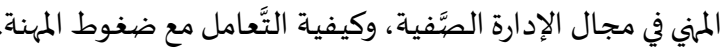

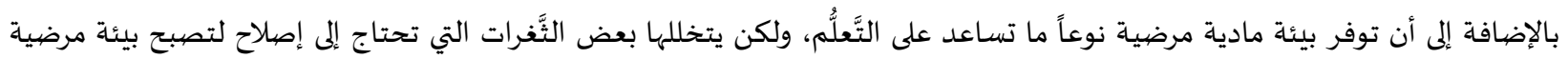

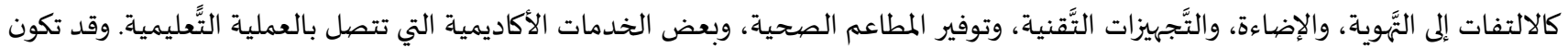

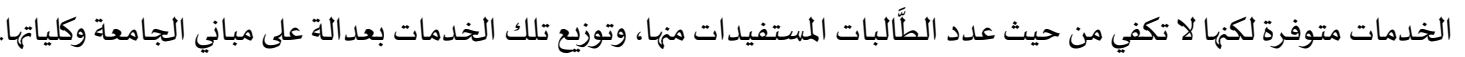

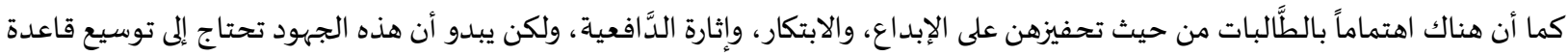

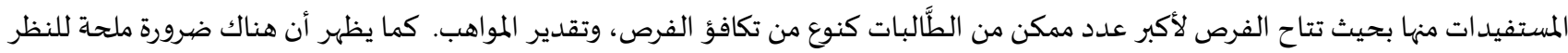

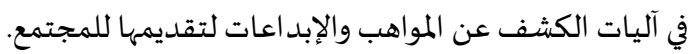

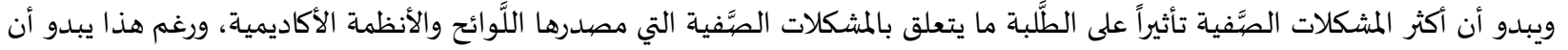

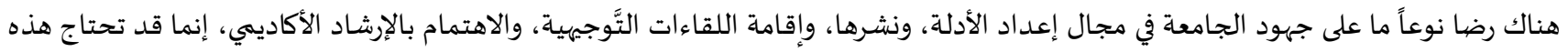
الخدمات إلى مزيد من الاهتمام من حيث النَّشر، والإعلان.

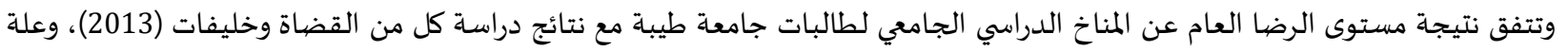

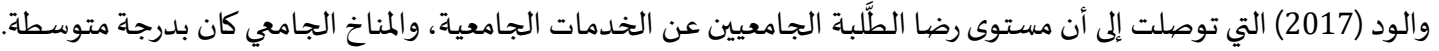

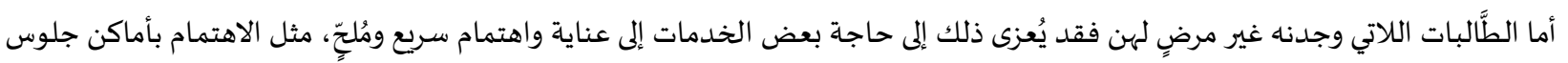

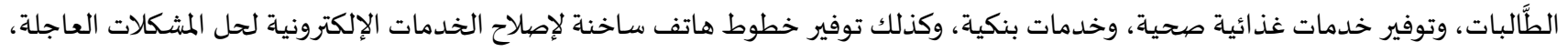

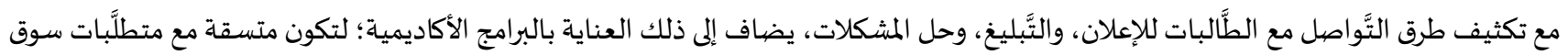

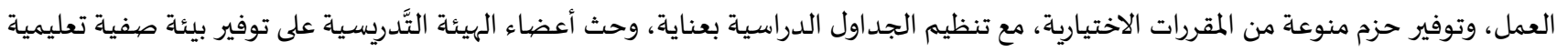

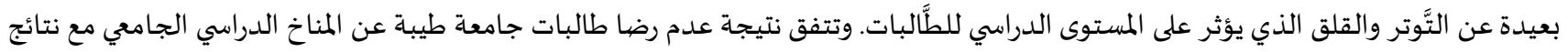

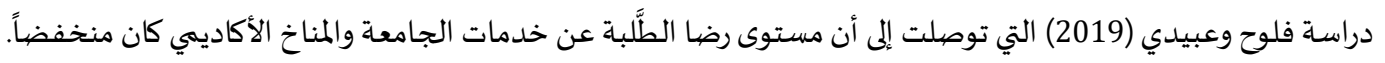

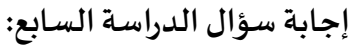

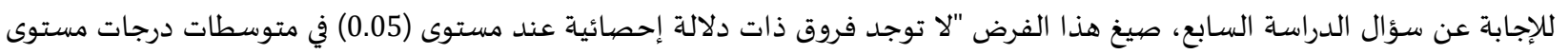

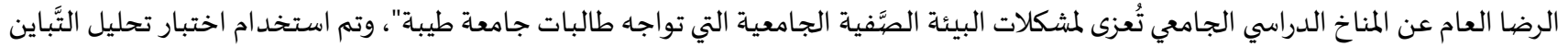

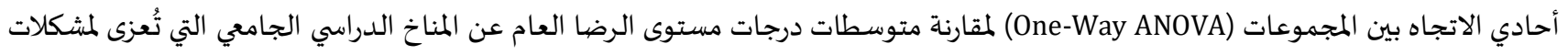

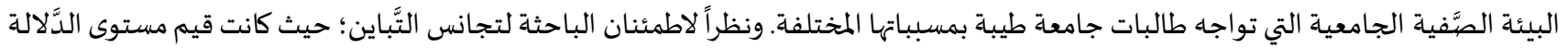

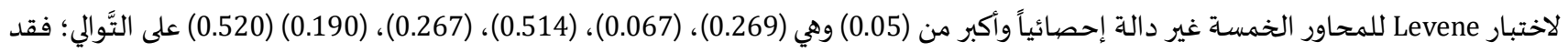
تم إجراء اختبار تحليل التَّباين، وكانت النَّائج كالتَّالي: 
جدول (11): المتوسطات والانحر افات المعيارية لمستوى الرضا العام عن المناخ الدراسي الجامعي تبعاً لمشكلات البيئة الصَّفية الجامعية

\begin{tabular}{|c|c|c|c|c|c|c|c|}
\hline \multicolumn{6}{|c|}{ مستوى الرضا العام عن المناخ الدراسي الجامعي } & \multirow[t]{3}{*}{ المشكلات الصيَفية في البيئة الجامعية } & \multirow[t]{3}{*}{ م } \\
\hline \multicolumn{2}{|c|}{ غير راضٍ مطلقاً } & \multicolumn{2}{|c|}{ راضٍٍ نوعاً ما } & \multicolumn{2}{|c|}{ راضٍ جداً } & & \\
\hline الانحراف & المتوسط & الانحراف & المتوسط & 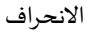 & المتوسط & & \\
\hline 7.16 & 46.76 & 7.49 & 45.82 & 7.48 & 47.90 & مشكلات صفية مصدرها الأستاذ الجامعي & .1 \\
\hline 6.72 & 21.60 & 6.53 & 21.99 & 6.22 & 21.74 & مشكلات صفية مصدرها الطَّلب & .2 \\
\hline 4.80 & 22.86 & 4.58 & 22.79 & 4.78 & 23.10 & مشكلات صفية مصدرها المكونات المادية & .3 \\
\hline 7.10 & 46.65 & 7.35 & 46.37 & 6.88 & 46.83 & مشكلات صفية مصدرها المككونات النَّفس اجتماعية & .4 \\
\hline 4.89 & 24.37 & 4.64 & 24.62 & 4.60 & 24.35 & مشكلات صفية مصدرها اللَّائح والأنظمة الآكاديمية & .5 \\
\hline
\end{tabular}

يتضح من الجدول أعلاه أن أعلى المتوسطات جاء لصالح المشكلات الصَّفية التي مصدرها الأستاذ الجامعي، وبدرجة (راضٍ جداً).

جدول (12): تحليل التَّباين أحادي الاتجاه بين متوسطات درجات مستوى الرضا العام عن المناخ الدراسي الجامعي ومشكلات البيئة الصيَّفية الجامعية

\begin{tabular}{|c|c|c|c|c|c|c|c|}
\hline معامل مريع & مستوى الدلالة & قيمة (ف) & متوسط المربعات & الحربة & مجموع المربعات & مصدر التَّباين & المشككلات الميَّفية في البيئة الجامعية \\
\hline \multirow[t]{2}{*}{0.011} & 0.000 & 11.543 & 632.10 & 2 & 1264.19 & بين المجموعات & مشكلات صفية مصدرها الأستاذ \\
\hline & & & 54.76 & 2171 & 118888.44 & داخل المجموعات & الجامعي \\
\hline \multirow[t]{2}{*}{--} & 0.473 & 0.750 & 31.99 & 2 & 63.99 & بين المجموعات & مشكلات صفية مصددرها الطَّالب \\
\hline & & & 42.68 & 2171 & 92658.89 & داخل المجموعات & \\
\hline \multirow[t]{2}{*}{--} & 0.549 & 0.599 & 13.10 & 2 & 26.19 & بين المجموعات & مشكلات صفية مصدرها المكونات \\
\hline & & & 21.86 & 2171 & 47464.17 & داخل المجموعات & المادية \\
\hline \multirow[t]{2}{*}{--} & 0.504 & 0.685 & 35.56 & 2 & 71.12 & بين المجموعات & مشكلات صفية مصدرها المكونات \\
\hline & & & 51.94 & 2171 & 112769.36 & داخل المجموعات & النَّس اجتماعية \\
\hline \multirow[t]{2}{*}{--} & 0.440 & 0.822 & 18.17 & 2 & 36.34 & بين المجموعات & مشكلات صفية مصدرها اللَّو ائح \\
\hline & & & 22.11 & 2171 & 48004.80 & داخل المجموعات & والأنظمة الأكاديمية \\
\hline
\end{tabular}

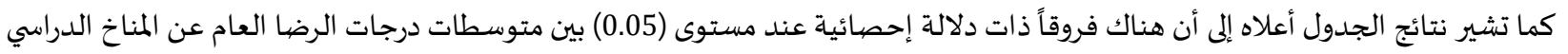

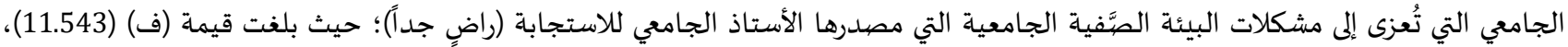

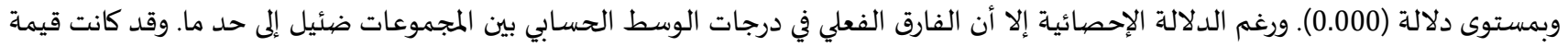

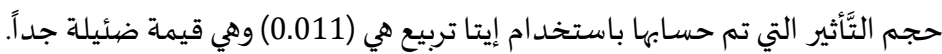

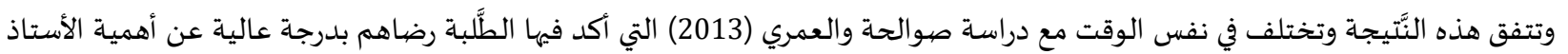
الجامعي لتحقيق الحاجات الأكاديمية للطُّلبة، وفي الوقت ذاته رصدد الطُّلبة درجة متوسطة لتحقق هذه الحاجات على أرض الواقع. كما تتفق هذه التها النَّتيجة مع دراسة كل من الضَّو (2019) ودراسة العدوان وآخرون (Aladwan et al., 2019) التي جاء فهيها ترتيب المشكلات المرتبطة بالأستاذ الجامعي

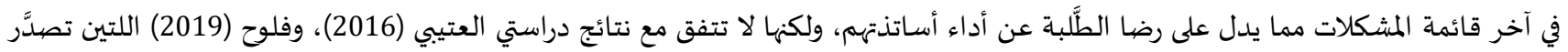

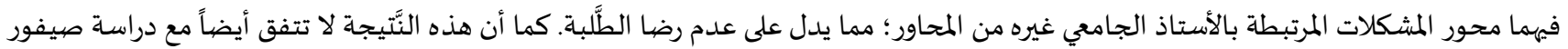

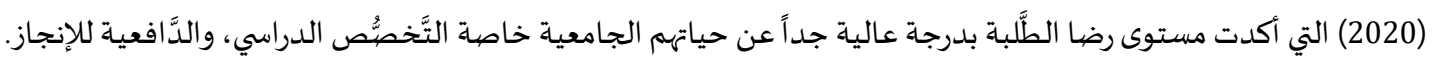

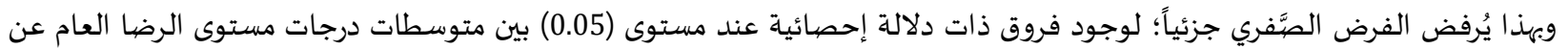

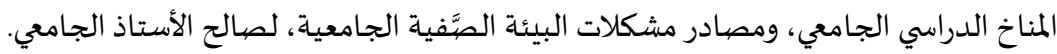
إجابة سؤال الدراسة الثامن:

للإجابة عن سؤال الدراسة الثامن حول أبرز التَّوصيات والمشكلات التي ترغب طالبات جامعادة طيبة في طرحها للنَّظر فهيا من قبل إدارة الجامعة

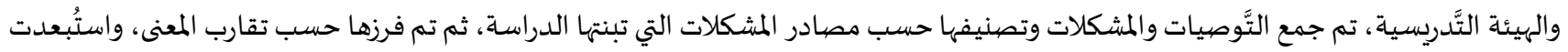

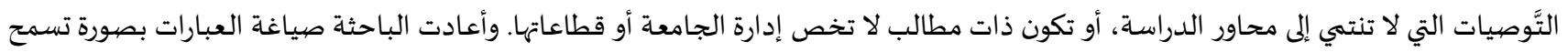

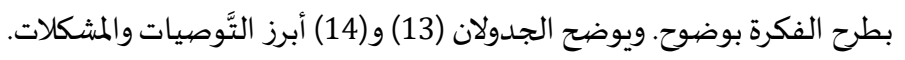




\begin{tabular}{|c|c|c|c|}
\hline 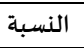 & 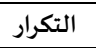 & التَّوصيات المقترحة & مجال المشكلات \\
\hline 23.53 & 24 & 1. استخدام طرق تدريس منوعة وحديثة. & توصيات تخص الأستاذ \\
\hline 12.75 & 13 & 2. تعاون أعضاء هيئة التَّدريس مع الطَّالبات والتَّخفيف عهن. & الجامعي \\
\hline 6.86 & 7 & 3. التزام الهيئة التَّدريسية بوضع الأسئلة من المنهج المقرر. & \\
\hline 1.96 & 2 & 4. تقييم المستوى العلمي لأعضاء هيئة التَّدريس. & \\
\hline 15.69 & 16 & 1. التَّعاون أثناء الأعمال الجماعية. & توصيات تخص الطًالب \\
\hline 12.75 & 13 & 2. الاهتمام بنظافة القاعات وأماكن الاستراحات. & الجامعي \\
\hline 11.76 & 12 & 3. احترام الغير وتقبل الآراء رغم الاختلاف. & \\
\hline 4.90 & 5 & 4. الانضباط الصَّفي للطَّالبات أثناء المحاضرات. & \\
\hline 1.96 & 2 & 5. التَّفاعل مع أعضاء هيئة التَّدربس في المحاضرات. & \\
\hline 25.49 & 26 & 1. الاهتمام بالتَّوية والتَكييف داخل القاعات. & توصيات تخص المكونات \\
\hline 24.51 & 25 & 2. الاهتمام بالتَّجهيزات التَّقنية داخل القاعات. & المادية \\
\hline 20.59 & 21 & 3. تغيير أماكن الكراسي وزيادة أعدادها وتنظيمها. & \\
\hline 14.71 & 15 & 4. الاهتمام بإضاءة القاعات بشكلٍ عاجلٍ. & \\
\hline 11.76 & 12 & 5. الاهتمام بالمرافق العامة (دورات المياه) في مباني الجامعة. & \\
\hline 5.88 & 6 & 6. وضع لوحات إرشادية في المباني الجامعية. & \\
\hline 28.43 & 29 & 1. التَّواصل الدَّائم والفعال مع الطَّالبات. & توصيات تخص المكونات \\
\hline 4.90 & 5 & 2. احترام أعضاء هيئة التَّدربس للطُّلبات. & النَّفس اجتماعية \\
\hline 4.90 & 5 & 3. ضممان حرية التَّعبير عن الرأي عند المشاركة. & \\
\hline 2.94 & 3 & 4. تحفيز الطُألبات المتميزات والموهوبات. & \\
\hline 15.69 & 16 & 1. توفير فعاليات مناسبة لطبيعة الطُألبات. & توصيات تخص اللَّو ائح \\
\hline 8.82 & 9 & 2. تقليل أوقات الفراغ بين المحاضرات. & والأنظمة الأكاديمية \\
\hline 2.94 & 3 & 3. تقليل عدد الطُّالبات في الشُّعب الدراسية. & \\
\hline
\end{tabular}

يعكس الجدول أعلاه المشككلات التي تواجه الطًالبات الجامعيات في صورة توصيات لتحسين البيئة الصَّفية الجامعية، وبالتَّدقيق في العبارات

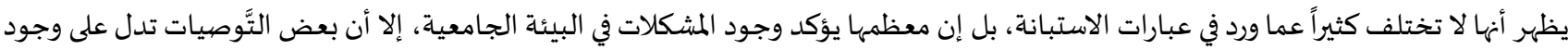

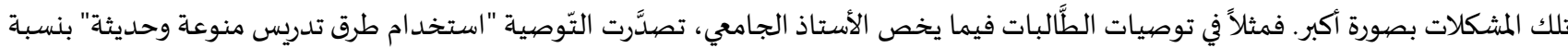

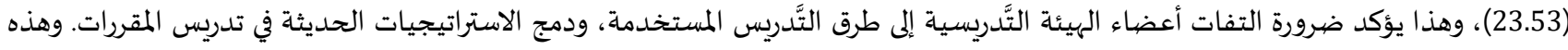

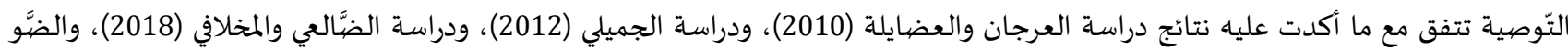
(2019) وكذلك دراسة صيفي وآخرون (Saifi et al., 2018)، وكذلك دراسة العدوان وآخرون (Aladwan et al., 2019).

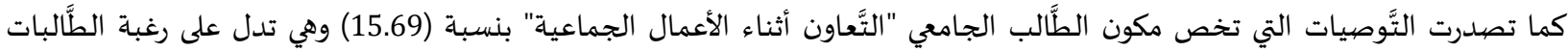

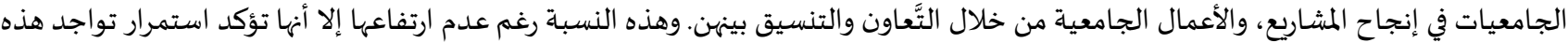

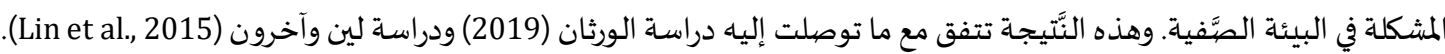

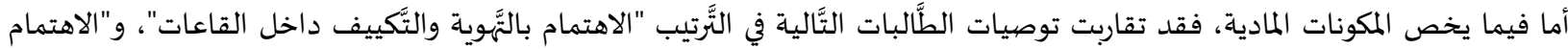

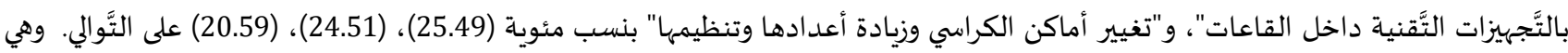

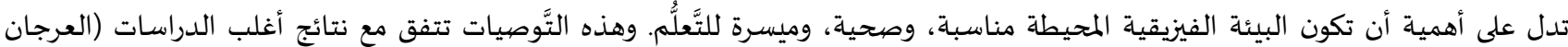

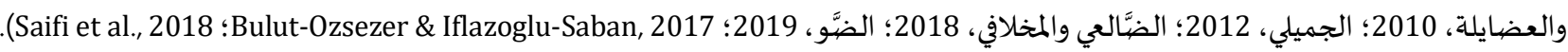
وفيما يخص توصيات الطُّالبات في محور المكونات النَّفس اجتماعية، تصدَّرت توصية "التَّواصل الدَّائم والفعَّال مع الطَّلَّلبات" بنسبة (28.43)

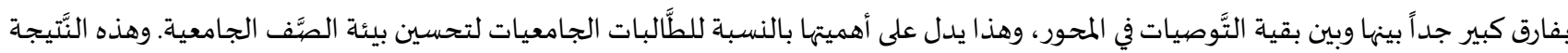

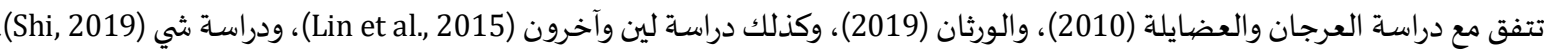

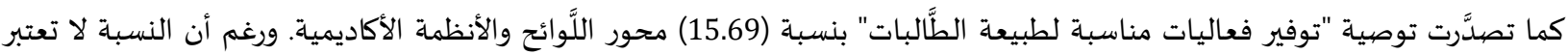

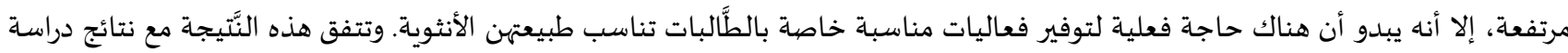
وصيفي وآخرون (Saifi et al., 2018)، ودراسة العدوان وآخرون (Aladwan et al., 2019).

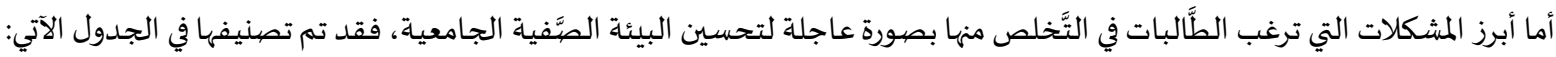




\begin{tabular}{|c|c|c|c|}
\hline النسبة & التكرار & أبرز المشكلات التي تستلزم تغييرات عاجلة & مجال المشكلات \\
\hline 16.67 & 17 & 1. اعتماد الأساتذة الكلي على الإلقاء في المحاضرات. & مشكلات عاجلة تخص \\
\hline 6.86 & 7 & 2. الأسئلة الموحدة في اختبارات المقررات. & الأستاذ الجامعي \\
\hline 5.88 & 6 & 3. كثرة الواجبات والأبحاث المطلوبة في كل مقرر. & \\
\hline 4.90 & 5 & 4. إلغاء المحاضرات العملية في المعامل رغم أهميتها. & \\
\hline 2.94 & 3 & 5. تغليب الجانب النَّظري على الجانب العملي في التَّعليم. & \\
\hline 19.61 & 20 & 1. عدم تحمل المسؤولية في الأعمال الجماعية. & مشكلات عاجلة تخص \\
\hline 11.76 & 12 & 2. عدم احترام الطَّالبات آراء بعضهن البعض. & الطًالب الجامعي \\
\hline 7.84 & 8 & 3. التَّنمر بجميع أشكاله على الزَّميلات. & \\
\hline 5.88 & 6 & 4. الإزعاج أثناء المحاضرات. & \\
\hline 28.43 & 29 & 1. عدم الاهتمام بالتَّهوية وضبط درجات الحرارة والبرودة. & مشكلات عاجلة تخص \\
\hline 26.47 & 27 & 2. عدم مناسبة مقاعد القاعات من حيث العدد والنَّوعية. & 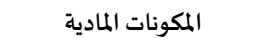 \\
\hline 16.67 & 17 & 3. سوء السبورات وأجهزة العرض. . & \\
\hline 12.75 & 13 & 4. ضيق بعض القاعات وعدم تنظيمها. & \\
\hline 11.76 & 12 & 5. عدم مناسبة الإضاءة في القاعات. & \\
\hline 11.76 & 12 & 1. التَّسلط المزعج من قبل بعض أعضاء هيئة التَّدريس. & مشكلات عاجلة تخص \\
\hline 7.84 & 8 & 2. الشُّخرية بالطًَّلبات والاستهزاء بهن وعدم احترامهن. & المكونات النَّفس اجتماعية \\
\hline 5.88 & 6 & 3. التَّحيُز لبعض الطُالبات لأسباب عديدة. & \\
\hline 12.75 & 13 & 1. عدم توفر خدمات أكاديمية كافية للطُالبات. & مشكلات عاجلة تخص \\
\hline 9.80 & 10 & 2. تكدس الطُألبات في الشُعب في معظم المقررات. & اللَّو ائح والأنظمة الأكاديمية \\
\hline 3.92 & 4 & 3. بُعد المباني بعضها عن بعض مع عدم وجود مواصلات. & \\
\hline 3.92 & 4 & 4. عدم توفر مطاعم صحية ذات جودة عالية. & \\
\hline
\end{tabular}

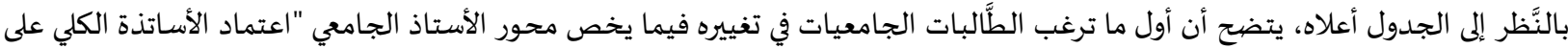

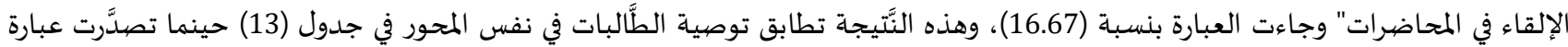

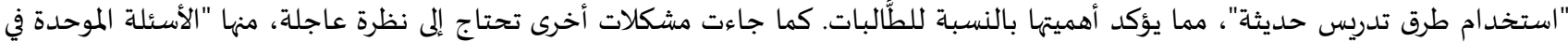

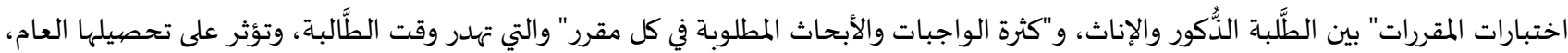

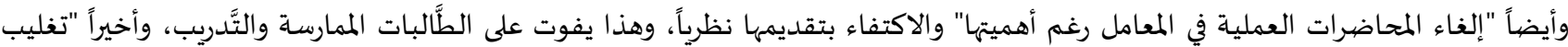

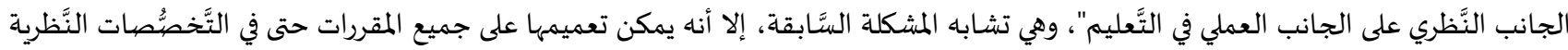

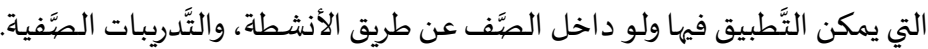

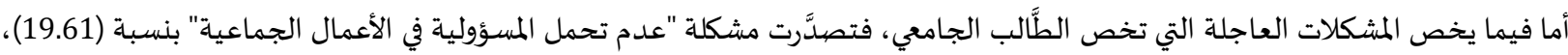

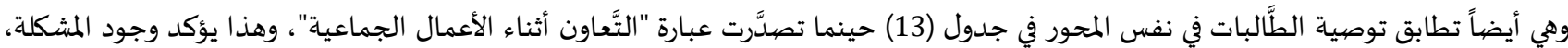

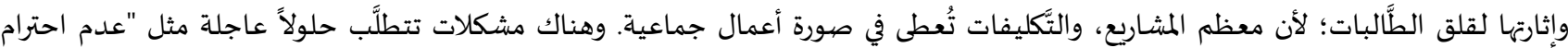

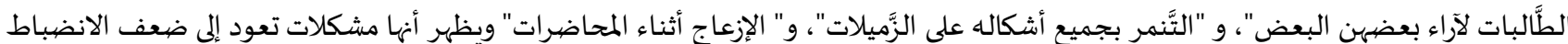

الصَّفي، وتؤكدها نتائج دراسة القحطاني وصببحا (2014).

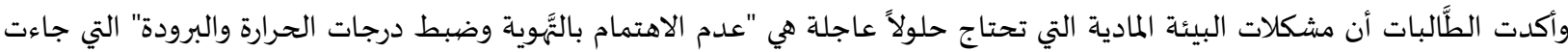
بنسبة (28.43)، و"عدم مناسبة مقاعد القاعات من حيث العدد والنَّعية" وجاءت بنسبة (26.47). وهذه المشكلات العاجلة الماتلة تتطابق مع التَّوصيات

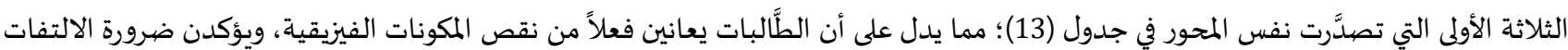

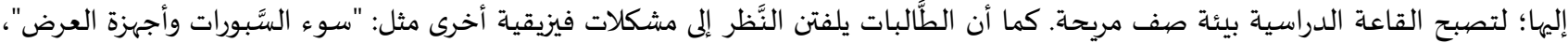

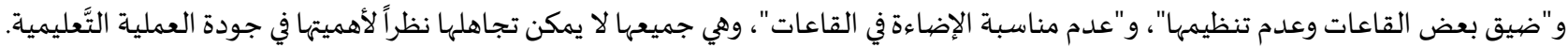

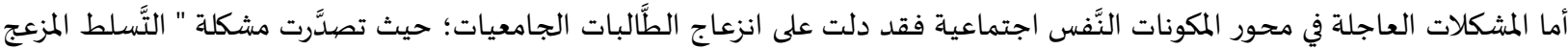

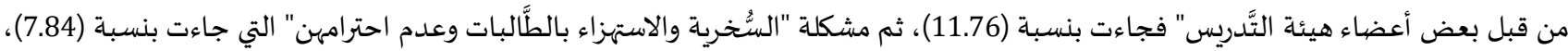

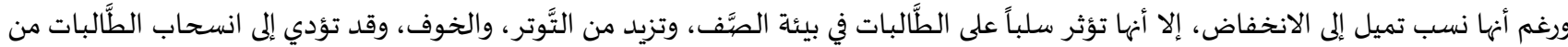

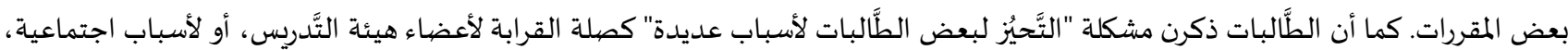

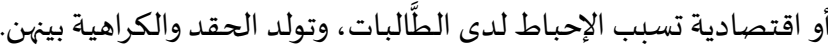

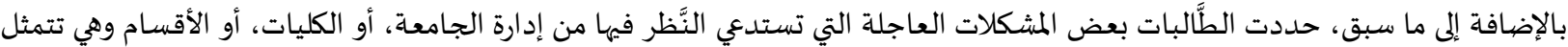

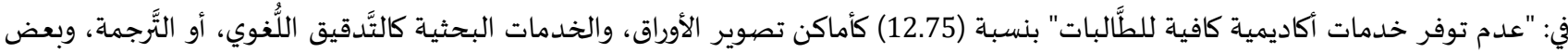




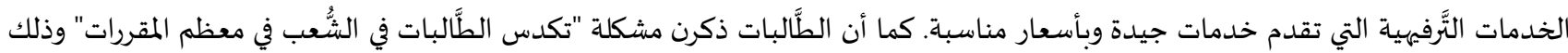

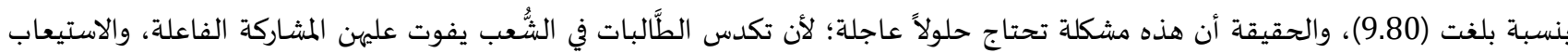

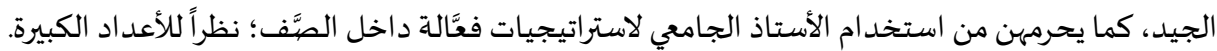

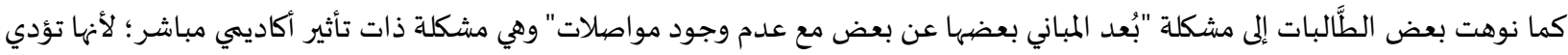

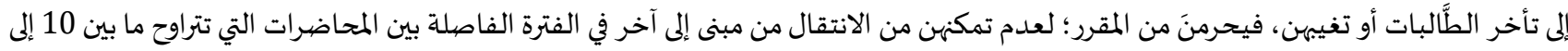

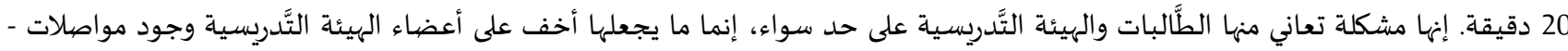
أحياناً داخل الجامعة مخصَّصة للانتقال بين مبانيها المتباعدة. وأخيراً، تجد الطُألبات أن "عدم توفر مطاعم صحية ذات جودة عالية" تُعد مشكلة عاجلة؛ لقناعهنن بأنه لا يوجد ما يمنع توفير مطاعم صحية

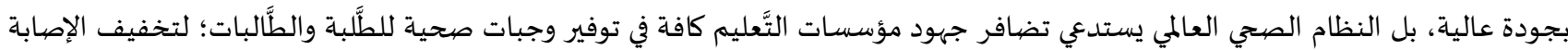

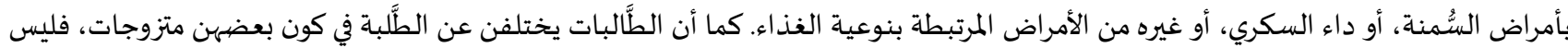

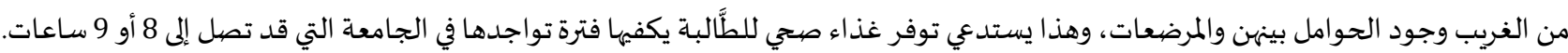

الخحاتمة والتَّوصيات والمقترحات: تودئ

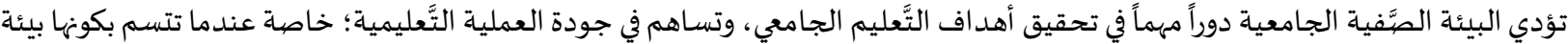

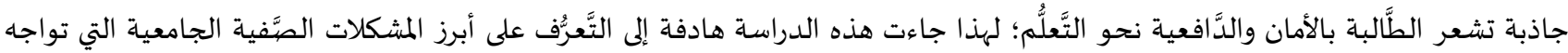

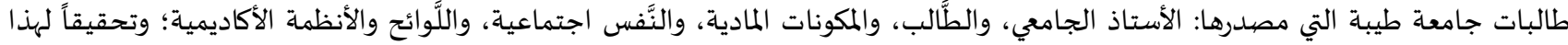

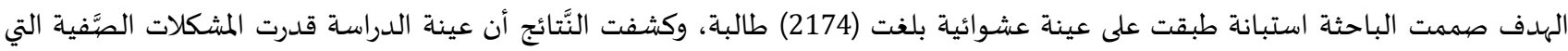

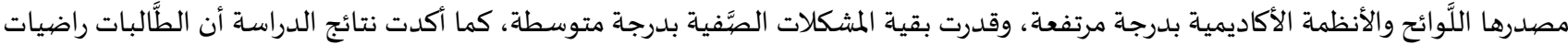

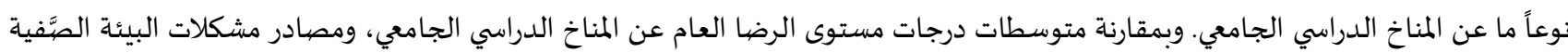

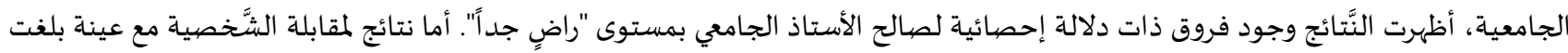

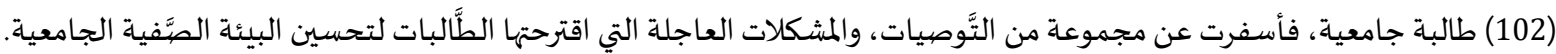

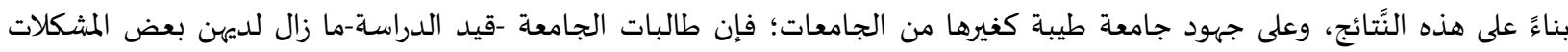

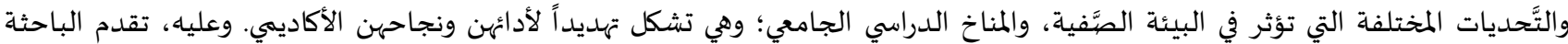

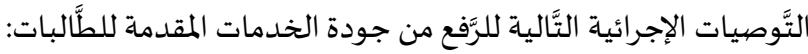

أولاً: توصيات متعلقة بالأستاذ الجامعي:

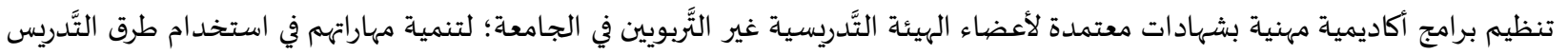
الحديثة التي تشجع التَّفكير، والابتكار، والحوار، والمناقشاة، وتجنب الأساليب التي تعتمد على الإلقاء.

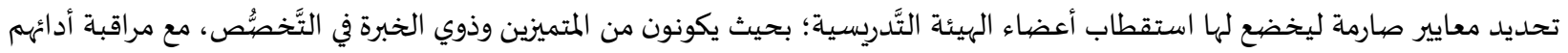

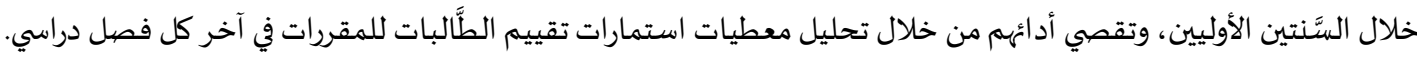
ثانياً: توصيات متعلقة بالطًّالب الجامعي: عقد دورات تدريبية بشكل متكرر تهدف إلى تهيئة الطُّالبات نفسياً واجتماعياً مع الحياة الجامعية، وتعزيز الثقة بالنَّف، مثل دورات: إدارة

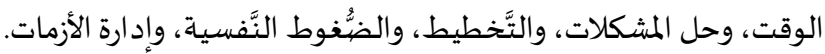

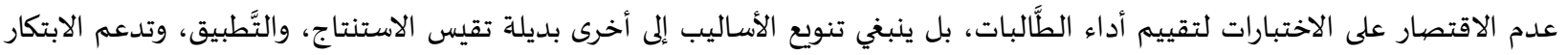

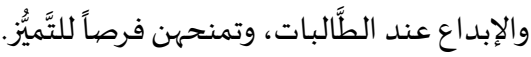

ثالثاً: توصيات متعلقة بالمكونات المادية: ضرورة التفات إدارة الجامعة إلى سرعة توفير الأجهزة التَّنية في القاعات، والوسائل السَّمعية والبصرية المناسبة، مع صيانة الموجود منها، وتجهيز الأدوات المعملية والمختبرية التي تيسر للطُّالبات العملية التَّكليمية.

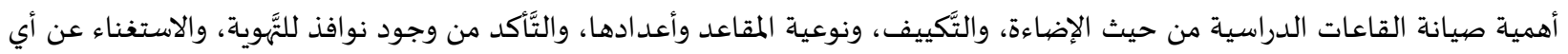
قاعات لا تتوفر فيها متطلَّبات البيئة الصَّفية الصحية. 
رابعاً: توصيات متعلقة بالمكونات النَّفس اجتماعية:

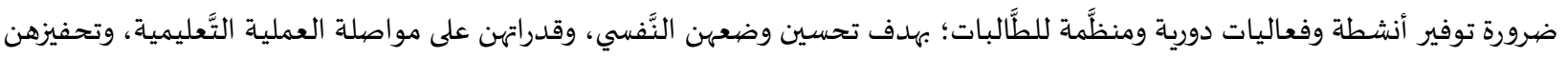

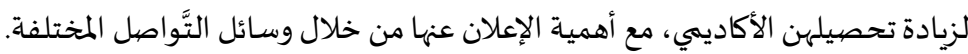

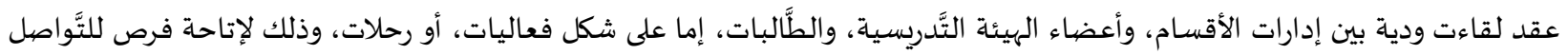
الفعَّال، ولتقريب وجهات النَّظر خارج القاعاة الدراسية.

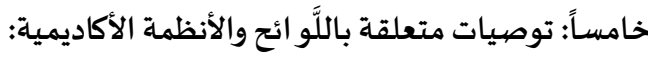
تخصيص اجتماعات فصلية تتضمن (لقاءً مفتوحاً مع عميد الكلية، ورؤساء الأقسام، والمختصين في القبول والتَّسجيل، وشؤون الطَّالبات)؛

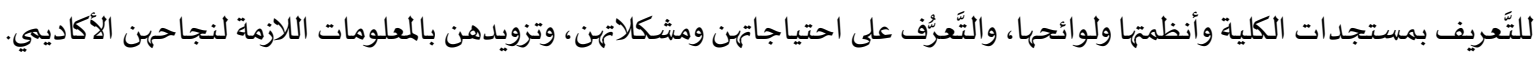
اختيار المرشدات من ذوات الخبرة في الإرشاد الأكاديمي، مع عقد دورات تدريبية لهن من قبل مركز الإرشاد في الجامعة، أو عمادة التَّطوير

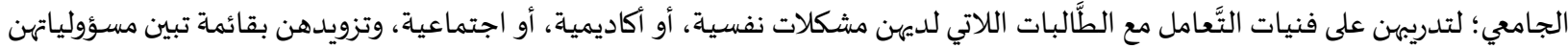
ومهامهن. ضهرورة مراجعة الكليات لتوصيفات برامجها الأكاديمية للتَّأكد من مناسبة المحتوى، وكذلك طرق التَّدريس المقترحة، وأساليب التَّقييم المقررة على الطًاّلبات، والاهتمام بنوعية الأنشطة المصاحبة للمقرورات الدراسية.

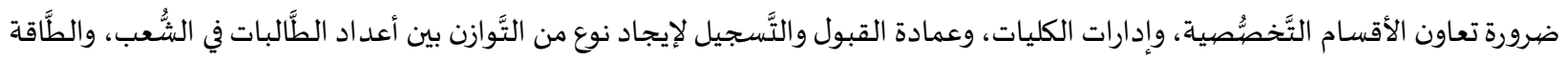

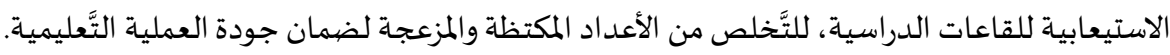
كما تقترح الدراسة الحالية إجراء دراسـات أخرى مثل:

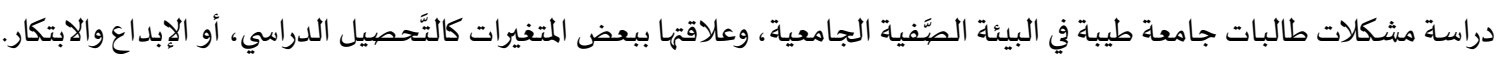
دراسة مشكلات طالبات جامعة طيبة في البيئة الصَّفية الجامعية من وجهاة نظر أعضياء الهيئة التَّدريسية. دراسة مماثلة كالدراسة الحالية على أن يتم تطبيقها على طالبات وطلبة جامعة طيبة، والمقارنة بين آرائهم.

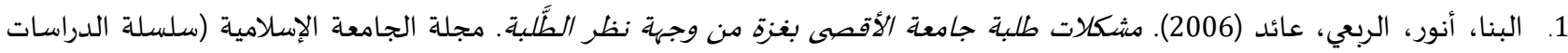
الإنسانية): 14 (2):

2. تمام، شادية؛ عفيفي، أميمة (2009). فعالية برنامج تدريبي مقترح لتنمية قدرات أعضاء هيئة التَّدرلس في ضهوء احتياجاتهم التَّلدربيية. بحث

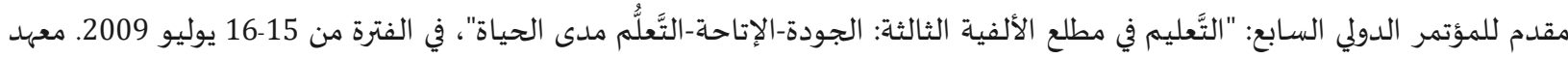

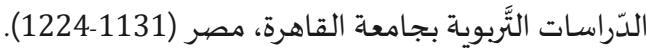
3. الجميلي، علي (2012). المشككلات الدراسية لدى طلبة جامعة الموصيل في ضهوء بعض المتغيرات. مجلة جامعة كركوك للدراسات الإنسانية، 7 (3)، 4 4. دوابشة، ليلى (2014). المشكلات السُّلوكية للدى طلبة الجامعة العربية الأمريكية من وجهة نظر أعضاء الهيئة التَّلدريسية. مجلة الجامعة العبية

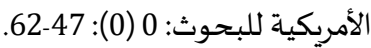

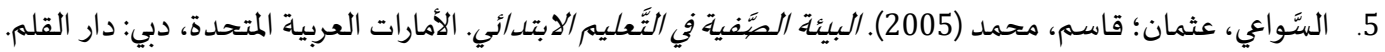

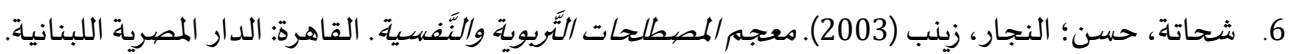

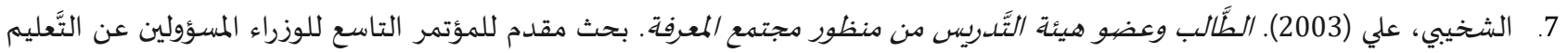
العالي والبحث العلمي في الوطن العربي (التَّعليم العالي والبحث العلمي في مجتمع المعرفة)، 15 - 18 ديسمبر. المنظمة العربية للتربية والثَّقافة والعلوم، دمشق (439-487). 8. الشَّمري، سعود؛ العياصرة، وليد (2014). المشككلات التي يواجهها طلاب البرامج التَّحضيلية بجامعة الإمام محمد بن سعود الإسلامية من وجهة نظرهم: دراسة ميدانية . مجلة العلوم الإنسانية والاجتماعية: 32: 15-62.

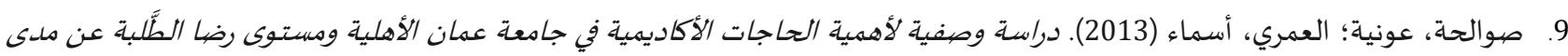
تحقق هنه الحاجات. مجلة الجامعة الإسلامية التَّبوية والنَّفسية: 21 (1): 401-447. 


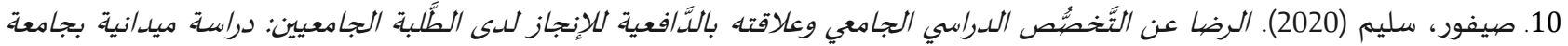

تاسوست جيجل. مجلة العلوم الإنسانية: 31 (1): 317-334.

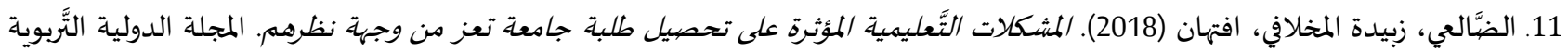

المتخصصية: 7 (8): $81-69$.

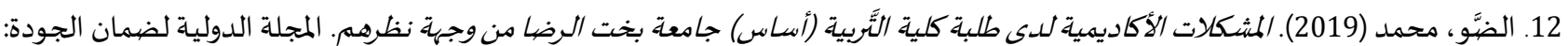

$.25-13:(1) 2$

13. ابن طريف، عاطف (2009). منظوهة مقترحة لتقويم أداء الإدارة الصَّفية في كليات التَّبية في ضوء معايير الإدارة الصَّفية الفعالة. مجلة كلية

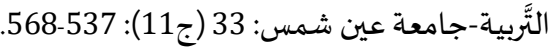

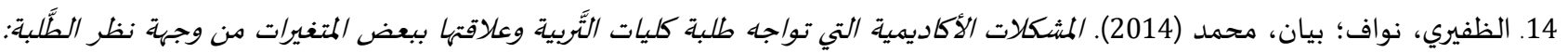

درابسة ميد/نية على طلبة قسم معلم الصَّفف في كلية التَّبية بجامعة البعث. مجلة اتحاد الجامعات العربية للتربية وعلم النَّفس: 12 (1): 70-90. 15. العتيبي، سعد (2016). المشكلات التي تواجه طلاب السنة الأولى بكليات محافظة عفيف وعلاقتها بمستوى الأداء الأكاديهي لهمر. مجلة كلية التَّبية-جامعة الأزهر: 170 (ج1)، 1 (1)

16. العرجان، جعفر؛ العضايلة، عدنان (2010). المشككلات التي يعاني منها طلبة جامعة البلقاء التَّطبيقية من وجهة نظهمه. مجلة أبحاث اليرموك

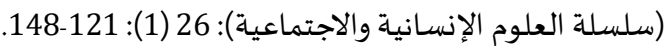

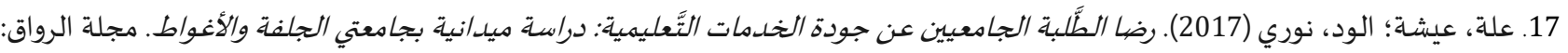
.31-5: 3

18. العمايرة، محمد؛ عشا، انتصار (2012). المشككلات الأكاديمية التي تواجه طلبة كلية العلوم الثَّوبوية والآد/ب الجامعية/ الأونروا-الأردن من وجهة

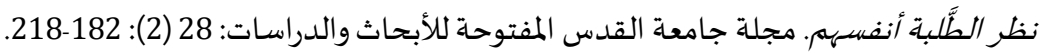

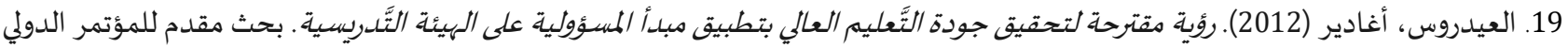

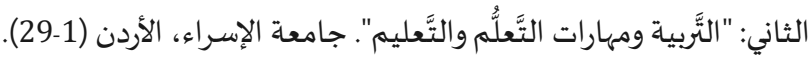

20. عيسى، هبة (2019).واقع المشككلات من وجهة نظر طلبة جامعة البصرة. المجلة الدولية للدراسات التَّبوية والنَّفسية: 6: 10-27.

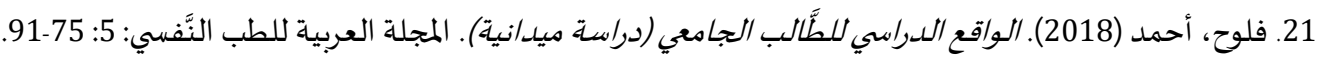

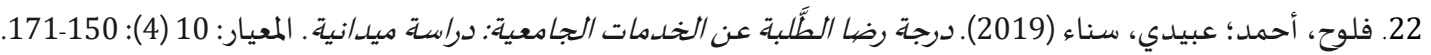

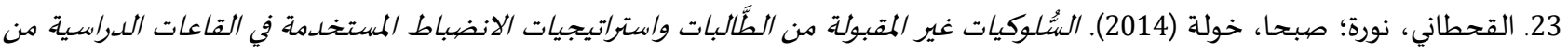

وجهة نظر عضوات هيئة التَّدريس في الأقسام الإنسانية والعلمية بجامعة الملك سعود. المجلة الدولية التَّبوية المتخصصية: 3 (6): 119-143. 24. القضاة، محمد؛ خلفات، عبد الفتاح (2013). درجة رضيا طلبة جامعة مؤتة عن الخدمات الجامعية من وجهة نظرهم. المنارة للبحوث والدراسات: 19 (1): 254-257.

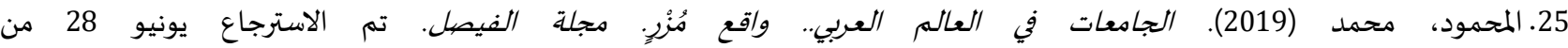
https://www.alfaisalmag.com/?p=14939 26. النَّجار، منى (2009). المشكلات الثَّبوية والأكاديمية والثَّقافية التي تواجه طلبة المستوى الرابع بكلية الثَّبية-جامعة الأزهر بغنة-المتدربين في مدارس محافظات غزة. مجلة جامعة الأزهر بغزة، سلسلة العلوم الإنسانية: 11 (2): 63-94.

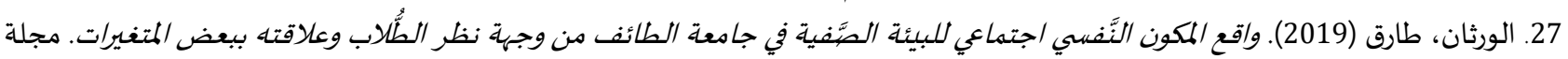

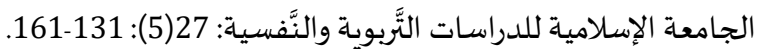

ثانياً: المراجع الأجنبية:

1. Aladwan, S., Aladwan, D., \& Alshiekh, M. (2019). The problems facing students at Al Ain University of Science and Technology. Journal of Engineering and Applied Sciences, 14 (7): 2212-2221, https://doi.org/10.36478/jeasci.2019.2212.2221.

2. Bolliger, D. \& Martindale, T. (2004). Key factors influencing student satisfaction with online courses. International Journal on E-Learning, 32(1): 61-67.

3. Bulut-Ozsezer, M. S., \& Iflazoglu-Saban, A. (2017). An Investigation of teacher candidates' perceptions about physical dimension of classroom management. European Journal of Educational Research,6(2): 199-212, https://doi.org/10.12973/eu-jer.6.2.199.

4. Djigic, G. \& Stojiljkovic, S. (2011). Classroom management styles, classroom climate and school achievement, Procedia Social and Behavioral Sciences, 29: 819 - 828, https://doi.org/10.1016/j.sbspro.2011.11.310. 
5. Lin, M., Pan, C., \& Ching, G. (2015). Common problems and coping solutions of university students in Taiwan. International Journal of Research Studies in Education, 4(1), 3-16, https://doi.org/10.5861/ijrse.2014.717.

6. Saifi, I., Hussain, M., Salamat, L., \& Bakht, M. (2018). Impact of classroom management on students' achievement at university level. Asian Innovative Journal of Social Sciences \& Humanities, 2(2): 13-27.

7. Shi, M. (2019). The effects of class size and instructional technology on student learning performance. The International Journal of Management Education, 17(1): 130-138, https://doi.org/10.1016/j.ijme.2019.01.004.

8. Shockley, D. (2005). Learning styles and students' perceptions of satisfaction in Community College web-based learning environments. Unpublished doctoral dissertation, the Graduate Faculty of North Carolina State University, Carolina.

9. Stone, V. (2006). Student satisfaction with and perceptions of relationship development in counselor education videoconferencing courses. Unpublished doctoral dissertation, the faculty of the Virginia Polytechnic Institute and State University, Falls Church, Virginia.

10. Sun, R. (2015). Teachers' experiences of effective strategies for managing classroom misbehavior in Hong Kong. Teaching and Teacher Education, 46: 94-103, https://doi.org/10.1016/j.tate.2014.11.005. 
المجلة الدولية للدراسـات التربوية والنفسية

International Journal of Educational \& Psychological Studies (EPS)

Journal Homepage: https://www.refaad.com/views/EPSR/Home.aspx

www.refaad.com

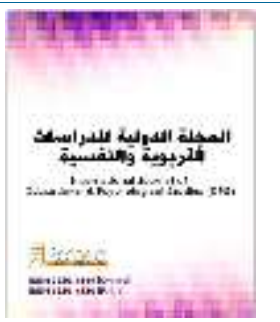

\title{
Classroom environment problems facing Taibah university female students and their relationship to the overall level of satisfaction with the university academic climate
}

\author{
Hayat Rasheed Hamzah Alamri \\ Associate Professor of TEFL, College of Education, Taibah University, KSA \\ hayatalamri@hotmail.com
}

Received : 11/7/2020 Revised : 22/7/2020 Accepted : 1/8/2020 DOI : https://doi.org/10.31559/EPS2021.9.2.9

Abstract: The study aimed to identify university classroom problems facing Taibah University female students and explore the differences between the average scores for the overall level of satisfaction with the university academic climate that are attributable to these problems. In addition, it tends to discover the most important recommendations and prominent defects that should be reconsidered urgently. A questionnaire that consisted of 5 dimensions and (68) items was designed. A sample of (2174) students was randomly chosen, during the $2^{\text {nd }}$ semester of the 2020 academic year. The results revealed that academic regulations and systems problems came in a high degree and with an average of (2.45). Moreover, the students' overall level of satisfaction indicated "somewhat satisfied" with a ratio of (57.1\%). As well, there were statistically significant differences at the level (0.05) between the overall satisfaction levels in favor of the university professor at a rank of "very satisfied". The results of the interview with a sample of (102) students resulted in a set of recommendations and urgent problems proposed by the students to improve the university classroom environment.

Keywords: Classroom Environment Problems; Level of Satisfaction; the Academic University Climate.

\section{References:}

1. 'Ih, 'yshh; Alwd, Nwry (2017). Rda Altlbh Aljam'yyn 'n Jwdh Alkhdmat Alt'lymyh: Drash Mydanyh Bjam'ty Aljlfh Walaghwat. Mjlt Alrwaq: 3 (1): 5-31.

2. Al'mayrh, Mhmd;'sha, Antsar (2012). Almshklat Alakadymyh Alty Twajh Tlbh Klyt Al'lwm Altŕbwyh Waladab Aljam'yh/ Alawnrwa-Alardn Mn Wjht Nzr Altlbh Anfshm. Mjlt Jam't Alqds Almftwhh Llabhath Waldrasat: 28 (2): 182-218.

3. Al'rjan, J'fr; Al'daylh, 'dnan (2010). Almshklat Alty Y'any Mnha Tlbh Jam't Alblqa' Alttbyqyh Mn Wjht Nzrhm. Mjlt Abhath Alyrmwk (Slslh Al'Iwm Alensanyh Walajtma'yh): 26 (1): 121-148.

4. Al'tyby, S'd (2016). Almshklat Alty Twajh Tlab Alsnh Alawla Bklyat Mhafzh 'fyf W'laqtha Bmstwa Alada' Alakadymy Lhm. Mjlt Klyt Altrbyh-Jam't Alazhr: 170 (J1), 711-749.

5. Al'ydrws, Aghadyr (2012). R'yh Mqtrhh Lthqyq Jwdh Alt'lym Al'aly Bttbyq Mbda Alms'wlyh 'la Alhy'h Altdrysyh. Bhth Mqdm Llm'tmr Aldwly Althany: "Altrbyh Wmharat Alt'lum Walt'lym". Jam't Alesra', Alardn (1-29).

6. 'ysa, Hbh (2019). Waq' Almshklat Mn Wjht Nzr Tlbh Jam't Albsrh. Almjlh Aldwlyh Lldrasat Altrbwyh Walnf́syh: 6: 10-27.

7. Albna, Anwr, Alrb'y, 'a'd (2006). Mshklat Tlbt Jam't Alaqsa Bghzh Mn Wjht Nzr Altlbh. Mjlt Aljam'h Aleslamyh (Slslt Aldrasat Alensanyh): 14 (2): 505-537.

8. Aldal'y, Zbydh Almkhlafy, Afthan (2018). Almshklat Alt'lymyh Alm'thrh 'la Thsyl Tlbh Jam't T'ez Mn Wjht Nzrhm. Almjlh Aldwlyh Altrbwyh Almtkhssh: 7 (8): 69-81.

9. Aldw, Mhmd (2019). Almshklat Alakadymyh Lda Tlbt Klyt Altrbyh (Asas) Jam't Bkht Alrda Mn Wjht Nzrhm. Almjlh Aldwlyh Ldman Aljwdh: 2 (1): 13-25. 
10. Dwabshh, Lyla (2014). Almshklat Alsulwkyh Lda Tlbh Aljam'h Al'rbyh Alamrykyh Mn Wjhh Nzr A'da' Alhy'h Altdrysyh. Mjlt Aljam'h Al'rbyh Alamrykyh Llbhwth: 0 (0): 47-62.

11. Flwh, Ahmd (2018). Alwaq' Aldrasy Lltálb Aljam'y (Drash Mydanyh). Almjlh Al'erbyh Lltb Alnfsy: 5: 75-91.

12. Flwh, Ahmd; 'bydy, Sna' (2019). Drjt Rda Altlbh 'n Alkhdmat Aljam'yh: Drash Mydanyh. Alm'yar: 10 (4): 150-171.

13. Aljmyly, 'ly (2012). Almshklat Aldrasyh Lda Tlbt Jam't Almwsl Fy Dw' B'd Almtghyrat. Mjlh Jam't Krkwk Lldrasat Alensanyh, 7 (3), 1-24.

14. Almhmwd, Mhmd (2019). Aljam'at Fy Al'alm Al'rby.. Waq' Muzion. Mjlt Alfysl. Tm Alastrja' Ywnyw 28 Mn https://www.alfaisalmag.com/?p=14939

15. Alnjar, Mna (2009). Almshklat Altrbwyh Walakadymyh Walthq́afyh Alty Twajh Tlbt Almstwa Alrab' Bklyh Altrbyh-Jam't Alazhr Bghzh-Almtdrbyn Fy Mdars Mhafzat Ghzh. Mjlt Jam't Alazhr Bghzh, Slslt Al'lwm Alensanyh: 11 (2): 63-94.

16. Alqdah, Mhmd; Khlfat, 'bd Alftah (2013). Drjh Rda Tlbh Jam't M'th 'n Alkhdmat Aljam'yh Mn Wjht Nzrhm. Almnarh Llbhwth Waldrasat: 19 (1): 257-294.

17. Alqhtany, Nwrh; Sbha, Khwlh (2014). Alsulwkyat Ghyr Almqbwlh Mn Altalbat Wastratyjyat Alandbat Almstkhdmh Fy Alqa'at Aldrasyh Mn Wjht Nzr 'dwat Hy't Altdrys Fy Alaqsam Alensanyh Wal'elmyh Bjam't Almlk S'wd. Almjlh Aldwlyh Altrbwyh Almtkhssh: 3 (6): 119-143.

18. Shhath, Hsn; Alnjar, Zynb (2003). M'jm Almstlhat Altrbwyh Walnf́syh. Alqahrh: Aldar Almsryh Allbnanyh.

19. Alshkhyby, 'ly (2003). Altálb W'dw Hy't Altdrys Mn Mnzwr Mjtm' Alm'rfh. Bhth Mqdm Llm'tmr Altas' Llwzra' Alms'wlyn 'n Alt'lym Al'aly Walbhth Al'lmy Fy Alwtn Al'rby (Alt'lym Al'aly Walbhth Al'lmy Fy Mjtm' Alm'rfh), 15 - 18 Dysmbr. Almnzmh Al'rbyh Lltrbyh Walthquafh Wal'lwm, Dmshq (439-487).

20. Alshmry, S'wd; Al'yasrh, Wlyd (2014). Almshklat Alty Ywajhha Tlab Albramj Althdyryh Bjam't Alemam Mhmd Bn S'wd Aleslamyh Mn Wjht Nzrhm: Drash Mydanyh. Mjlt Al'lwm Alensanyh Walajtma'yh: 32: 15-62.

21. Swalhh, 'wnyh;Al'mry, Asma' (2013). Drash Wsfyh Lahmyh Alhajat Alakadymyh Fy Jam't 'man Alahlyh Wmstwa Rda Altlbh 'n Mda Thqq Hdt Alhajat. Mjlt Aljameh Aleslamyh Altrbwyh Walnf́syh: 21 (1): 401-447.

22. Alswa'y, 'thman؛ Qasm, Mhmd (2005). Alby'h Alsfyh Fy Alt'lym Alabtda'y. Alamarat Al'rbyh Almthdh, Dby: Dar Alqlm.

23. Syfwr, Slym (2020). Alrda 'n Altkhsus Aldrasy Aljam'y W'laqth Baldáf'yh Llenjaz Lda Altlbh Aljam'yyn: Drash Mydanyh Bjam't Taswst Jyjl. Mjlt Al'lwm Alensanyh: 31 (1): 317-334.

24. Tmam, Shadyh; 'fyfy, Amymh (2009). F'alyt Brnamj Tdryby Mqtrh Ltnmyh Qdrat A'da' Hy't Altdrys Fy Dw' Ahtyajathm Altdrybyh. Bhth Mqdm Llm'tmr Aldwly Alsab': "Alt'lym Fy Mtl' Alalfyh Althalthh: Aljwdh-Aletahh-Alt'lum Mda Alhyah", Fy Alftrh Mn 15-16 Ywlyw 2009. M'hd Aldrasat Altrbwyh Bjam't Alqahrh, Msr (1131-1224).

25. Abn Tryf, 'atf (2009). Mnzwmh Mqtrhh Ltqwym Ada' Aledarh Alsfyh Fy Klyat Altrbyh Fy Dw' M'ayyr Aledarh Alsfyh Alf'alh. Mjlt Klyt Altrbyh-Jam't 'yn Shms: 33 (J11): 537-568.

26. Alwrthan, Tarq (2019). Waq' Almkwn Alnfsy Ajtma'y Llby'h Alsfyh Fy Jam't Alta'f Mn Wjht Nzr Altulab W'laqth Bb'd Almtghyrat. Mjlt Aljam'h Aleslamyh Lldrasat Altrbwyh Walnfsyh: 27(5): 131-161.

27. Alzfyry, Nwaf; Byan, Mhmd (2014). Almshklat Alakadymyh Alty Twajh Tlbt Klyat Altrbyh W'laqtha Bb'd Almtghyrat Mn Wjhh Nzr Altlbh: Drash Mydanyh 'la Tlbt Qsm M'Im Alsf Fy Klyt Altrbyh Bjam't Alb'th. Mjlt Athad Aljam'at Al'rbyh Lltrbyh W'lm Alnfs: 12 (1): 70-90. 